
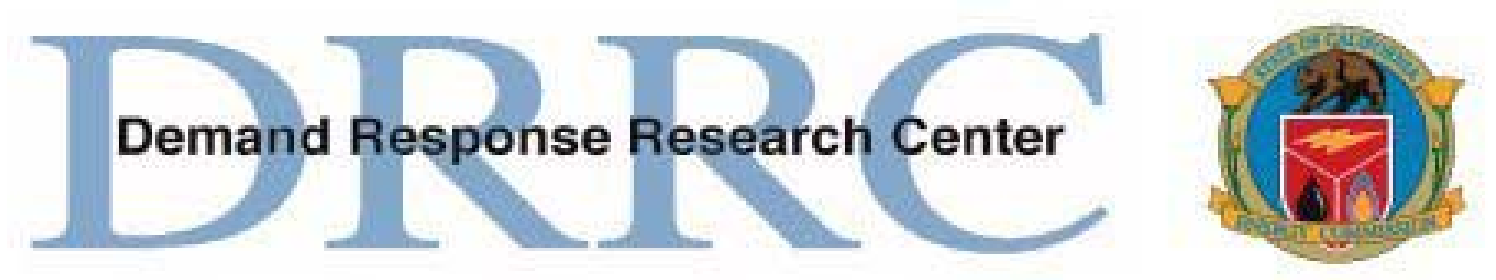

\title{
Automated Critical Peak Pricing Field Tests: Program Description and Results
}

\author{
April 6, 2006 \\ Mary Ann Piette \\ David Watson \\ Naoya Motegi \\ Sila Kiliccote \\ Peng Xu
}

Lawrence Berkeley National Laboratory

Sponsored by the Pacific Gas and Electric Company

Emerging Technologies Program

California Institute for Energy and the Environment

LBNL Report Number 59351 


\section{DISCLAIMER}

This document was prepared as an account of work sponsored by the United States Government. While this document is believed to contain correct information, neither the United States Government nor any agency thereof, nor The Regents of the University of California, nor any of their employees, makes any warranty, express or implied, or assumes any legal responsibility for the accuracy, completeness, or usefulness of any information, apparatus, product, or process disclosed, or represents that its use would not infringe privately owned rights. Reference herein to any specific commercial product, process, or service by its trade name, trademark, manufacturer, or otherwise, does not necessarily constitute or imply its endorsement, recommendation, or favoring by the United States Government or any agency thereof, or The Regents of the University of California. The views and opinions of authors expressed herein do not necessarily state or reflect those of the United States Government or any agency thereof, or The Regents of the University of California.

This report was prepared as a result of work sponsored by the California Energy Commission (Commission). It does not necessarily represent the views of the Commission, its employees, contractors, and subcontractors make no warranty, express or implied, and assume no legal liability for the information in this report; nor does any party represent that the use of this information will not infringe upon privately owned rights. This report has not been approved or disapproved by the Commission nor has the Commission passed upon the accuracy or adequacy of the information in this report.

The research reported here was funded by Pacific Gas and Electric and the California Institute for Energy Efficiency (CIEE), a research unit of the University of California, under CIEE/PG\&E Contract PGZ-0501. This work was also supported by the Assistant Secretary for Energy Efficiency and Renewable Energy, Office of Building Technology, Building Technology Programs of the U.S. Department of Energy under Contract No. DE-AC02-05CH11231. 


\section{Table of Contents}

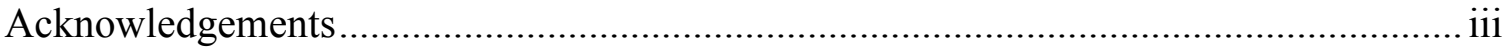

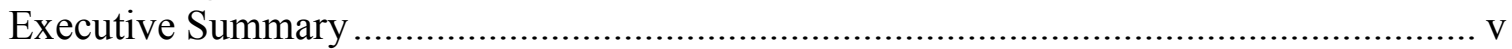

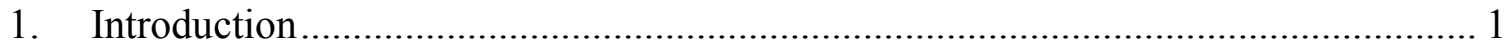

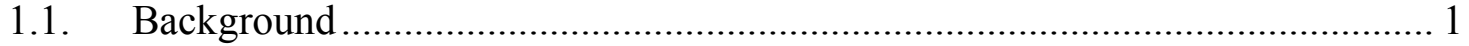

1.2. Goals and Objectives of Automated CPP ..................................................... 4

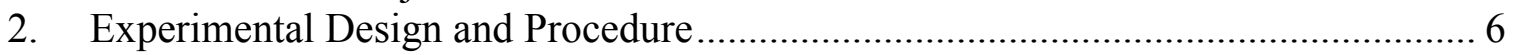

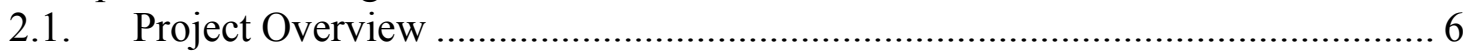

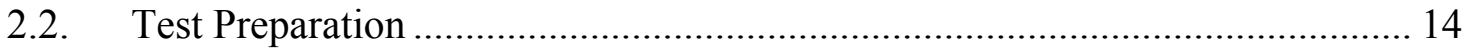

2.3. Automated Demand Response System Description .................................... 14

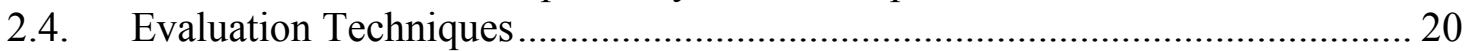

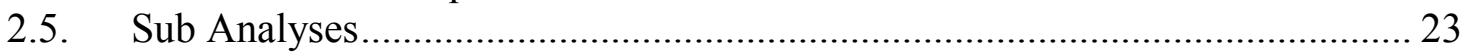

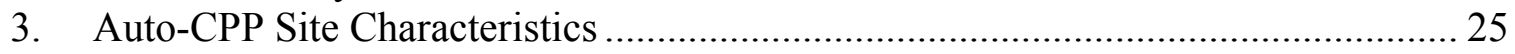

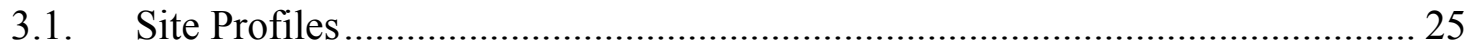

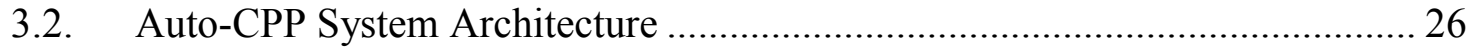

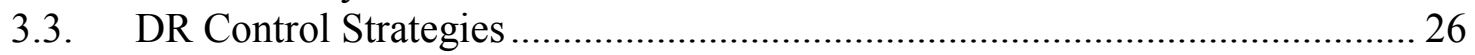

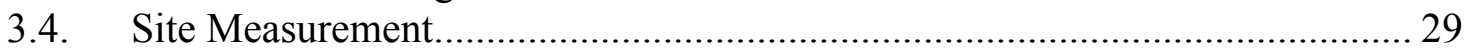

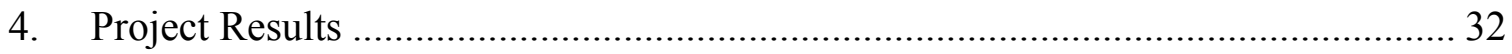

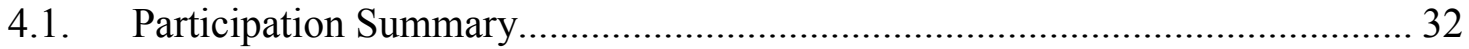

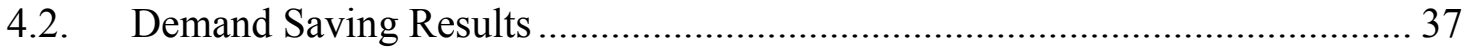

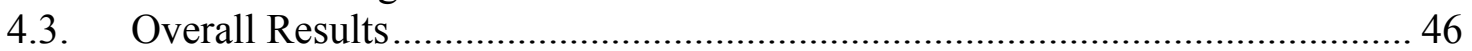

4.4. Incremental Cost for Materials and Installation............................................... 47

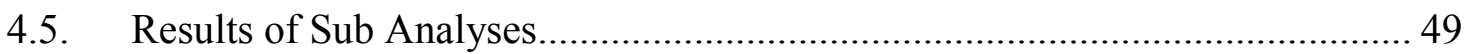

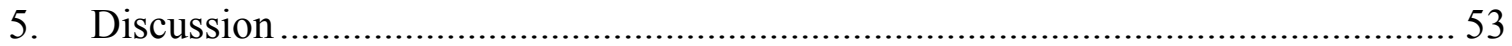

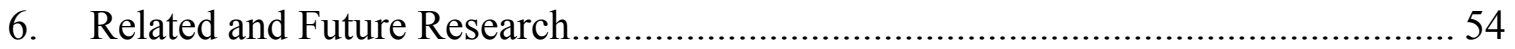

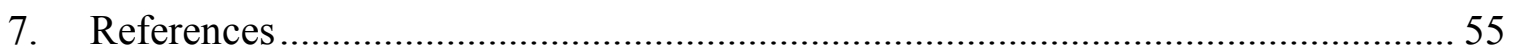

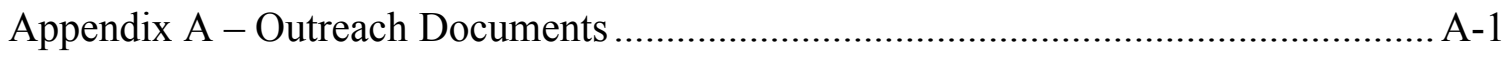

Appendix B - Site Descriptions \& Demand Response Details ................................ B-1

Appendix C - Post Test Survey Notes.................................................................

\section{List of Figures}

Figure E-1: Automated CPP Aggregated Demand Saving Results, September $29^{\text {th }} \ldots . .$. viii

Figure 2-1: PG\&E Critical Peak Pricing Tariff Structure .............................................. 7

Figure 2-2: Demand Response Automation Server Web Interface ............................... 15

Figure 2-3: Auto-CPP Control and Communication System Architecture........................ 18

Figure 2-4: Whole-Building Baseline Time-Series Chart .............................................. 22

Figure 4-1: Auto-CPP Control and Communication System Architecture....................... 36

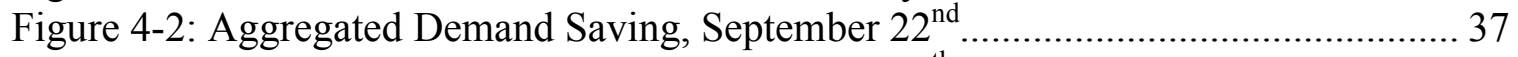

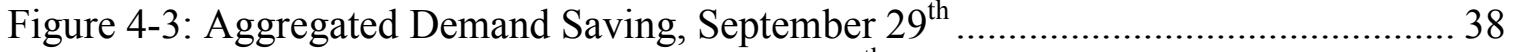

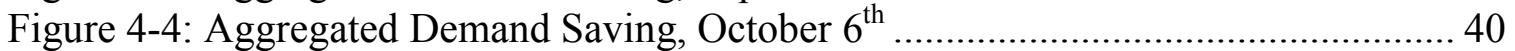

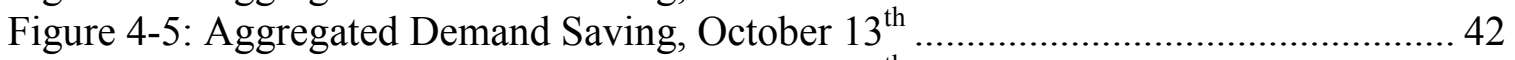

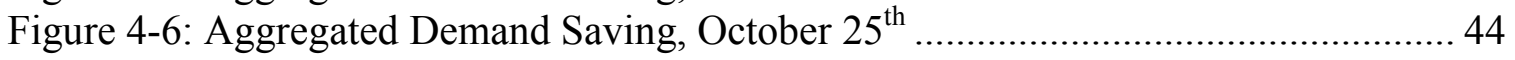

Figure 4-7: Chabot: Whole Building Power Demand of Pre-cooling Tests .................... 50

Figure 4-8: Chabot: Daily HVAC Energy Consumption of Pre-cooling Test Days......... 50 


\section{List of Tables}

Table E-1: Summary of Site Information .....................................................................vii

Table E-2: Baseline Peak and Maximum Demand Savings at Each Auto-CPP Site....... viii

Table 2-1: Steps for Site Recruitment...................................................................... 10

Table 2-2: Sites recruited for Auto-DR and Auto-CPP in 2003, 2004 and 2005 ............. 12

Table 2-3: Examples of Sites Pursued and Reasons Unable to Participate in Auto-CPP. 13

Table 2-4: Function of Relay Contacts (Internet relay and CLIR Box only) ................... 19

Table 2-5: Price Levels and Associated Behaviors.......................................................... 20

Table 3-1: Summary of Site Information................................................................... 25

Table 3-2: Summary of Site Auto-CPP Connectivity.................................................... 26

Table 3-3: Site-Specific Demand Response Strategies..................................................... 27

Table 3-4: Summary of Demand Response Strategies ………....................................... 29

Table 3-5: Desired EMCS trend points for demand response analysis ............................. 30

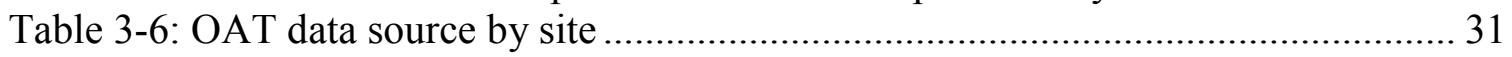

Table 4-1: Auto-CPP Preparation Status Spreadsheet ....................................................... 33

Table 4-2: Summary of Event Participation .................................................................... 34

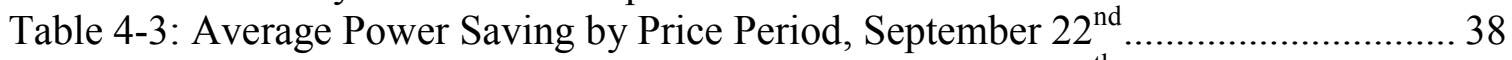

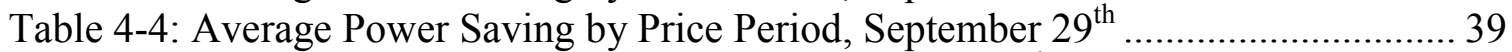

Table 4-5: Average Power Saving by Price Period, October $6^{\text {th }}$ …….............................. 41

Table 4-6: Average Power Saving by Price Period, October $13^{\text {th }}$ ……………………........ 43

Table 4-7: Average Power Saving by Price Period, October $25^{\text {th }}$.................................. 45

Table 4-8: Maximum Demand saving by Site and Non-Coincident Aggregated Saving. 47

Table 4-9: Hardware Cost of Each Connectivity Option for Auto-DR ............................ 47

Table 4-10: Summary of Cost for Auto-CPP Implementation .......................................... 48 


\section{Acknowledgements}

The authors are grateful for the extensive support from numerous individuals who assisted in this project:

- Ron Hofmann for his initial conceptualization and ongoing assistance with the automated demand response project.

- Laurie ten Hope, Mark Rawson and Dave Michel (California Energy Commission).

- Bob Kinert, Eric Linkugel, Sophia Mintun, and Peter Chan at PG\&E for program management and technical assistance effort.

- California Institute for Energy and the Environment for their assistance in the contract.

- Dan Hennage (Akuacom) for development of the DR Automation Server System

- Greg Wikler and Ammi Amarnath (EPRI Solutions) for collaborative research effort and the development of an EPRI report on the automated demand response research.

- Christine Shockman for her assistance in evaluating the decision-making perspectives of the participants.

- Ed Arens and Leah Zagreus at UC Berkeley for assistance in the comfort analysis.

- Al Hodgson, Toshifumi Hotchi, and William Fisk for the indoor environmental analysis task.

- Eric Linkugel (PG\&E), Scott Williams (Target), Rich Brown (LBNL) and Nance Matson (LBNL) for reviewing this report.

This project could not have been completed without the extensive assistance from building owners, facility engineers, project managers, and technology developers. The following organizations provided assistance in this project:

- Alameda County Water District: Greg Watson and Mark Lott

- Automatic Controls Engineering Corporation: Jose Espudo

- C\&C Building Automation: Mark Johnson and Thomas Hemby

- Chabot Space and Science Center: Dwight Fanning and Steven de Remedios

- Chevron Energy Solutions: Bruce Dickinson and Koichiro Kamoji

- Contra Costa County: Andrew Green and David Nyberg

- Echelon: Mike Tennefoss

- FAC Service: James Canoose and Lyle Woods

- Fremont Unified School District: Gene Wheatley, Rigo Perez and Carlos Carrillo

- Gilead Science: Eric Giles and Bob Nungester

- IKEA: Rick Betten and Prim Javier

- Jones Lang LaSalle (for Bank of America): William Young, Wilfred Freeman and Dave Ramsey

- Kenmark: Wayne Wiebe and Richard Hair 
- Lawrence Berkeley National Laboratory: William Iles, Howard Walter, Syed Ali and John Wunderlich

- Oracle Corporation: Mukesh Khattar and Chris Wilson

- Syserco: Erik Ahrens and Steve Alexander

- Target: Scott Williams, Tony Springman and Rita Outhabong

- United States Postal Service: Ray Levinson and Mel Abraham,

- Yamas Controls: Janey Kaster

- PG\&E Account Representatives: George Alfaro, Sonya Casares and Farnaz Firoozi, Kathy Lavezzo, Lorrie Lee, Aaron Rezendez Kim Ryle, Jason Shehan and Sharon Stout 


\section{Executive Summary}

\section{Background}

California utilities have been exploring the use of critical peak prices (CPP) to help reduce needle peaks in customer end-use loads. CPP is a form of price-responsive demand response (DR). Recent experience has shown that customers have limited knowledge of how to operate their facilities in order to reduce their electricity costs under CPP (Quantum 2004). While the lack of knowledge about how to develop and implement DR control strategies is a barrier to participation in DR programs like CPP, another barrier is the lack of automation of DR systems.

During 2003 and 2004, the PIER Demand Response Research Center (DRRC) conducted a series of tests of fully automated electric demand response (Auto-DR) at 18 facilities. Overall, the average of the site-specific average coincident demand reductions was $8 \%$ from a variety of building types and facilities. Many electricity customers have suggested that automation will help them institutionalize their electric demand savings and improve their overall response and DR repeatability. This report focuses on and discusses the specific results of the Automated Critical Peak Pricing (Auto-CPP, a specific type of Auto-DR) tests that took place during 2005, which build on the automated demand response (Auto-DR) research conducted through PIER and the DRRC in 2003 and 2004.

\section{Goals and Objectives}

The long-term goal of this project is to understand the technical opportunities of automating demand response and to remove technical and market impediments to largescale implementation of automated demand response (Auto-DR) in buildings and industry. A second goal of this research is to understand and identify best practices for DR strategies and opportunities. The specific objectives of the Automated Critical Peak Pricing test were as follows:

- Demonstrate how an automated notification system for critical peak pricing can be used in large commercial facilities for demand response (DR).

- Evaluate effectiveness of such a system.

- Determine how customers will respond to this form of automation for CPP.

- Evaluate what type of DR shifting and shedding strategies can be automated.

- Explore how automation of control strategies can increase participation rates and DR saving levels with CPP.

- Identify optimal demand response control strategies.

- Determine occupant and tenant response.

\section{Approach}

The basic design of the project was to recruit ten to twenty facilities to participate in fully automated critical peak pricing. Lawrence Berkeley National Laboratory collaborated 
with the Pacific Gas and Electric Company (PG\&E) to trigger price signals using PG\&E's Interact II system. A Demand Response Automation Server was configured to work with Interact to initiate Internet communications with an Internet-based communications system developed by LBNL and Akuacom known as the Demand Response Automation Server. The DR Automation Server communicated with individual buildings over the Internet to provide signals that communicate the variable electricity prices. Qualified sites were configured to respond to price signals transmitted over the Internet using Internet gateway or relay systems. Pre-selected electric loads automatically responded to the Internet signals using fully automated DR control strategies. No new energy management control system (EMCS) hardware or controls software were within the buildings for the end-use controls. All but one of the sites initiated controls directly through the EMCS.

The recruitment process to bring facilities into the program began in May 2005, which was late to include a large number of buildings in the tests for the 2005 CPP time period. One key lesson regarding the process used for the project is that we could have had greater levels of participation if the recruitment process started earlier in the year.

The objective of the recruitment process was to identify a broad range of sites to represent numerous market segments and customer classes. Representatives of each site were interviewed to determine what their potential DR strategies would be. An extensive evaluation of the demand saving data was performed using hourly electric load shapes to develop a weather normalized baseline and the CPP baseline. Interviews were conducted to determine the cost for configuring the building for fully automated CPP. A survey of the facilities management staff was conducted following each event.

The project also included three sub-studies to examine thermal comfort at three sites, precooling at two sites, and indoor air quality with reductions in ventilation at a retail building.

\section{Results}

This project successfully demonstrated that automated DR is technically feasible with existing technology and buildings can provide significant levels of automated demand response within existing CPP programs. Table E-1 lists the fifteen buildings that participated in the study - representing approximately two million $\mathrm{ft}^{2}$ of commercial space. The buildings include office buildings, schools, retail chains, a museum, a laboratory, two data centers and a postal facility. While the project demonstrated success for many of the sites, there were a number of technical challenges at several of the test sites. There were significant delays within PG\&E to configure the sites for CPP independent of the automation activities from LBNL. A few of the sites were not properly configured to participate in the fully automated CPP tests, but are included in the report because of the effort spent bringing them into the program as well as the lessons learned regarding that effort. Two of the sites participated in the Auto-CPP response and the DR analysis, but were never fully on the CPP tariff.

Figure E-1 shows the aggregated electric load shape of eight sites that participated in the fully automated CPP event that occurred on September $29^{\text {th }}, 2005$. A previous Auto-CPP event, in early August, had only two sites participating because the Auto-CPP systems 
were not ready for the event. For the eight sites that participated in the fully automated CPP event on September $29^{\text {th }}$, the average demand response ranged from 0 to $24 \%$ per site for the medium price period and 4 to $28 \%$ per site during the high price period, with an average of $9 \%$ and $14 \%$ overall for the two price periods. The total aggregated demand savings reached $263 \mathrm{~kW}$ during the medium price period and $590 \mathrm{~kW}$ during the high price period accounting for $3 \%$ and $8 \%$ of the total peak load of $7.7 \mathrm{MW}$.

Table E-1: Summary of Site Information

\begin{tabular}{|c|c|c|c|c|c|c|c|c|}
\hline \multirow{2}{*}{ Site Name } & \multirow{2}{*}{ Short Name } & \multirow{2}{*}{ Location } & \multirow{2}{*}{\begin{tabular}{|l|} 
CPP \\
Zone \\
\end{tabular}} & \multirow{2}{*}{ Building Use } & \multirow{2}{*}{\begin{tabular}{c|} 
\# of \\
Bldg
\end{tabular}} & \multicolumn{2}{|c|}{ Floor Space } & \multirow{2}{*}{\begin{tabular}{|c|} 
Peak \\
Load kW \\
\end{tabular}} \\
\hline & & & & & & Total & Conditioned & \\
\hline $\begin{array}{l}\text { Alameda County Water } \\
\text { District, Headquarter }\end{array}$ & ACWD & Fremont & 2 & Office, lab & 1 & 51,200 & 51,200 & 347 \\
\hline $\begin{array}{l}\text { Bank of America, } \\
\text { Concord Technology } \\
\text { Center } \\
\end{array}$ & B of $A$ & Concord & 2 & $\begin{array}{l}\text { Office, data } \\
\text { center }\end{array}$ & 4 & 616,000 & 708,000 & 5680 \\
\hline $\begin{array}{l}\text { Chabot Space and } \\
\text { Science Center, Building } \\
1 \& 2\end{array}$ & Chabot & Oakland & 2 & Museum & 2 & 86,000 & 86,000 & 333 \\
\hline $\begin{array}{l}\text { Contra Costa County, } \\
2530 \text { Arnold }\end{array}$ & 2530 Arnold & Martinez & 2 & Office & 1 & 131,000 & 131,000 & 528 \\
\hline $\begin{array}{l}\text { Contra Costa County, } 50 \\
\text { Douglas }\end{array}$ & 50 Douglas & Martinez & 2 & Office & 1 & 90,000 & 90,000 & 422 \\
\hline $\begin{array}{l}\text { Echelon, San Jose } \\
\text { Headquarter }\end{array}$ & Echelon & San Jose & 2 & $\begin{array}{l}\text { Corporate } \\
\text { Headquarter }\end{array}$ & 1 & 75,000 & 75,000 & 403 \\
\hline $\begin{array}{l}\text { Fremont Unified School } \\
\text { District, Irvington High } \\
\text { School }\end{array}$ & Irvington & Fremont & 2 & Highschool & 1 & 186,000 & 186,000 & $\mathrm{~N} / \mathrm{A}$ \\
\hline $\begin{array}{l}\text { Gilead Science, } 300 \\
\text { Lakeside Dr. }\end{array}$ & Gilead 300 & Foster City & 1 & Office & 1 & 83,000 & 83,000 & N/A \\
\hline $\begin{array}{l}\text { Gilead Science, } 342 \\
\text { Lakeside Dr. } \\
\end{array}$ & Gilead 342 & Foster City & 1 & Office, Lab & 1 & 32,000 & 32,000 & 464 \\
\hline $\begin{array}{l}\text { Gilead Science, } 357 \\
\text { Lakeside Dr. } \\
\end{array}$ & Gilead 357 & Foster City & 1 & Office, Lab & 1 & 33,000 & 33,000 & 664 \\
\hline $\begin{array}{l}\text { IKEA, East Palo Alto } \\
\text { Store }\end{array}$ & IKEA & $\begin{array}{l}\text { East Palo } \\
\text { Alto }\end{array}$ & 1 & Retail & 1 & 300,000 & 300,000 & 2238 \\
\hline $\begin{array}{l}\text { Lawrence Berkeley } \\
\text { National Laboratory, } \\
\text { Oakland Scientific } \\
\text { Facility } \\
\end{array}$ & LBNL OSF & Oakland & 2 & $\begin{array}{l}\text { Data center, } \\
\text { Office }\end{array}$ & 1 & 90,000 & 70,000 & 2189 \\
\hline $\begin{array}{l}\text { Oracle Corporation, } \\
\text { Rocklin }\end{array}$ & Oracle & Rocklin & 2 & Office & 2 & 100,000 & 100,000 & 808 \\
\hline Target, Hayward Store & Target & Hayward & 2 & Retail & 1 & 130,000 & 130,000 & 428 \\
\hline \begin{tabular}{|l|} 
United States Postal \\
Service, San Jose \\
Process and Distribution \\
Center \\
\end{tabular} & USPS & San Jose & 2 & Postal service & 1 & 390,000 & 390,000 & 1676 \\
\hline Total & & & & & 19 & $2,393,200$ & $2,465,200$ & 16,179 \\
\hline
\end{tabular}

CPP Zone 1 includes San Francisco and the Peninsula. CPP Zone 2 includes the rest of the PG\&E service territory.

Table E-2 shows the baseline peak demand, the maximum 15-minute demand savings for each Auto-CPP test and the non-coincident maximum demand savings. If all twelve sites reached their maximum saving simultaneously, a total of approximately $2 \mathrm{MW}$ of demand response is available from these twelve sites that represent about two million $\mathrm{ft}^{2}$. 
Using the summation of the average demand savings for each of the twelve sites results in an average demand saving of approximately $1 \mathrm{MW}$. These results indicate that 1 to 2 MW of demand saving achievement can be expected for two million $\mathrm{ft}^{2}$ of buildings ( 0.5 to $1.0 \mathrm{~W} / \mathrm{ft}^{2}$ of demand saving).

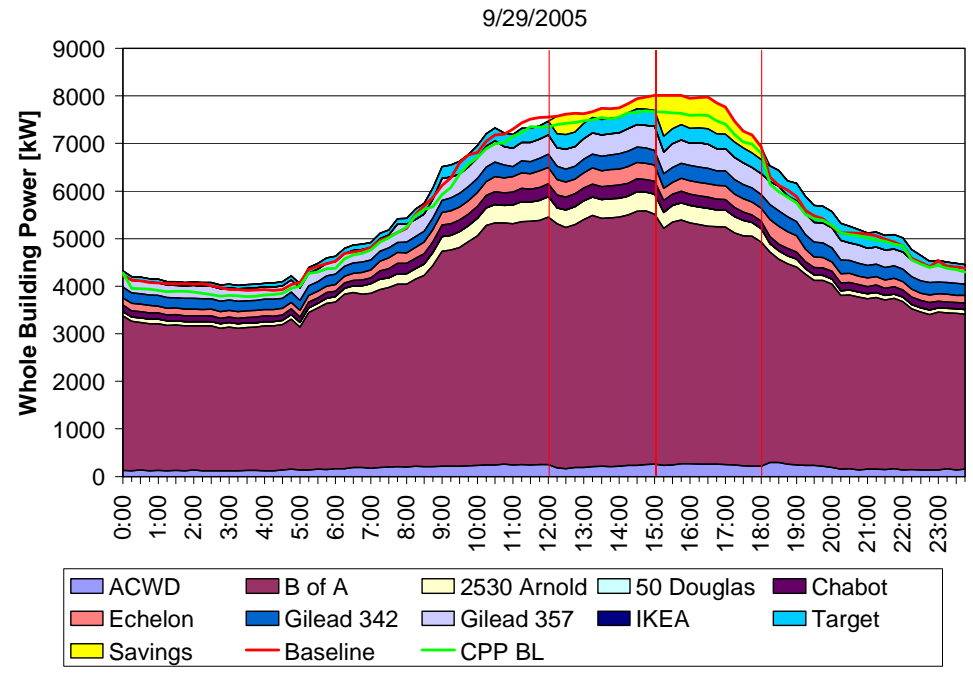

Figure E-1: Automated CPP Aggregated Demand Saving Results, September 29

Table E-2: Baseline Peak and Maximum Demand Savings at Each Auto-CPP Site

\begin{tabular}{|c|c|c|c|c|c|c|c|c|c|c|}
\hline & & \begin{tabular}{|l|} 
Aug-08 \\
\end{tabular} & Sep-22 & Sep-29 & Oct-06 & Oct-13 & Oct-25 & Nov-10 & 2004 & Max \\
\hline \multirow[t]{2}{*}{ ACWD } & Baseline Peak kW & & & 330 & 253 & 290 & 238 & & & 3330 \\
\hline & Max Savings kW & & & 101 & 74 & 83 & 77 & & & 101 \\
\hline \multirow[t]{2}{*}{ B of $A$} & Baseline Peak kW & & & 5311 & & 5163 & 5053 & & & 5053 \\
\hline & Max Savings kW & & & 291 & & 219 & 552 & & & 552 \\
\hline \multirow[t]{2}{*}{ Chabot } & Baseline Peak kW & & 225 & 308 & 244 & 270 & & & & 308 \\
\hline & Max Savings kW & & 19 & 88 & 36 & 42 & & & & 88 \\
\hline \multirow[t]{2}{*}{2530 Arnold } & Baseline Peak kW & 505 & 419 & 431 & 404 & 406 & 345 & & & 505 \\
\hline & Max Savings kW & 176 & 119 & 90 & 63 & 89 & 40 & & & 176 \\
\hline \multirow[t]{2}{*}{50 Douglas } & Baseline Peak kW & 381 & & & & & 259 & & & 381 \\
\hline & Max Savings kW & 95 & & & & & 78 & & & 95 \\
\hline \multirow[t]{2}{*}{ Echelon } & Baseline Peak kW & & 334 & 403 & 363 & 359 & 304 & & & 403 \\
\hline & Max Savings kW & & 115 & 143 & 132 & 117 & 84 & & & 143 \\
\hline \multirow[t]{2}{*}{ Gilead 342} & Baseline Peak kW & & 288 & 384 & 289 & 340 & 278 & & & 288 \\
\hline & Max Savings kW & & 94 & 75 & 45 & 55 & 80 & & & 94 \\
\hline \multirow[t]{2}{*}{ Gilead 357} & Baseline Peak kW & & & 607 & & 455 & 443 & & & 607 \\
\hline & Max Savings kW & & & 150 & & 119 & 145 & & & 150 \\
\hline \multirow[t]{2}{*}{ IKEA } & Baseline Peak kW & & & & & 1982 & 1803 & & & 1982 \\
\hline & Max Savings kW & & & & & 321 & 223 & & & 321 \\
\hline \multirow[t]{2}{*}{ Oracle } & Baseline Peak kW & & & & & & & 507 & & 507 \\
\hline & Max Savings kW & & & & & & & 65 & & 65 \\
\hline \multirow[t]{2}{*}{ Target } & Baseline Peak kW & & 314 & 364 & 328 & 341 & 296 & & & 341 \\
\hline & Max Savings kW & & 52 & 53 & 60 & 64 & 49 & & & 64 \\
\hline USPS* & $\begin{array}{l}\text { Baseline Peak kW } \\
\text { Max Savings kW }\end{array}$ & & & & & & & & $\begin{array}{r}1483 \\
333 \\
\end{array}$ & $\begin{array}{r}1483 \\
333\end{array}$ \\
\hline \multirow[t]{2}{*}{ Total } & Baseline Peak kW & 886 & 1579 & 8138 & 1881 & 9608 & 9020 & 507 & 1483 & 12189 \\
\hline & Max Savings kW & 272 & 399 & 992 & 410 & 1108 & 1329 & 65 & 333 & 2182 \\
\hline
\end{tabular}

* 2004 data (Oct-13) is used for USPS because USPS failed to conduct demand response in 2005. 


\section{Introduction}

\subsection{Background}

California utilities have been exploring the use of critical peak prices (CPP) to help reduce needle peaks in customer end-use loads. CPP is a form of price-responsive demand response. Recent experience has shown that customers have limited knowledge of how to operate their facilities in order to reduce their electricity costs under CPP (Quantum 2004). While the lack of knowledge about how to develop and implement DR control strategies is a barrier to participation in DR programs like CPP, another barrier is the lack of automation of DR systems. Most DR activities are manual and require building operations staff to first receive emails, phone calls, and pager signals; and second, to act on these signals to execute DR strategies. The various levels of DR automation can be defined as follows. Manual Demand Response involves a laborintensive approach such as manually turning off or changing comfort set points at each equipment switch or controller. Semi-Automated Demand Response involves a preprogrammed demand response strategy initiated by a person via centralized control system. Fully-Automated Demand Response does not involve human intervention, but is initiated at a home, building, or facility through receipt of an external communications signal. The receipt of the external signal initiates pre-programmed demand response strategies. We refer to this as Auto-DR. One important concept in Auto-DR is that a homeowner or facility manager should be able to "opt out" or "override" a DR event if the event comes at time when the reduction in end-use services is not desirable. AutoCPP is a specific type of Auto-DR and uses the Critical Peak Pricing program price signals to initiate the DR strategies.

From the customer side, modifications to the site's electric load shape can be achieved by modifying end-use loads. Examples of demand response strategies include reducing electric loads such as dimming or turning off non-critical lights, changing comfort thermostat set points, or turning off non-critical equipment. These demand response activities are triggered by specific actions set by the electricity service provider, such as dynamic pricing or demand bidding. Many electricity customers have suggested that automation will help them institutionalize their demand response. The alternative is manual demand response -- where building staff receive a signal and set in motion a set of activities to reduce demand. The LBNL research has found that many building EMCS and related lighting and other controls can be pre-programmed to initial and manage electric demand response.

This report focuses on and discusses the specific results of the Automated Critical Peak Pricing (Auto-CPP, a specific type of Auto-DR) tests that took place during 2005, which build on the automated demand response (Auto-DR) research conducted through PIER and the DRRC in 2003 and 2004. For continuity, the 2003 and 2004 projects are briefly discussed. More information on these tests can be found in their project reports (LBNL 2004 and LBNL 2005). 


\section{Auto-DR Project}

During 2003 and 2004, the PIER Demand Response Research Center (DRRC) conducted a series of tests of fully automated electric demand response (Auto-DR) at 18 facilities. Overall, the average of the site-specific average demand reductions was $8 \%$ from a variety of building types and facilities.

The first Auto-DR research and field tests were conducted in summer 2003, funded by CEC PIER (LBNL 2004). These tests resulted in an average demand savings of $382 \mathrm{~kW}$ for five sites. The maximum co-incident demand savings was $519 \mathrm{~kW}(11 \%$ maximum demand savings). The average of the site-specific demand savings was $8 \%$ demand savings over the demand response period. The best performing building achieving $28 \%$ demand savings over the demand response period. The tests were designed to develop and evaluate the feasibility and nature of Auto-DR strategies in large facilities. The research included the development of new communication systems, site recruitment, characterization of existing control and communications systems, and evaluation of the Auto-DR field tests. This study also examined the building owners and managers' decision-making processes. This project sought to develop and test a real-time signal for automated demand response that provided a common communication infrastructure for diverse facilities. The six facilities recruited for this project were selected from the set of facilities that received CEC funds for new DR technology during California's 2000-2001 electricity crises (AB970, 2000 and SB-5X, 2001).

A significant goal of this research was to perform a two-week test of fully automated DR test at four to six facilities. We worked with each facility's staff to develop a demand response strategy that would result in a larger electric demand savings at higher electricity prices. The test consisted of providing a single fictitious continuous electric price signal to each facility. The technology used for the communications is known as Extensible Markup Language (XML) with "Web services". Control and communications systems at each site were programmed to check the latest electricity price published by the DR Automation Server and automatically act upon that signal. All of the facilities had Energy Information Systems (EIS) and Energy Management and Control Systems (EMCS) that were programmed to automatically begin demand response control when the price rose from $\$ 0.10 / \mathrm{kWh}$ to $\$ 0.30 / \mathrm{kWh}$. The second level price signal increased to $\$ 0.75 / \mathrm{kWh}$. Five sites successfully participated in the test.

The 2003 study demonstrated a number of key issues that relate to Automated DR, and DR in general:

- Fully automated DR is technically feasible with minor enhancements to current state-of-the-art technology - The facilities that participated in the study used their existing EIS systems for the Auto-DR test. In three cases, an electronic interface component was added to provide communications functions necessary for Auto-DR. No additional hardware was required at the other two sites. All five sites required custom software programming to enable Auto-DR functionality. The time required for programming at each site varied from a couple of days to about one month of labor. The technology used offers a glimpse of the issues that may need to be addressed with a large-scale deployment effort. 
- New Internet technology enhances the capabilities of existing building systems to enable demand response - Although each of the participating facilities had different types of EMCS and EIS systems, they were "unified" in the sense that they all monitored and responded to a price signal from the one common DR Automation Server. The custom software at each site was programmed using the emerging technology standards "XML" and "Web services". An examination of the use of $\mathrm{XML} / \mathrm{Web}$ services and the associated interfaces to existing EMCS and EIS systems showed that new internet technology enhances the capabilities.

- Automation is likely to enhance demand response programs - The electric consumers we worked with indicated that automation of DR is likely to foster greater participation in various DR markets by decreasing the time needed to prepare for a DR event. Automation may likely increase the number of times a facility may be willing to save loads, and perhaps improve the depth of the savings, and the number of facilities involved in DR.

- Large facilities support the objectives of DR - This project involved extensive discussions and interactions with five large organizations and institutions. Excellent support and assistance in this research was obtained. The energy managers at these organizations believe that DR programs and tariffs will increase in their importance and prominence, and new technology will assist them in participating in these programs.

- New knowledge is needed to procure and operate technology and strategies for DR - DR is a complex concept. Facility operators need to understand DR economics, controls, communications, energy measurement techniques, and the relation between changes in operation and electric demand. Such understanding may involve numerous people at large facilities. Current levels of outsourcing of control services complicate the understanding of control strategies and system capabilities.

\section{Auto-DR Project}

The 2004 LBNL Auto-DR tests resulted in an average demand savings of about $14 \%$ at fifteen sites (LBNL 2005). The 2004 Auto-DR tests had four specific objectives. One objective was to explore new control and communication systems, including gateway and relay technologies. Another objective was to evaluate the size of the demand saving potential of the 2003 Phase 1 buildings in warmer weather test events. These buildings participated in a warm weather 2004 "Retest". A third objective was to evaluate how the test could be scaled up to allow more buildings to participate. A fourth objective was to better understand the range of demand response control strategies used in large facilities. These last two objectives were evaluated in a "Scaled Up" test. All of the 2004 tests were three-hour DR events. The facility managers were unaware of the impending DR events.

The communication systems for the 2004 tests differed from the 2003 tests in that new methods of communication were used. During the 2003 tests, all of the sites had some kind of Web-based Energy Information System (EIS) and PC-based Energy Management and Control System (EMCS). During the 2004 tests, five of the 18 sites used an Internet 
relay that connected directly to the EMCS control panel. This new method allowed buildings with conventional control systems to participate in the test.

This research demonstrated that fully automated demand response systems are technically feasible for buildings with a wide range of control systems - from conventional EMCS to highly sophisticated EMCS with telemetry communication. LBNL demonstrated the features of Automated DR with EMCS and XML (eXtensible Markup Language). Both Internet gateways and Internet relays were tested. There are important pros and cons to these two systems. The Internet gateways are more sophisticated, having a greater set of functions. They are, however, more expensive as well.

\subsection{Goals and Objectives of Automated CPP}

As mentioned above, a long-term goal of this multi-year research project is to understand the technical opportunities of automating demand response and to remove technical and market impediments to large-scale implementation of Auto-DR in buildings and industry. A second goal of this research is to understand and identify best practices for DR strategies and opportunities. The results of this research are intended to be of direct value to the Pacific Gas and Electric Company and other California utilities in their effort to achieve DR and CPP participation targets. The research results are also intended to be of interest to a broader DR audience, including utilities, end-use customers (building engineers, owners, and operators), policy makers (California Energy Commission and CPUC), and related stakeholder groups. Specific objectives of this project are:

- Demonstrate how an automated notification system for critical peak pricing can be used in large commercial facilities for demand response (DR). Evaluate the effectiveness of such a system. Determine how customers will respond to this form of automation for CPP.

- Evaluate what types of DR shifting and shedding strategies can be automated.

- Explore how automation of control strategies can increase participation rates and demand saving levels with CPP.

- Identify optimal DR control strategies in large facilities

- Determine occupant and tenant response

This project involved collaboration between the PIER Demand Response Research Center and the Pacific Gas and Electric Company. The DRRC developed the DR Automation Server technology that was customized for the demonstration project. PG\&E funded the tasks that dealt with the site recruitment and collaboration with the PG\&E Customer Service Representatives. The remainder of this report is organized as follows.

- Section 2 - Experimental Design and Procedures - discusses the project design and the Automated DR systems.

- Section 3 - Auto-CPP Site Characteristics - discusses the facilities that participated in the study. 
- Section 4 - Project Results - provides the project results for the Auto-CPP test events. This section also discusses the results from the sub-analyses related to comfort, indoor environmental conditions, and pre-cooling research.

- Section 5 - Discussion - examines outstanding issues with the project.

- Section 6 - Summary and Future Research - considers key findings and future research plans beyond 2005.

- $\quad$ Section 7 - References

- Appendices

○ Appendix A - Outreach Documents - lists the documents used to recruit the participants.

- Appendix B - Site Descriptions \& Demand Saving Details - contains detailed descriptions of each Auto-CPP sites along with extensive data tables on the Auto-CPP results.

○ Appendix C - Post Test Interview Notes - reviews results from interviews following each test day.

○ Appendix D - Acronyms and Terminology 


\section{Experimental Design and Procedure}

\subsection{Project Overview}

LBNL and PG\&E collaborated to recruit ten to twenty facilities to participate in the fully automated critical peak pricing tests (Auto-CPP). During the CPP time period, PG\&E would trigger price signals that would propagate to each facility via the established PG\&E CPP notification system to provide variable pricing for electricity. Qualified sites were to be configured to respond to automated price signals transmitted over the Internet (LBNL DR Automation Server). During the 2005 summer test period, as the electricity price increased during a CPP event, pre-selected electric loads would be automatically curtailed based on each facility's pre-programmed control strategy. In order to participate in the LBNL/PG\&E Auto-CPP test program, each site had to meet the following requirements:

- Participate in PG\&E's voluntary Critical Peak Pricing program.

- Use an energy management control system (EMCS) or energy information system (EIS).

- Have interval meter connected to PG\&E's InterAct $\mathrm{II}^{\mathrm{TM}}{ }^{1}$

- Provide access to the Internet (be able to surf the Web from offices at the site). Having a Web-enabled EMCS or EIS was preferred but not required.

- Select DR control strategies. Global zone temperature set point setup/setback, lighting reductions, or shutting off other non-critical loads are examples of such strategies. Each site's facilities staff was to consider these and other strategies that were best suited to their facility.

- Program or hardwire energy management control systems to curtail loads based on relay contact or XML signal. Simple program changes were to be conducted by staff or contractor.

PG\&E's critical peak pricing (CPP) program is a voluntary alternative to traditional timeof-use rates. Schedule E-CPP is available to PG\&E bundled-service customers with billed maximum demands of $200 \mathrm{~kW}$ or greater, and served on PG\&E Demand Time-Of-Use (TOU) electric rates. The CPP program operates during the summer months (May $1^{\text {st }}$ through October $31^{\text {st }}$ ). In order to be on this tariff, customers need to have an interval meter that can be read by PG\&E remotely and Internet access to PG\&E's Inter-Act II. Also, customers need to have the required metering and notification equipment in place prior to participation in the CPP program. The additional energy charges for customers on this tariff on CPP operating days are as follows (PG\&E 2005):

CPP Moderate-Price Period Usage: The total effective energy charge for usage during the CPP Moderate-Price Period will be three (3) times the customer's summer part-peak

\footnotetext{
${ }^{1}$ Energy Information System (EIS) provided by PG\&E and powered by Itron to archive/visualize 15minute electric interval meter data for each account. PG\&E customers who have over $200 \mathrm{~kW}$ can access the data via a web browser.
} 
energy rate under their otherwise-applicable rate schedule multiplied by the actual energy usage. The CPP Moderate-Price period is from 12:00 Noon to 3:00 PM on the CPP operating days.

CPP High-Price Period Usage: The total effective energy charge for usage during the CPP High-Price Period will be five (5) times the customer's summer on-peak energy rate under their otherwise-applicable rate schedule multiplied by the actual energy usage. The CPP High-Price period is from 3:00 PM to 6:00 PM on the CPP operating days. This tariff is illustrated in Figure 2-1.

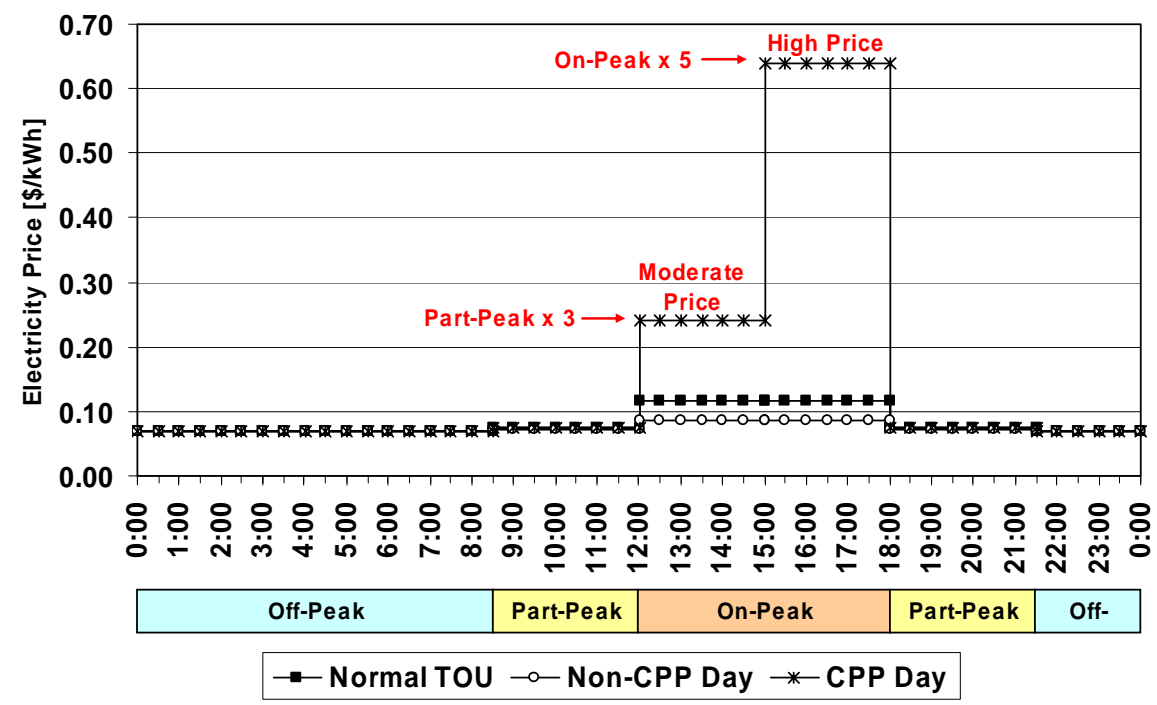

Figure 2-1: PG\&E Critical Peak Pricing Tariff Structure

Customers taking service under Schedule E-CPP pay reduced total effective TOU energy rates through offsetting summer on-peak and part-peak rate credits for usage on those days that are not declared as CPP operating days. Schedule E-CPP charges and credits will only be applicable during the summer season (May $1^{\text {st }}$ to October $31^{\text {st }}$ ).

As mentioned above, in order to receive notification of the CPP event, customers need to have access to the Internet and an e-mail address. In addition, all customers need to have an alphanumeric pager that is capable of receiving a text message sent via the Internet. PG\&E will notify customers by 3:00 PM on a day-ahead basis when a CPP operation day will occur the next business day. A CPP event will only be called Monday through Friday, excluding holidays.

CPP operating days will ordinarily be determined based on day-ahead maximum temperature forecasts at specific locations within each of two designated PG\&E zones. The two zones are Zone 1 (San Francisco and Peninsula) and Zone 2 (all other areas to which PG\&E provides service).

Beginning May $1^{\text {st }}$ of the 2005 summer season, the initial forecasted temperature thresholds for triggering CPP events were:

- Zone 1: $92^{\circ} \mathrm{F}$ (average of forecasts for San Francisco and San Jose) 
- Zone 2: $96^{\circ} \mathrm{F}$ (average of forecasts for San Jose, Concord, Redding, Sacramento and Fresno)

PG\&E could adjust the forecasted temperature thresholds up or down over the course of the summer as necessary to achieve the CPP program design basis of 12 operating days each summer.

\section{Site Recruitment}

The site recruitment process started in May 2005. The original site-recruitment objective was to identify a broad range of sites to represent numerous market segments. PG\&E provided a list of CPP participants along with their peak demand saving data. The list included about 225 sites. We selected 54 sites based on two criteria: sites where the previous savings exceeded $10 \%$ of their peak load and diversity in the market segments.

In addition, LBNL met with and discussed the project with several major control companies. The objectives of these meetings were to: determine their interest in collaborating on this project, identify any sites they might nominate for the test, and obtain their feedback on the project's technical approach.

\section{Recruitment of CPP Customers}

After the selection of 54 potential candidates from the CPP participant list, PG\&E suggested that we directly coordinate our efforts with the account representatives so that they could provide contact information to LBNL for each account. As the PG\&E account representative contact information became available from the program manager, LBNL contacted the account representatives, informed them about the program and e-mailed the flyer describing the field tests. LBNL also inquired whether the candidate site had an energy management and control system (EMCS) system as the majority of previous Auto-DR sites have used their EMCS as a major component of their demand response strategy. If the potential site had an EMCS, LBNL asked the account representative if they thought the site would be interested in participating in the test. If the response was positive, LBNL asked them to either introduce the researcher and Auto-CPP test to their clients via e-mail or to schedule a meeting where the researcher could present an overview of the test. In addition, each representative contacted was asked to nominate sites that they believe might be interested in participating.

Responses from the account representatives varied throughout this process. Examples of issues confronted in the project as follows:

- Account representative did not respond to LBNL's e-mails. The PG\&E project managers had to contact them and ask them to respond.

- Account representative reported that the selected site did not have an EMCS.

- Account representative reported that the site had an unsophisticated EMCS and used manual demand response for CPP events.

- Account representative reported that the site would not be a good candidate due to constraints on facility management time and budget constraints or retrofit underway at the site. 
- Account representative suggested additional sites that might be more interested and responsive to the test.

LBNL also met with Quantum Consulting to request information on the CPP customers who participated in their sub-metering study. Quantum performed the evaluation of the 2004 CPP programs in May 2004 (Quantum 2004). Out of the five participants in their study, all were included in the short list derived from the CPP participant list provided by PG\&E. Some of these sites did not have an EMCS or they conducted manual demand response.

LBNL contacted all of the 54 pre-selected PG\&E CPP sites by e-mail and followed up with phone calls. Sites that were most receptive were those planning or implementing some sort of a building controls work in their facility.

\section{Assistance from Building Automation and Controls Companies}

LBNL had direct conversations with Siemens, Honeywell, Syserco, Yamas and C\&C Building Automation. LBNL met with Siemens and Honeywell to discuss the site selection criteria and the details of the CPP tariff. Honeywell did not nominate any buildings but provided information on similar research in New York that was conducted by EPRI about ten years ago. Although an additional telephone conference was held with the Siemens' local office in the Bay Area, Siemens was also unable to nominate any buildings for this study. The CPP participation requirement for the buildings was challenging because the economics of the demand saving potential was not well understood. Some facility managers were concerned that the energy costs could increase under CPP. Although PG\&E offered bill protection to the participants for their first year and any possible negative financial impact on the monthly bills during the CPP period could be resolved later, bill impacts were still an issue for the decision makers. Syserco, Yamas and C\&C Controls were contacted by phone to explain the CPP tariff, the test and the site selection criteria. While Syserco had similar concerns with Siemens and Honeywell, Yamas and C\&C immediately nominated Chabot Space and Science Center respectively. One possible cause of the difference in outreach results among these four control companies is LBNL worked with local Bay Area Yamas and C\&C offices, while the contact with Siemens and Honeywell were with national offices.

\section{Outreach at Meetings and Conferences}

In addition to the outreach activities through the PG\&E customers account managers and outreach to control companies, the project team presented plans and concepts for the research at numerous conferences and meetings. These meetings included:

- The Silicon Valley Leadership Group Energy Forum

- National Conference on Building Commissioning

- American Council for Energy Efficient Economy Summer Study on Energy Efficiency in Buildings

- PG\&E’s Program Advisory Group (PAG) Cross Cutting Meeting

- PG\&E Integrated Demand Side Management Meeting 
- Echelon Partners Controls Meeting

- Peak Load Management Alliance

- California Energy Commission Meetings (to add specific ones)

\section{Recruitment Procedures}

The individual steps for site recruitment are summarized in Table 2-1. Anytime a candidate is introduced to the program, LBNL researchers followed the outlined steps below to guarantee their participation:

Table 2-1: Steps for Site Recruitment

\section{Step 1. Does the site have an EMCS?}

If no, stop.

If yes go to Step 2.

Step 2. Are they CPP customers?

If no, go to Step 3.

If yes, make a note of who their account representative is. Note their PG\&E account ID. Also, note type/vendor and capability of EMCS. Go to Step 4.

Step 3. Would they like to join CPP so that they can be in the AUTO-CPP pilot?

If no, stop.

If yes, find out who the account rep is from PGE. Questions to ask:

1. Do they already have interval meters and an Interact account?

2. What is the type/vendor and capability of their EMCS?

3. Follow through their signing process.

Once they sign up for CPP, go to Step 4;

Step 4. Take the following action towards completion of Auto-CPP system setup.

1. Sign the MOU and return it to LBNL.

2. Fill out the checklist and return it to LBNL.

3. Document demand response strategy.

4. Establish data points for trending.

5. Decide on a connectivity option.

6. Provide the IP relay/gateway.

7. Provide a verbal overview of the process if needed.

8. Test the connection.

Table 2-2 lists the fifteen sites recruited for the Auto-CPP test, along with the other twelve sites that participated in 2003 and 2004 tests. Notice that only one site, Bank of America, participated in all three tests ${ }^{2}$. Five of the sites that participated in the 2004

\footnotetext{
${ }^{2}$ This site was the subject of a case studies reported in the appendices of the 2004 Auto-DR tests. The facility demand saving is larger in 2005 than in the previous two years after significant controls and system analysis. The site has pneumatic zone controls that limit closed loop control opportunities.
} 
Auto-DR tests also participated in the 2005 Auto-CPP tests. Three sites (Fremont Unified School District, two buildings of Gilead Science) had been enrolled in CPP prior to Summer 2005. Most of the other sites were enrolled during summer 2005 - after the CPP program period started on May $1^{\text {st }}$. One of the Gilead Science buildings (300 Lakeside Dr.) signed up for CPP, but CPP was not activated due to delays in installing the interval meter. IKEA also signed up for CPP, but CPP was not activated because they couldn't complete the communications test ${ }^{3}$. LBNL OSF ended up not signing up on CPP because it took too much effort to get permission to switch the facility's utility rate.

\footnotetext{
${ }^{3}$ PG\&E requires all CPP participants to conduct a communication test which confirms the participant receive both notification e-mail and e-page. IKEA doesn't provide business pagers nor allow employees to use their personal pagers. Therefore, IKEA couldn't receive an e-page, and couldn't activate CPP.
} 
Table 2-2: Sites recruited for Auto-DR and Auto-CPP in 2003, 2004 and 2005

\begin{tabular}{|c|c|c|c|c|c|c|}
\hline Site & Auto-DR Sites & $\begin{array}{c}\text { Auto-DR } \\
2003\end{array}$ & $\begin{array}{c}\text { Auto-DR } \\
2004\end{array}$ & $\begin{array}{c}\text { Auto-CPP } \\
2005\end{array}$ & $\begin{array}{c}\text { CPP } \\
\text { Program }\end{array}$ & Contact Method \\
\hline 1 & $\begin{array}{l}\text { Alameda County } \\
\text { Water District }\end{array}$ & - & - & Yes & $\begin{array}{l}\text { Summer } \\
2005\end{array}$ & $\begin{array}{l}\text { Recruited by LBNL and PG\&E Account } \\
\text { Representative }\end{array}$ \\
\hline 2 & Bank of America & Yes & Yes & Yes & $\begin{array}{l}\text { Summer } \\
2005\end{array}$ & AB970 \\
\hline 3 & $\begin{array}{l}\text { Chabot Space \& } \\
\text { Science Center }\end{array}$ & - & - & Yes & $\begin{array}{l}\text { Summer } \\
2005\end{array}$ & $\begin{array}{l}\text { Collaboration with LBNL on Oakland } \\
\text { Energy Partners Retrocommissioning. }\end{array}$ \\
\hline 4 & $\begin{array}{l}\text { Contra Costa County: } \\
2530 \text { Arnold }\end{array}$ & - & Yes & Yes & $\begin{array}{c}\text { Summer } \\
2005\end{array}$ & $\begin{array}{l}\text { DOD Western Grid Energy Study } \\
\text { Collaboration }\end{array}$ \\
\hline 5 & $\begin{array}{l}\text { Contra Costa County: } \\
50 \text { Douglas }\end{array}$ & - & Yes & Yes & $\begin{array}{c}\text { Summer } \\
2005\end{array}$ & $\begin{array}{l}\text { DOD Western Grid Energy Study } \\
\text { Collaboration }\end{array}$ \\
\hline 6 & Echelon & & Yes & Yes & $\begin{array}{l}\text { Summer } \\
2005\end{array}$ & Outreach to Kenmark Controls \\
\hline 7 & $\begin{array}{l}\text { Fremont Unified } \\
\text { School District }\end{array}$ & - & - & Yes & $\begin{array}{l}\text { From } \\
2004\end{array}$ & $\begin{array}{l}\text { Recruited by LBNL and PG\&E Account } \\
\text { Representative }\end{array}$ \\
\hline 8 & $\begin{array}{l}\text { Gilead Science: } \\
300 \text { Lakeside Dr. }\end{array}$ & - & - & Yes & No & $\begin{array}{l}\text { Recruited by LBNL and PG\&E Account } \\
\text { Representative }\end{array}$ \\
\hline 9 & $\begin{array}{l}\text { Gilead Science: } \\
\text { 342 Lakeside Dr. }\end{array}$ & - & - & Yes & $\begin{array}{l}\text { From } \\
2004 \\
\end{array}$ & $\begin{array}{l}\text { Recruited by LBNL and PG\&E Account } \\
\text { Representative }\end{array}$ \\
\hline 10 & $\begin{array}{l}\text { Gilead Science: } \\
\text { 357 Lakeside Dr. }\end{array}$ & - & - & Yes & $\begin{array}{l}\text { From } \\
2004\end{array}$ & $\begin{array}{l}\text { Recruited by LBNL and PG\&E Account } \\
\text { Representative }\end{array}$ \\
\hline 11 & IKEA & - & - & Yes & No & Outreach to C\&C Controls \\
\hline 12 & $\begin{array}{l}\text { LBNL: Oakland } \\
\text { Scientific Facility }\end{array}$ & - & - & Yes & No & Recruited by LBNL \\
\hline 13 & Oracle & - & - & Yes & $\begin{array}{l}\text { Summer } \\
2005\end{array}$ & SVLG Contact \\
\hline 14 & Target & - & - & Yes & $\begin{array}{c}\text { Summer } \\
2005\end{array}$ & $\begin{array}{l}\text { National Conference on Building } \\
\text { Commissioning Contact }\end{array}$ \\
\hline 15 & $\begin{array}{l}\text { United States Postal } \\
\text { Service }\end{array}$ & $\begin{array}{l}\text { No - Too } \\
\text { busy }\end{array}$ & Yes & Yes & $\begin{array}{l}\text { Summer } \\
2005\end{array}$ & AB970 \\
\hline 16 & 300 Capital Mall & - & Yes & No & No - SMUD & SMUD Retro-commissioning Study Site \\
\hline 17 & Albertsons & Yes & Yes & No & No - DA & AB970 and FEMP collaboration \\
\hline 18 & Cal EPA & - & Yes & No & No - DA & PIER Ventilation Study Site \\
\hline 19 & $\begin{array}{l}\text { CANMET Energy } \\
\text { Technology Centre }\end{array}$ & - & Yes & $\begin{array}{l}\text { No - out } \\
\text { of state }\end{array}$ & - & LBNL Research Review Collaboration \\
\hline 20 & Cisco Systems & - & Yes & No & No - DA & $\begin{array}{l}\text { ASHRAE XML Meeting - Anaheim, } \\
2004\end{array}$ \\
\hline 21 & $\begin{array}{l}\text { GSA San Francisco } \\
\text { Federal Building }\end{array}$ & - & Yes & No & No - DA & $\begin{array}{l}\text { AB970, GSA Energy and Maintenance } \\
\text { Network (GEMnet) Collaboration }\end{array}$ \\
\hline 22 & $\begin{array}{l}\text { GSA National } \\
\text { Archives \& Records } \\
\text { Administration }\end{array}$ & - & Yes & No & No - DA & $\begin{array}{l}\text { AB970, GSA Energy and Maintenance } \\
\text { Network (GEMnet) Collaboration }\end{array}$ \\
\hline 23 & $\begin{array}{l}\text { GSA Oakland Federal } \\
\text { Building }\end{array}$ & Yes & Yes & No & No - DA & $\begin{array}{l}\text { AB970, GSA Energy and Maintenance } \\
\text { Network (GEMnet) Collaboration }\end{array}$ \\
\hline 24 & Kadant Grantek & - & Yes & $\begin{array}{l}\text { No - out } \\
\text { of state }\end{array}$ & - & \\
\hline 25 & $\begin{array}{l}\text { Monterey Commerce } \\
\text { Center }\end{array}$ & - & Yes & No & $\begin{array}{c}\text { No - less } \\
\text { than } 200 \mathrm{~kW}\end{array}$ & Outreach to Kenmark Controls \\
\hline 26 & OSISoft & - & Yes & $\begin{array}{l}\text { No }- \text { Too } \\
\text { busy }\end{array}$ & No & $\begin{array}{l}\text { Performance Monitoring Technology } \\
\text { Firm }\end{array}$ \\
\hline 27 & UC Santa Barbara & Yes & Yes & No & No - DA & $\begin{array}{l}\text { AB970, PIER Energy Information Case } \\
\text { Study Site }\end{array}$ \\
\hline 28 & Roche Palo Alto & Yes & Yes & No & $\begin{array}{l}\text { No - Palo } \\
\text { Alto Muni }\end{array}$ & AB970, PIER Infotility Case Study Site \\
\hline
\end{tabular}

DA: Direct Access 
Table 2-3 lists a sample of the sites which were contacted but declined to participate, why they declined to participate in the Auto-CPP study and how they were initially contacted. This information is provided because these sites may be re-contacted in future Automated-CPP efforts, primarily because developments in new Internet technology may address previous barriers blocking the recruitment of these sites into the program.

The sites that declined to participate had three main reasons: 1) they did not have the financial and labor resources to participate, 2) concerns about the Internet relay installation possibly weakening their intranet's security, and 3) concerns regarding capabilities of their EMCS and resources to upgrade controls. The second concern regarding security lead to the development of the CLIR box, explained below. Some sites were ready to participate in August. However, if they had not signed on to the study prior to August, they were not admitted to the pilot due to the time it takes to get each site's automation ready and tested for a CPP event.

Table 2-3: Examples of Sites Pursued and Reasons Unable to Participate in Auto-CPP

\begin{tabular}{|c|c|c|c|c|}
\hline Site & Type & $\begin{array}{c}\text { Reason of } \\
\text { Declination }\end{array}$ & Contact Method & $\begin{array}{c}\text { CPP Program } \\
2005\end{array}$ \\
\hline 1 & City government & No DR capability & Outreach by LBNL & Yes \\
\hline 2 & County government & Too busy. & $\begin{array}{l}\text { DOD Western Grid Energy Study } \\
\text { Collaboration }\end{array}$ & Yes \\
\hline 3 & State government & No & & \\
\hline 4 & $\begin{array}{l}\text { Governmental bio- } \\
\text { tech research lab }\end{array}$ & $\begin{array}{l}\text { Not enough resources, } \\
\text { mere DR potential. }\end{array}$ & Outreach by LBNL & No \\
\hline 5 & IT & Security & Recruited by LBNL & \\
\hline 6 & IT & Security & SVLG Contact, already on CPP & \\
\hline 7 & IT & Too busy & Already on CPP & Yes \\
\hline 8 & IT developer & Security & Already on CPP & Yes \\
\hline 9 & Software developer & No resources & SVLG Contact & \\
\hline 10 & $\begin{array}{l}\text { Electronics } \\
\text { Manufacturer }\end{array}$ & Ready too late & Already on CPP & Yes \\
\hline 11 & $\begin{array}{l}\text { Hi-tech } \\
\text { manufacturer }\end{array}$ & Security & $\begin{array}{l}\text { Recruited by LBNL and PG\&E } \\
\text { account representative }\end{array}$ & Yes \\
\hline 12 & $\begin{array}{l}\text { Bio-tech } \\
\text { manufacturer }\end{array}$ & Financial Problems & Already on CPP & Yes \\
\hline 13 & $\begin{array}{l}\text { Measurement } \\
\text { devise manufacturer }\end{array}$ & DA & Outreach by LBNL & No \\
\hline 14 & $\begin{array}{l}\text { Pharmaceutical } \\
\text { manufacturer }\end{array}$ & Do not have resources & Already on CPP & Yes \\
\hline 15 & $\begin{array}{l}\text { Aeronautics } \\
\text { manufacturer }\end{array}$ & Security & SVLG Contact, already on CPP & Yes \\
\hline 16 & Retail store & Not enough resources & & No \\
\hline 17 & Retail store & Does not see value in CPP & Recruited by LBNL & No \\
\hline 18 & $\begin{array}{l}\text { Food trading } \\
\text { company }\end{array}$ & No EMCS & $\begin{array}{l}\text { Quantum Consulting, already } \\
\text { on CPP. }\end{array}$ & Yes \\
\hline 19 & Packaging service & Manual DR & $\begin{array}{l}\text { Quantum Consulting, already } \\
\text { on CPP. }\end{array}$ & Yes \\
\hline
\end{tabular}




\subsection{Test Preparation}

\section{Control and Communication System Configuration}

All participants were responsible for reviewing and meeting the "2005 Automated Critical Peak Pricing Pilot Participation Requirements" (Appendix A). LBNL provided the participants either the web-service program source code or Internet relay device depending on the connectivity options they chose (see Section 2.3 for details on the options). The participants agreed to work with their controls vendor or in-house staff to modify their system to be able to retrieve the XML signal or receive a control signal, and initiate an automated demand response. Once the Auto-CPP system setup was completed, LBNL published a XML electric price level signal via the Internet that contained information to represent electricity prices for the CPP event days. The Participant was able to override the test and "opt out" if needed.

\section{Data Collection}

LBNL collected various types of data to evaluate the demand savings and changes in building systems and conditions. For all the participating sites, LBNL collected 15minute whole building interval power data. A minimum of ten days of data prior to each CPP event was required to develop a baseline model. LBNL also collected HVAC, control, communications, energy, and other building-related time-series data relevant to their demand response strategies. The data collection methods are described in Section XXX. Additional information about the effectiveness of the demand response strategies and issues that arose as a result of the tests was obtained by interviewing the responsible building engineer after each Auto-CPP test was completed. Appendix C documents the raw results obtained from the post-test surveys.

\subsection{Automated Demand Response System Description}

The automated demand response system uses the public Internet and private corporate and government intranets to communicate CPP event signals that initiate reductions in electric load in commercial buildings. The CPP signals are received by energy management and control systems which perform pre-determined demand response strategies at the appropriate times. This section describes this system's technical details.

The control and communications infrastructure used in the 2005 pilot was developed under the direction of LBNL over a three-year period. The system, known as the DR Automation Server, is now in its second generation of development. The DR Automation Server used in the 2005 pilot was designed to provide levels of security, availability and scalability necessary for "mission-critical" systems used for financial transactions.

The DR Automation Server publishes a computer-readable, variable CPP-level signal on a Web services server, using the meta-language, XML (Extensible Markup Language). Each of the participating facilities monitor the common CPP-level signal using Web services client applications and automatically curtail site-specific electric loads when the CPP level increases above predetermined thresholds. The system operates without human intervention. A web-based DR Automation Server (Figure 2-2) was used by LBNL and Akuacom staff to monitor each site's participation in the Auto-CPP events. 


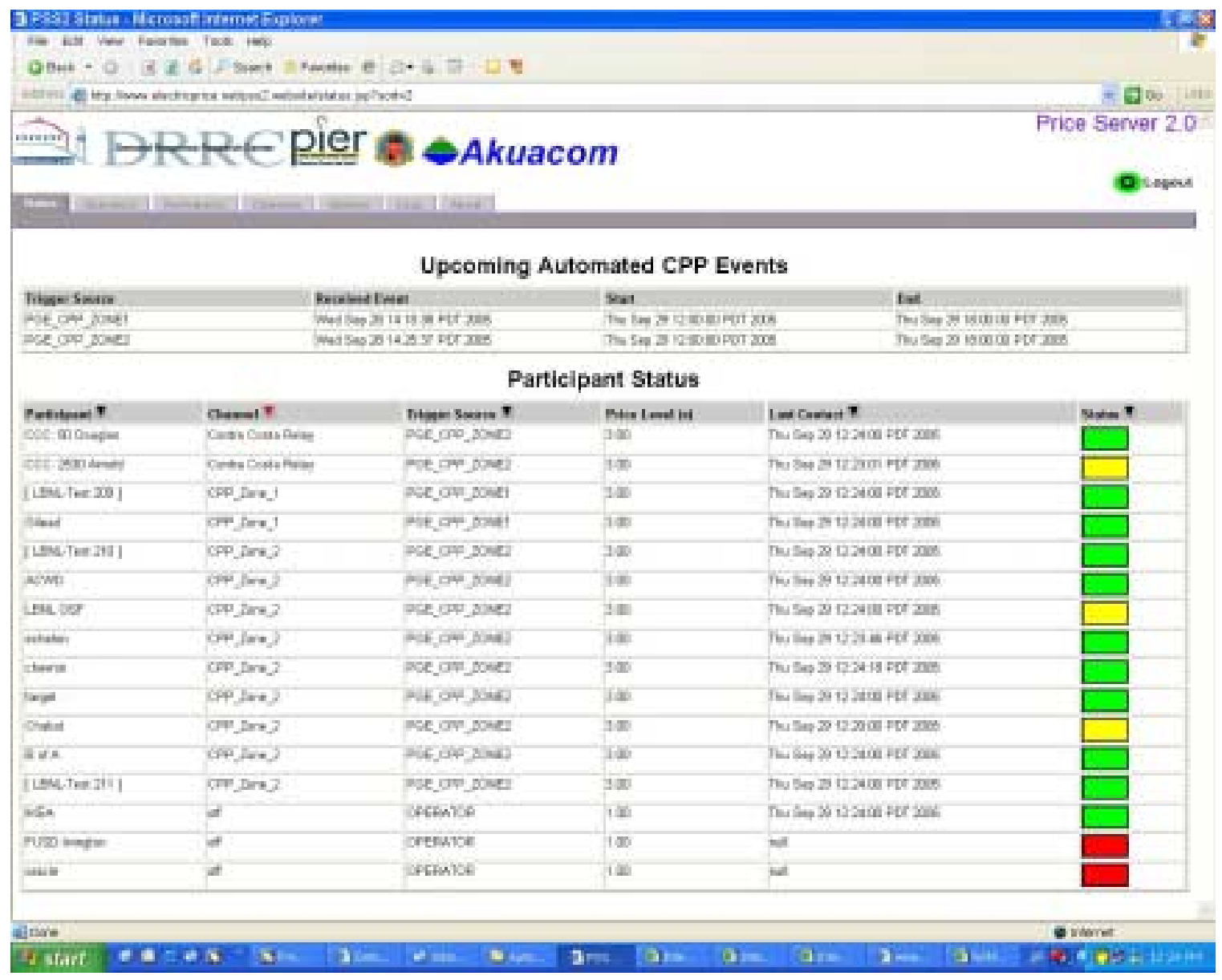

Figure 2-2: Demand Response Automation Server Web Interface

This section provides an overview of the Auto-CPP technologies used in 2005. Three different methods (Internet gateways, Internet relays and CLIR Boxes) were used as the communication interface to the control systems at each building to enable Auto-CPP.

\section{Internet Gateway}

An Internet gateway is a device used in building telemetry systems to provide several functions. First, it physically connects two otherwise incompatible networks (i.e., networks with different protocols) and allows data to pass between them. Second, it provides translation and usually abstraction of messages passed between two networks. Third, it often provides other features such as data logging, and control and monitoring of input/output ( $\mathrm{I} / \mathrm{O})$ points. Internet gateways typically connect the Internet communication protocol (TCP/IP) to the protocol of a given EMCS. This means that a different Internet gateway type is usually required to communicate with each different EMCS brand or product line. Internet gateways are not available for all EMCS. An Internet gateway can take several forms: 1) a PC with software and adapter cards that connect it to both the EMCS and the Internet, or 2) an embedded device that has the 
network adapters and network connection software packaged in a dedicated embedded device that can be mounted in a panel.

Use of the Internet gateway connection method is not possible if the prospective buildings and organizations lack either of the following key attributes: 1) an Internet Gateway (connects the EMCS to the Internet that enables telemetry) and 2) Computer programming skills that would enable them to create custom "Price Client" software. Overcoming these impediments can be daunting. The feasibility of adding an Internet gateway to a legacy EMCS varies depending on the EMCS manufacture, the protocol, the EMCS vintage and other factors. For many legacy systems, adding an Internet gateway (if possible) can cost between $\$ 5,000$ and $\$ 15,000$.

Even if a given site had an Internet gateway, most typical commercial buildings could not participate due to their lack of in-house computer programming skills. Outsourcing this programming was generally not an option due to the unique skills required. Both $\mathrm{XML} / \mathrm{Web}$ services programming skills and domain knowledge of the existing EMCS are required to create custom "Polling Client" software. In addition, outsourcing the creation of the price client software could cost between $\$ 5,000$ and $\$ 10,000$.

Costs to outfit typical commercial buildings using the Internet gateway method could be between $\$ 10,000$ and $\$ 25,000$ for the necessary hardware and software. In addition, there is little consistency between buildings because different Internet gateways are required for each different EMCS protocol, many of which are proprietary and not interoperable with more open systems. Furthermore, Internet gateways may not be available for some EMCS.

\section{Internet Relay}

Rather than require all sites to have an Internet gateway, another connectivity option was provided for the 2004 and 2005 tests. If desired, LBNL provided participating sites with a low-cost Internet relay. An Internet relay is a device with relay contacts that can be actuated remotely over a LAN, WAN or the Internet using Internet Protocols (IP). The Internet is based on a standard protocol (TCP/IP) and all EMCS can sense the state of relay contact closures (regardless of their particular EMCS protocol). Because of this, Internet relays can be used on virtually any commercial building that has a standard connection to the Internet. Internet connectivity directly to the EMCS is not required.

The project "standard" Internet relay (ADAM-6060) cost less than \$200 each and were used to remotely signal 10 of the sites for the Auto-CPP tests. Instead of converting $\mathrm{XML}$ messages to the native EMCS protocol, the Internet relay simply closes relay contacts, which were read as digital inputs by EMCS controllers. The in-house staff programmed the EMCS to curtail loads based on the state of the Internet relay. Rather than require the sites to have in-house computer programmers, the polling client software was developed and deployed by the programmers at the company that created the DR Automation Server software, Akuacom.

Some sites chose to create and deploy their own polling client and logic software and used it to control their own Internet relays (as opposed to sites that used project "standard" Internet relays controlled by Akuacom price client and logic software). These 
sites hosted the price client and logic software wherever they desired and had the additional benefit of customizing the logic software, if desired.

The simplicity of the Internet relay architecture made it possible for many sites to participate in the 2005 Auto-DR tests that would not have been able to do so otherwise. However, there are some impediments to use of the Internet relay:

1. Requires coordination with the information technology (IT) group at the site. The IT group must make some minor configuration changes to the corporate firewall to enable the DR Automation Server to push messages to the Internet relay.

2. The firewall re-configuration is a task that may take 1-3 hours plus substantial time for coordination and authorization.

3. Though practically without merit, the firewall re-configuration can be perceived as a risk to the security of the network.

\section{Client \& Logic with Integrated Relay (CLIR) Box}

The Client \& Logic with Integrated Relay (CLIR) Box is a secure, self-configuring Internet relay. The CLIR box connects an EMCS to the DR Automation Server over the site local area network (LAN) and the Internet. The CLIR Box signals the EMCS through a standard relay contact interface. The CLIR Box is self-configuring. It joins the LAN at commercial building sites without assistance required from the IT administrator. No reconfiguration of the site firewall is required. The CLIR Box is plugged into the LAN and hooked up to the EMCS. Pre-determined demand response strategies are programmed into the EMCS. The EMCS then responses to price- or contingency-based events generated in the DR Automation Server and communicated via the CLIR Box.

The CLIR Box was proven in the field to overcome impediments of the other two connection methods. At two sites that were not able to use Internet gateways or Internet relays due to reasons outlined above, CLIR Boxes were installed and functional within several hours. Although the hardware cost is currently about $\$ 800$, reduced configuration labor and increased security features make the CLIR Box the best connectivity option for most commercial participants. Additional CLIR Box development and improved installation procedures are expected to further lower the installed cost of connectivity.

Figure 2-3 shows the 2005 Auto-CPP Control and Communication System Architecture. The following text describes the chronological numbered elements of the diagram:

1. PG\&E uses their standard InterAct II system to notify the DR Automation Server of an upcoming CPP event (notification occurs day-ahead).

2. The DR Automation Server posts two pieces of information on its Web services server:

○ There is a pending event. This is posted immediately upon receipt from PG\&E at approximately 3:00 PM the day ahead.

- There is an active event of a given level. Moderate-level demand response events are posted between 12:00 - 3:00 PM. High-level demand response events are posted between 3:00 PM-6:00 PM on the day of the event. 
3. Polling clients request information each minute. Logic software determines actions based upon latest information polled from the DR Automation Server. Actions are initiated based on predetermined logic.

4. Energy management control system (EMCS) carries out predetermined demand response control commands.

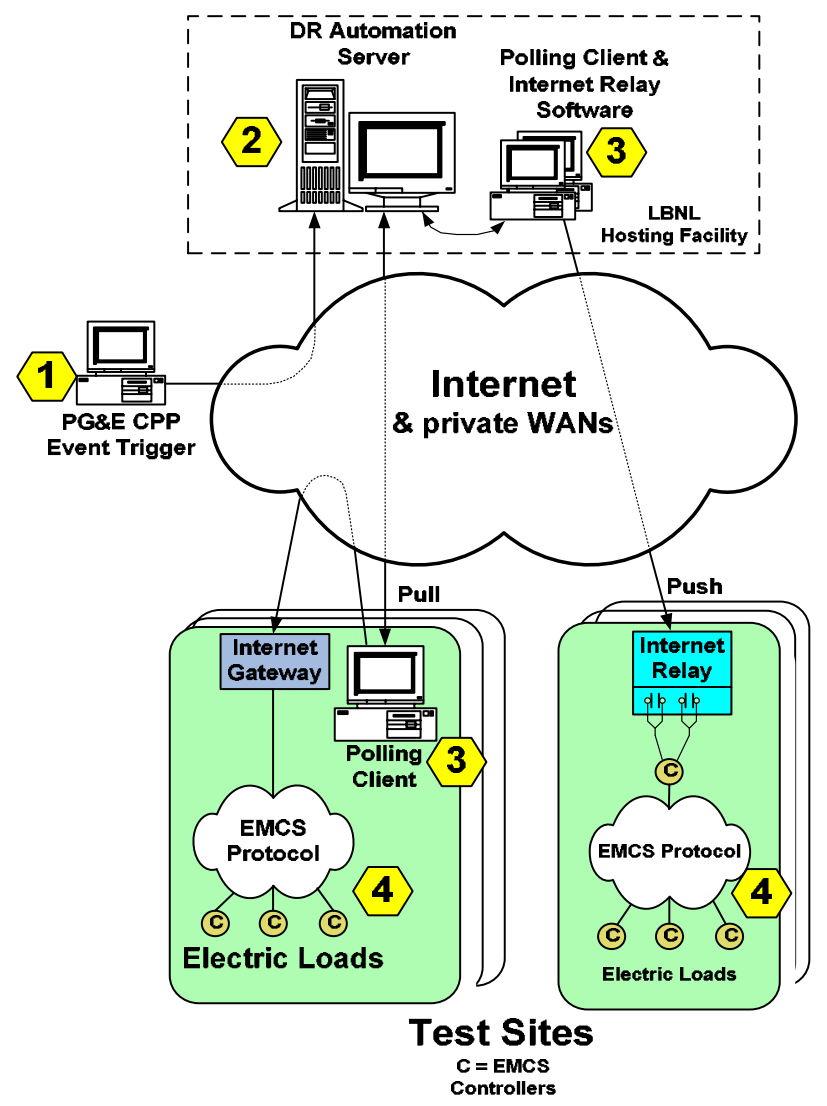

Figure 2-3: Auto-CPP Control and Communication System Architecture

The 2005 Auto-CPP tests were conducted with the three options mentioned above. The procedures to follow for each option are described below.

\section{Steps necessary for site facility staff to install an Internet gateway:}

1) Determine if a compatible Internet gateway is available for the EMCS(s) in the facility of interest.

2) If available, contact an EMCS system vendor or integrator to purchase and/or configure the gateway.

3) Connect device to Internet with an RJ-45 Ethernet plug and assign a public static IP address to the device.

4) Hook up wires between the Internet gateway and the EMCS network bus.

5) Map the desired EMCS points into the gateways so as to allow control from the Internet.

6) Write and deploy price client and logic software 


\section{Steps necessary for site facility staff to install an Internet relay:}

1) Connect device to Internet with an RJ-45 Ethernet plug and assign a public static IP address to the device.

2) Hook up wires between the Internet relay and two digital inputs on the EMCS.

3) Configure the EMCS to curtail loads when Internet relay contact(s) close per the Table 2-4. The control strategy for Level 1 and Level 2 for each site is listed in Section 3.3. Six contacts on each Internet relay allow up to 64 discrete saving levels to be sent, if desired $\left(2^{6}=64\right)$.

\section{Steps necessary for site facility staff to install a CLIR Box:}

1) Connect device to Internet with an RJ-45 Ethernet plug (public static IP address is not required. Changes to the firewall are not required). The CLIR Box is selfconfiguring.

2) Hook up wires between the CLIR Box relay and two digital inputs on the EMCS.

3) Configure the EMCS to curtail loads when CLIR Box relay contact(s) close per Table 2-4. The control strategy for Level 1 and Level 2 for each site is listed in Section 3.3. Two digital inputs are required for standard Auto-CPP. Three digital inputs are required for Auto-CPP with pre-cooling alert functionality.

Table 2-4: Function of Relay Contacts (Internet relay and CLIR Box only)

\begin{tabular}{|c|c|c|c|}
\hline $\begin{array}{c}\text { ADAM6060 } \\
\text { Relay \# }\end{array}$ & Description & $\begin{array}{c}\text { Timing When } \\
\text { Relay is "ON" }\end{array}$ & Used for: \\
\hline$\# 0$ & Moderate Price (real-time) & $\begin{array}{c}\text { Noon - 3:00 pm } \\
\text { Day of CPP Event }\end{array}$ & $\begin{array}{c}\text { Digital Input } \\
\text { Into EMCS }\end{array}$ \\
\hline$\# 1$ & $\begin{array}{c}\text { High Price (real-time) } \\
\text { Note: Relay \#1 also ON } \\
\text { in High Price mode }\end{array}$ & $\begin{array}{c}3: 00 \mathrm{pm}-6: 00 \mathrm{pm} \\
\text { Day of CPP Event }\end{array}$ & $\begin{array}{c}\text { Digital Input } \\
\text { Into EMCS }\end{array}$ \\
\hline$\# 2$ & $\begin{array}{c}\text { CPP-Event Pending } \\
\sim 3: 00 \mathrm{pm} \text { prior day } \\
\text { until end of CPP event* }\end{array}$ & $\begin{array}{c}\text { Digital Input } \\
\text { Into EMCS }\end{array}$ \\
\hline$\# 3$ & $\begin{array}{c}\text { Moderate Price (real-time) } \\
\text { Indication }\end{array}$ & Same as Relay \#0 & $\begin{array}{c}\text { Indicator Light } \\
\text { (optional) }\end{array}$ \\
\hline$\# 4$ & $\begin{array}{c}\text { High Price (real-time) } \\
\text { Indication }\end{array}$ & Same as Relay \#1 & $\begin{array}{c}\text { Indicator Light } \\
\text { (optional) }\end{array}$ \\
\hline$\# 5$ & $\begin{array}{c}\text { CPP-Event Pending } \\
\text { Indication }\end{array}$ & Same as Relay \#2 & $\begin{array}{c}\text { Indicator Light } \\
\text { (optional) }\end{array}$ \\
\hline
\end{tabular}

* If CPP days are called "back-to-back" relay \#2 and \#5 will remain ON constantly until the end of the last day.

\section{Price level and associated EMCS Behavior}

Table 2-5 shows the three discrete price levels that will be published by the DR Automation Server and the associated behavior expected from the Energy Management and Control System (EMCS). CPP events are first published on the DR Automation Server by 3:00 pm the day prior to the event. The entire schedule for the event is published at that time. 
Table 2-5: Price Levels and Associated Behaviors

\begin{tabular}{|c|c|c|c|}
\hline $\begin{array}{c}\text { Price Level } \\
\text { (Published on DR } \\
\text { Automation Server) }\end{array}$ & Description & Time Period & $\begin{array}{c}\text { Desired Behavior } \\
\text { of EMCS }\end{array}$ \\
\hline 1.0 & Normal Price & $\begin{array}{c}\text { All time except } \\
\text { CPP events }\end{array}$ & Normal Operation \\
\hline 3.0 & Moderate Price (CPP) & Noon - 3:00 PM & $\begin{array}{c}\text { Moderate Saving of } \\
\text { Electric Loads }\end{array}$ \\
\hline 5.0 & High Price (CPP) & $3: 00$ PM - 6:00 PM & $\begin{array}{c}\text { High Saving of } \\
\text { Electric Loads }\end{array}$ \\
\hline
\end{tabular}

\section{Relay contact mapping based on price Level - applicable to sites using LBNL provided Internet relays and CLIR Boxes}

Internet relays and CLIR Box relays are controlled remotely by the DR Automation Server. The relays must be near any available EMCS controller and wires into two digital inputs on the controller. When both relays are OFF, the EMCS system is in "Normal" mode. If Relay $\# 0=\mathrm{ON}$, then the system is in the "Moderate" price level mode. If Relay \#0 AND Relay \#1 are both ON, then the system is in the "High" price level mode. The function of each relay contact is shown in Table 2-4.

\section{PG\&E/Itron InterAct CPP Event Scheduler}

An interface was created between the PG\&E/Itron InterAct system and the DR Automation Server. From the perspective of the InterAct system, the DR Automation Server was set-up as two "customer-zones" one in climate zone 1 and the other in climate zone 2. The DR Automation Server controls the EMCSs of each site within each zone for all of the sites in that zone. When an Auto-CPP event was called by PG\&E, InterAct sent an XML message to the DR Automation Server indicating events in one or both customer-zones. This message was sent the day ahead to the DR Automation Server. The DR Automation Server saves this message until noon the following day and then initiates the automatic demand response control at the Auto-CPP sites as planned. Upon receipt of a message from the PG\&E Interact system, the DR Automation Server controls all Auto-CPP sites within the appropriate geographic climate zone. In addition to automatic control initiated by the DR Automation Server, individual facility managers of Auto-CPP sites were notified by the InterAct system using standard e-mail and e-page messages.

\subsection{Evaluation Techniques}

\section{Baseline Model}

We developed a baseline model to estimate the demand saving from the DR strategies. The electric consumption data for each site was collected from InterAct. The actual metered electric consumption was subtracted from the baseline-modeled consumption to derive an estimate of demand savings for each 15-minute period.

Previous research recommended a weather sensitive baseline model with adjustments for morning load variations (KEMA-XENERGY, 2003). We used an outside air temperature 
regression model with a scalar adjustment for the morning load. First, the whole building power baseline is estimated using a regression model that assumes that whole building power is linearly correlated with outside air temperature (OAT). The OAT data were obtained from on-site weather stations that were monitored by the Energy Management Control System (EMCS) or Energy Information System (EIS), or from the local weather station data available from NOAA (National Oceanic \& Atmospheric Administration). Input data are 15-minute interval whole building electric demand and 15-minute interval or hourly OAT. The model is computed as;

$$
L_{i}=a_{i}+b_{i} T_{i}
$$

where $L_{i}$ is the predicted 15-minute interval electric demand for time $i$ from the previous non-CPP work days. Depending on the frequency of the available weather data, $T_{i}$ is the hourly or 15-minute interval OAT of time $i . a_{i}$ and $b_{i}$ are estimated parameters generated from a linear regression of the input data for time $i$. Individual regression equations are developed for each 15-minute interval, resulting in 96 regressions for the entire day (24 hours/day, with four 15-minute periods per hour. $i$ is from 0:00 to 23:45). To develop the baseline electric loads for the demand savings we selected 10 "non-demand response" days. These 10 baseline days were non-weekend, non-holiday Monday through Friday workdays.

Secondly, the morning power load is used to adjust the regression model. The regression model is multiplied by the average ratio between the actual demand and the predicted demand from 9:00 am to noon. The adjusted load is computed as;

$$
\begin{gathered}
L_{i}{ }_{i}=P L_{i} \\
P=\operatorname{Average}\left(M_{i} / L_{i}\right)
\end{gathered}
$$

where $L_{i}$ is the adjusted load for time $i, P$ is the calibration ratio, and $M_{i}$ is the actual demand for time $i$. The hours from 9:00 am to 11:45 am are used to calculate $P$.

Two approaches were considered when developing the baseline model: (1) an OAT regression model without a morning load shape adjustment, and (2) an average model with a morning load shape adjustment. Based on the analysis of multiple baselines using the 2004 Auto-DR tests, the OAT regression model with morning load shape adjustment generally provided a better estimate than the OAT regression model without the morning load shape adjustment. If the OAT is low in the morning and higher in the afternoon, the morning adjustment model estimate of hourly demand is likely to be lower than actual.

The demand savings estimates for most of the buildings and Auto-CPP event days are based on the baseline OAT regression model with morning load shape adjustment. The exception to this rule is that the pre-cooling sites used the OAT regression model without the morning load shape adjustment. The OAT with morning load shape adjustment estimation method may yield a negative demand savings if the baseline model predicts a baseline that is lower than the actual demand during a given 15-minute of hourly period. Negative savings are often seen after a demand response period as part of a "rebound" or recovery peak in which the HVAC or cooling systems tries to bring the thermal zones back to normal conditions.

The evaluation included quantifying the demand savings $(\mathrm{kW})$ at each site, along with the savings in whole-building power by percentage, and the demand intensity $\left(\mathrm{W} / \mathrm{ft}^{2}\right)$. The 
demand savings is calculated by subtracting the actual whole building power from its baseline demand. The demand saving percentage is defined as the percentage of savings in whole building power. The demand-saving intensity $\left(\mathrm{W} / \mathrm{ft}^{2}\right)$ is the saved demand $(\mathrm{W})$ normalized by the building's conditioned floor area (square footage).

\section{CPP Baseline}

PG\&E uses a CPP baseline for the CPP event evaluation. The CPP baseline is the average hourly load shape of the three highest consumption days in the last ten work days (excluding holidays). The baseline algorithm considers the site electric consumption from noon to $6 \mathrm{pm}$ when selecting the highest three days. CPP event days are excluded from the reference days. The CPP baseline may be lower than the actual demand if the site's demand is weather-sensitive, since a CPP day typically occurs on a day with higher outside temperatures. If the previous ten working days are cooler than the CPP day, the baseline tends to be lower. Since the CPP tariff is based on the staging price per kWh, the baseline doesn't have any financial impact.

PG\&E also develops their Demand Bidding Program (DBP) baseline using a similar procedure. The DBP baseline uses the site electric consumption from noon to $8 \mathrm{pm}$ to select the highest three days.

The 2530 Arnold whole-building baseline time-series chart for the September $22^{\text {nd }}$ event is shown in Figure 2-4. The chart shows the actual whole building power plus the LBNL whole-building power baseline and the CPP power baseline - these baselines predicts what the whole-building power would be if the demand response had not occurred. The vertical line at each baseline power data point is the standard error of the regression estimate. The vertical lines at noon, $3 \mathrm{pm}$, and $6 \mathrm{pm}$ indicates price signal changes.

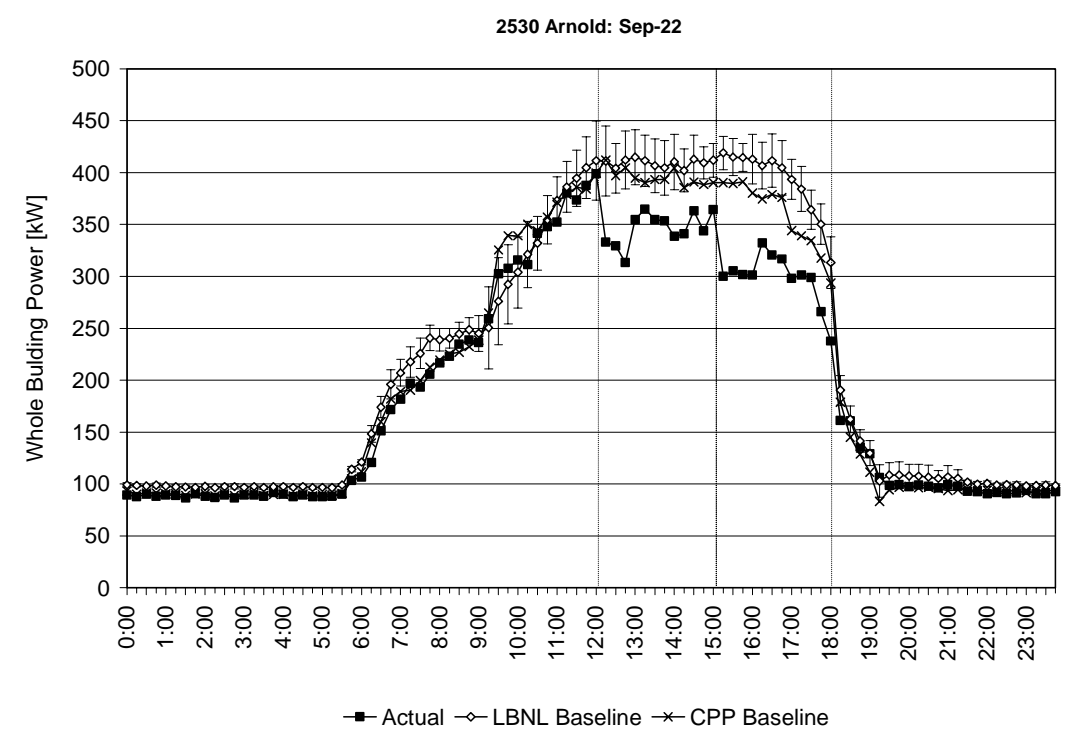

Figure 2-4: Whole-Building Baseline Time-Series Chart 


\subsection{Sub Analyses}

\section{Pre-cooling}

LBNL, the Center for the Built Environment (CBE) at the University of California, Berkeley, and Purdue University have conducted research over the past three years to investigate the technology of using building thermal mass to shift building cooling load (Xu et al 2005). The principle of pre-cooling and demand limiting is to pre-cool buildings at night or in the morning during off-peak hours, storing cooling in the building thermal mass and thereby reducing cooling loads during the peak periods. Savings are achieved by reducing on-peak energy and demand charges. The potential for utilizing building thermal mass for load shifting and peak demand reduction has been demonstrated in a number of simulation, laboratory, and field studies.

The previous studies found that a simple demand limiting strategy performed well in the test building. We found it was important to manage the afternoon demand response by ramping up the zone temperature set points rather than stepping them up. Simulation of the various reset strategies demonstrated that the exponential temperature reset strategy for the thermal mass discharge period is the best of all the three thermal mass discharge strategies studied. The simulation results indicate that pre-cooling has a greater impact on reducing air-conditioning-related peak period electrical loads than just raising the zone temperatures during the peak period.

As a subset of Auto-CPP 2005 tests, LBNL conducted additional tests to determine how thermal mass can be discharged more efficiently and more smoothly with no rebound and how to determine the metrics of the building thermal mass and estimate the load reduction potential. LBNL OSF was selected for this study as an example of a lightweight office building with $100 \%$ window to wall ratio, and Chabot as an example of a heavy mass museum with modest direct solar heat gain.

\section{Occupant Surveys}

As part of the pre-cooling collaboration between LBNL and CBE, an online real-time comfort survey was conducted to determine the actual comfort reaction to the two precooling test sites as well as at the Echelon building. The results of the comfort surveys in the previous tests indicate that occupant comfort was maintained in the pre-cooling tests as long as the room temperatures were between 70 and $76^{\circ} \mathrm{F}$.

\section{Indoor Environmental Quality Study in Retail Store}

LBNL began discussing the possibility of including a Target retail store as a result of discussions between LBNL and Target concerning the costs and benefits of commissioning. Target's energy managers were interested in evaluating potential energy savings from reducing ventilation because of the premise that Title 24 requires higher than needed ventilation. If during a demand response event we find that there is no negative impact to occupants from pollutants, there may be a possibility to reduce ventilation in other stores. In order to explore this concept, an indoor environmental quality study was conducted at the Target store participating in the Auto-CPP tests (Hotchi, Hodgson and Fisk 2006). California Title 24 requires outdoor air ventilation at $0.25 \mathrm{cfm} / \mathrm{ft}^{2}$ for retail. The latest version of Title 24 allows for reduction to $0.20 \mathrm{cfm} / \mathrm{ft}^{2}$ 
if $\mathrm{CO} 2$ control is added that will increase ventilation if $\mathrm{CO} 2$ levels increase. ASHRAE 2004, Ventilation for Acceptable Air Quality Guideline provides an IAQ Procedure that recognizes that ventilation rate procedures may not apply to all occupancy types. The IAQ Procedure allows an "engineered" system that provides acceptable air quality with ventilation rates other than the rates in the prescriptive table.

One purpose of this sub-study was to evaluate if outside air ventilation less than the ASHRAE Guideline prescriptive method for retail of $0.23 \mathrm{cfm} / \mathrm{ft}^{2}$ and the California Title 24 requirement of $0.25 \mathrm{cfm} / \mathrm{ft}^{2}$ can maintain acceptable air quality. The previous ASHRAE Guideline prescriptive method required $0.30 \mathrm{cfm} / \mathrm{ft}^{2}$ ventilation. Target believes that $0.15 \mathrm{cfm} / \mathrm{ft}^{2}$ maintains acceptable air quality in their environment, and there is significant energy savings potential operating at lower ventilation rate. For example, the reduced ventilation rate in California reduces cooling loads on a typical Target store by 24 tons or about $22 \mathrm{~kW}$. With 200 stores in California, reduced ventilation could result in a demand reduction of $4.4 \mathrm{MW}$. In almost all other states, Target Store ventilation is based on ASHRAE ventilation standards and they have not experienced air quality issues. In high humidity areas, lower outdoor air quantities provide better air quality over the long run because humidity and moisture caused by excess outdoor air have greater potential for poor air quality in the building.

Target Corporation agreed to evaluate demand response measures during the summer of 2005 at their store in Hayward, CA. Due to the near absence of data on indoor pollutant concentrations in retail environments, we were unable to predict whether temporary increases in indoor pollutant levels were likely to exceed typical values for other nonresidential buildings or guidelines for short-term exposures to volatile organic compounds (VOCs) including formaldehyde. Thus, we designed this pilot study to determine how demand response in the Target Hayward store, accomplished by shutting off a portion of the rooftop air-handling units, would affect the outdoor air ventilation rates and the concentrations of VOC air contaminants in the store's sales area. 


\section{Auto-CPP Site Characteristics}

\subsection{Site Profiles}

This section describes the fifteen sites that participated in the Auto-CPP pilot during 2005. Table 3-1 lists the site name, location, CPP zone, building use, floor space, and peak electric demand in summer 2005. The participant buildings include ten office buildings, a museum, a high school, two retail stores, and a postal service facility. Some office buildings contain laboratories or data centers.

Table 3-1: Summary of Site Information

\begin{tabular}{|c|c|c|c|c|c|c|c|c|}
\hline \multirow{2}{*}{ Site Name } & \multirow{2}{*}{ Short Name } & \multirow{2}{*}{ Location } & \multirow{2}{*}{\begin{tabular}{|l|} 
CPP \\
Zone \\
\end{tabular}} & \multirow{2}{*}{ Building Use } & \multirow{2}{*}{\begin{tabular}{c|} 
\# of \\
Bldg
\end{tabular}} & \multicolumn{2}{|c|}{ Floor Space } & \multirow{2}{*}{$\begin{array}{c}\text { Peak } \\
\text { Load kW } \\
\end{array}$} \\
\hline & & & & & & Total & Conditioned & \\
\hline $\begin{array}{l}\text { Alameda County Water } \\
\text { District, Headquarter }\end{array}$ & ACWD & Fremont & 2 & Office, lab & 1 & 51,200 & 51,200 & 347 \\
\hline $\begin{array}{l}\text { Bank of America, } \\
\text { Concord Technology } \\
\text { Center }\end{array}$ & B of $A$ & Concord & 2 & $\begin{array}{l}\text { Office, data } \\
\text { center }\end{array}$ & 4 & 616,000 & 708,000 & 5680 \\
\hline $\begin{array}{l}\text { Chabot Space and } \\
\text { Science Center, Building } \\
1 \& 2\end{array}$ & Chabot & Oakland & 2 & Museum & 2 & 86,000 & 86,000 & 333 \\
\hline $\begin{array}{l}\text { Contra Costa County, } \\
2530 \text { Arnold }\end{array}$ & 2530 Arnold & Martinez & 2 & Office & 1 & 131,000 & 131,000 & 528 \\
\hline $\begin{array}{l}\text { Contra Costa County, } 50 \\
\text { Douglas }\end{array}$ & 50 Douglas & Martinez & 2 & Office & 1 & 90,000 & 90,000 & 422 \\
\hline $\begin{array}{l}\text { Echelon, San Jose } \\
\text { Headquarter }\end{array}$ & Echelon & San Jose & 2 & $\begin{array}{l}\text { Corporate } \\
\text { Headquarter }\end{array}$ & 1 & 75,000 & 75,000 & 403 \\
\hline $\begin{array}{l}\text { Fremont Unified School } \\
\text { District, Irvington High } \\
\text { School }\end{array}$ & Irvington & Fremont & 2 & Highschool & 1 & 186,000 & 186,000 & $\mathrm{~N} / \mathrm{A}$ \\
\hline $\begin{array}{l}\text { Gilead Science, } 300 \\
\text { Lakeside Dr. }\end{array}$ & Gilead 300 & Foster City & 1 & Office & 1 & 83,000 & 83,000 & N/A \\
\hline $\begin{array}{l}\text { Gilead Science, } 342 \\
\text { Lakeside Dr. } \\
\end{array}$ & Gilead 342 & Foster City & 1 & Office, Lab & 1 & 32,000 & 32,000 & 464 \\
\hline $\begin{array}{l}\text { Gilead Science, } 357 \\
\text { Lakeside Dr. } \\
\end{array}$ & Gilead 357 & Foster City & 1 & Office, Lab & 1 & 33,000 & 33,000 & 664 \\
\hline $\begin{array}{l}\text { IKEA, East Palo Alto } \\
\text { Store }\end{array}$ & IKEA & $\begin{array}{l}\text { East Palo } \\
\text { Alto }\end{array}$ & 1 & Retail & 1 & 300,000 & 300,000 & 2238 \\
\hline $\begin{array}{l}\text { Lawrence Berkeley } \\
\text { National Laboratory, } \\
\text { Oakland Scientific } \\
\text { Facility }\end{array}$ & LBNL OSF & Oakland & 2 & $\begin{array}{l}\text { Data center, } \\
\text { Office }\end{array}$ & 1 & 90,000 & 70,000 & 2189 \\
\hline $\begin{array}{l}\text { Oracle Corporation, } \\
\text { Rocklin }\end{array}$ & Oracle & Rocklin & 2 & Office & 2 & 100,000 & 100,000 & 808 \\
\hline Target, Hayward Store & Target & Hayward & 2 & Retail & 1 & 130,000 & 130,000 & 428 \\
\hline $\begin{array}{l}\text { United States Postal } \\
\text { Service, San Jose } \\
\text { Process and Distribution } \\
\text { Center }\end{array}$ & USPS & San Jose & 2 & Postal service & 1 & 390,000 & 390,000 & 1676 \\
\hline Total & & & & & 19 & $2,393,200$ & $2,465,200$ & 16,179 \\
\hline
\end{tabular}

Gilead 300, IKEA, and LBNL OSF were not enrolled in CPP in Summer 2005. Gilead 300 was not included in the demand saving analysis due to the lack of whole building interval meter data. LBNL OSF was also not included in the analysis due to lack of sub- 
metered office floor power data. Though having a whole building interval meter installed, LBNL OSF has a large data center which dominates the whole building power, and the impact of office floor demand saving was not visible in a whole building power. OSF's participation was pursued because it was also one of the demonstration sites of the precooling research.

\subsection{Auto-CPP System Architecture}

A major difference in the communication system characteristics from the 2003 and 2004 Auto-DR studies to the 2005 Auto-CPP was that the participant site had to be a PG\&E bundled customers to be in the Auto-CPP study. For the 2003 and 2004 studies, participants served by any utility or with any type of utility schedules could participate in the test. Many sites from the 2004 pilot couldn't participate in the 2005 pilot, since they were direct access customers who couldn't enroll in CPP tariff. Table 3-2 summarizes the connectivity options used by the sites. Of the fifteen participant sites, only three sites chose to program their own price client host - Echelon and USPS had participated in 2004 and had already set up their own price client host which they modified for the 2005 Auto-CPP test. Ten sites used the Internet relay to communicate with the DR Automation Server. Two sites (Irvington and Oracle) couldn't use the Internet relay during the Auto-CPP tests due to their network security concerns. These two sites utilized the CLIR Box and were able to demonstrate their demand response capabilities in an Auto-CPP test conducted after the end of the May - October CPP time period.

Table 3-2: Summary of Site Auto-CPP Connectivity

\begin{tabular}{|l|c|c|c|c|c|}
\hline \multicolumn{1}{|c|}{ Site } & $\begin{array}{c}\text { Communication } \\
\text { Method }\end{array}$ & Device & $\begin{array}{c}\text { Price Client } \\
\text { Host }\end{array}$ & $\begin{array}{c}\text { Price Client } \\
\text { Host Location }\end{array}$ & $\begin{array}{c}\text { Price Client } \\
\text { Hosted at Co-Lo }\end{array}$ \\
\hline ACWD & Relay at site & ADAM6060 & DRAS & Novato, CA & Yes \\
\hline B of A & Relay at site & ADAM6060 & DRAS & Novato, CA & Yes \\
\hline Chabot & Relay at site & ADAM6060 & DRAS & Novato, CA & Yes \\
\hline 2530 Arnold & Relay at site & ADAM6060 & DRAS & Novato, CA & Yes \\
\hline 50 Douglas & Relay at site & ADAM6060 & DRAS & Novato, CA & Yes \\
\hline Echelon & DRAS-WS & i.LON & Kenmark & San Francisco, CA & No \\
\hline Irvington & CLIR & CLIR & CLIR & Novato, CA & Yes \\
\hline Gilead 300 & Relay w/WAN & ADAM6060 & DRAS & Novato, CA & Yes \\
\hline Gilead 342 & Relay w/WAN & ADAM6060 & DRAS & Novato, CA & Yes \\
\hline Gilead 357 & Relay w/WAN & ADAM6060 & DRAS & Novato, CA & Yes \\
\hline IKEA & Relay at site & ADAM6060 & DRAS & Novato, CA & Yes \\
\hline LBNL OSF & Relay w/WAN & ADAM6060 & DRAS & Novato, CA & Yes \\
\hline Oracle & CLIR & CLIR & CLIR & Rocklin, CA & No \\
\hline Target & DRAS-WS & Canon Technologies & Target & Minesota & Yes \\
\hline USPS & DRAS-WS & Enflex & Chevron/Viron & Kansas City, KS & Yes \\
\hline
\end{tabular}

\subsection{DR Control Strategies}

The participant sites were asked to develop two levels of demand response, one for the moderate price period, and a second for the high price period. Table 3-3 summarizes each site's strategies corresponding to these levels. Most of the sites programmed their EMCS to reduce HVAC system electric loads, while some included lighting sheds. In general, the site staff made their own decisions regarding what demand response control 
strategies they would employ. LBNL consulted with sites as needed to figure out available demand response strategy options.

The major improvements of 2005 pilot are consideration of slow recovery strategies, and pre-cooling strategies. During the 2003 and 2004 tests, LBNL saw several rebound peak cases. This year, four sites programmed unique slow recovery strategies to avoid the rebound peak after the end of the demand response period. While three sites out of four programmed their HVAC equipment to slowly adjust back to the original setpoint over certain period of time, one site programmed their HVAC equipment to extend the demand response control period for two more hours, so that the end of the demand response control period coincided with the shutdown of the HVAC system for the night. It was relatively easier to mitigate the rebound peak under the 2005 Auto-CPP tests, because the CPP period ended at $6 \mathrm{pm}-$ a time when the majority of the participant sites typically stop their HVAC operation for the night.

The pre-cooling strategies were new to the Auto-CPP study. Since the 2003 and 2004 studies were based on 15-minute advance notification, there was no opportunity for precooling. CPP's day-ahead notification allowed participants to start their strategies earlier than the peak period occurs. The pre-cooling strategies were employed at Chabot and LBNL OSF. These demonstrations were part of the DRRC Demand Shifting with Thermal Mass Project, as well as the Auto-CPP pilot. The pre-cooling control strategy details are discussed in Section 4.5.

Table 3-3: Site-Specific Demand Response Strategies

\begin{tabular}{|c|c|c|c|c|}
\hline Site Name & Pre-event & Moderate Price & High Price & Slow Recovery \\
\hline ACWD & None. & $\begin{array}{l}\text { Boiler disabled. } \\
\text { CHW setpoint raised to } 50^{\circ} \mathrm{F} \text {. } \\
\text { Current limiting to } 70 \% \text {. } \\
\text { SAT increased from } 55^{\circ} \mathrm{F} \text { to } \\
65^{\circ} \mathrm{F} \text { for AHUs } 1,2,3 \\
\text { and Lab AHU. } \\
\text { DSP setpoint decreased from } \\
1.5^{\prime \prime} \text { to } 1.0^{\prime \prime} \text {. } \\
\text { Zone setpoint increased to } 75^{\circ} \mathrm{F} \text {. }\end{array}$ & $\begin{array}{l}\text { Zone setpoint increased to } \\
78^{\circ} \mathrm{F} \text {. }\end{array}$ & $\begin{array}{l}\text { Extend shed } \\
\text { control } 2 \text { hours } \\
\text { (until } 8 \text { pm). }\end{array}$ \\
\hline B of $A$ & None. & None. & $\begin{array}{l}\text { Reduce DSP from 2.2" to } \\
1.4^{\prime \prime} \text {. } \\
\text { Lock fan VFD } 3 \text { minutes } \\
\text { after the DSP reset. } \\
\text { CHW setpoint increased } \\
5^{\circ} \mathrm{F} \text { at the secondary loop. } \\
\text { Lock cooling valve } \\
\text { position at the AHU. }\end{array}$ & None. \\
\hline Chabot & $\begin{array}{l}\text { Free cooling } \\
\text { when the } \mathrm{OAT} \\
\text { is below } 62^{\circ} \mathrm{F} \\
\text { Pre-cooling } \\
\text { until noon at } \\
70^{\circ} \mathrm{F} \text { average } \\
\text { zone temp. }\end{array}$ & $\begin{array}{l}\text { Drift zone setpoint to } 74^{\circ} \mathrm{F} \text {, } \\
4 / 3{ }^{\circ} \mathrm{F} \text { each hour }\end{array}$ & $\begin{array}{l}\text { Drift zone setpoint to } 78 \mathrm{~F} \text {, } \\
4 / 3^{\circ} \mathrm{F} \text { each hour }\end{array}$ & None. \\
\hline 2530 Arnold & None. & $\begin{array}{l}\text { Zone setpoint increased } 2^{\circ} \mathrm{F} \text {. } \\
\left(76^{\circ} \mathrm{F} \text { to } 78^{\circ} \mathrm{F}\right)\end{array}$ & $\begin{array}{l}\text { Zone setpoint } 4^{\circ} \mathrm{F} \text { up. } \\
\left(80^{\circ} \mathrm{F}\right)\end{array}$ & $\begin{array}{l}\text { VAV boxes are } \\
\text { released one by } \\
\text { one over a short } \\
\text { interval. }\end{array}$ \\
\hline
\end{tabular}


Table 3-3 (continued): Site-Specific Demand Response Strategies

\begin{tabular}{|c|c|c|c|c|}
\hline Site Name & Pre-event & Moderate Price & High Price & Slow Recovery \\
\hline 50 Douglas & None. & $\begin{array}{l}\text { Zone setpoint increased } 2^{\circ} \mathrm{F} \text {. } \\
\left(76^{\circ} \mathrm{F} \text { to } 78^{\circ} \mathrm{F}\right)\end{array}$ & $\begin{array}{l}\text { Zone setpoint } 4^{\circ} \mathrm{F} \text { up. } \\
\left(80^{\circ} \mathrm{F}\right)\end{array}$ & $\begin{array}{l}\text { VAV boxes are } \\
\text { released one by } \\
\text { one over a short } \\
\text { interval. }\end{array}$ \\
\hline Echelon & None. & $\begin{array}{l}\text { Hallway lighting turned off } \\
\text { where there is ambient light } \\
\text { Daylit office lights turned off. } \\
\text { Inner office lights dimmed to } \\
20 \% \text {. }\end{array}$ & $\begin{array}{l}1 \text { of } 3 \text { RTU turned off. } \\
\text { DSP reduced from } 1.5^{\prime \prime} \text { to } \\
0.8^{\prime \prime} \\
\text { SAT increased from } 55 \text { to } \\
65^{\circ} \mathrm{F} \text {. }\end{array}$ & None. \\
\hline Irvington & $\begin{array}{l}\text { Precooling to } \\
72^{\circ} \mathrm{F} \text { until } \\
11: 50 \text { a.m. }\end{array}$ & $\begin{array}{l}\text { Raise temperature to } 78^{\circ} \mathrm{F} \text { until } \\
2: 50 \text { p.m. }\end{array}$ & $\begin{array}{l}\text { Turn off systems at } \\
\text { 2:50pm. School closes at } \\
\text { 3pm. Office areas drift. }\end{array}$ & None. \\
\hline Gilead 300 & $\begin{array}{l}\text { Shed control } \\
\text { starts at } 11 \mathrm{am} .\end{array}$ & $\begin{array}{l}\text { AHU increase SAT from } 55^{\circ} \mathrm{F} \\
\text { to } 65^{\circ} \mathrm{F} \text {. }\end{array}$ & Same as moderate price. & None. \\
\hline Gilead 342 & $\begin{array}{l}\text { Shed control } \\
\text { starts at } 11 \mathrm{am}\end{array}$ & $\begin{array}{l}\text { AHU increase SAT from } 55^{\circ} \mathrm{F} \\
\text { to } 65^{\circ} \mathrm{F} \text {. } \\
\text { Zone setpoint increase to } 75^{\circ} \mathrm{F} \\
\left(70 \sim 75^{\circ} \mathrm{F} \text { normal }\right) .\end{array}$ & Same as moderate price. & None. \\
\hline Gilead 357 & $\begin{array}{l}\text { Shed control } \\
\text { starts at } 11 \mathrm{am}\end{array}$ & $\begin{array}{l}\text { AHU SAT increased from } 55^{\circ} \mathrm{F} \\
\text { to } 65^{\circ} \mathrm{F} \text {. } \\
\text { Zone setpoint increased to } 75^{\circ} \mathrm{F} \\
\left(70 \sim 75^{\circ} \mathrm{F} \text { normal). }\right.\end{array}$ & Same as moderate price. & None. \\
\hline IKEA & None. & $\begin{array}{l}\text { Zone setpoint increased } 2{ }^{\circ} \mathrm{F} \\
\text { at each RTU. }\end{array}$ & $\begin{array}{l}\text { Zone setpoints increased } \\
\text { to } 76^{\circ} \mathrm{F} \text {. }\end{array}$ & None. \\
\hline LBNL OSF & $\begin{array}{l}\text { Zone setpoint - } \\
0 \text { to } 2^{\circ} \mathrm{F} \text { decrease } \\
\text { in the morning for } \\
\text { pre cooling. }\end{array}$ & Zone setpoint $2 \sim 6^{\circ} \mathrm{F}$ up. & $\begin{array}{l}\text { Zone setpoints increased } \\
\text { a maximum of } 6^{\circ} \mathrm{F} \text { up. }\end{array}$ & None. \\
\hline Target & $\begin{array}{l}\text { None. } \\
\text { None. }\end{array}$ & $\begin{array}{l}\text { DSP reduced } 20 \% \text { at supply fans. } \\
\text { Shut off } 3 \text { of } 12 \text { RTUs } \\
\text { in the sales area (building has } 23 \\
\text { RTUs total). } \\
\text { Shut off } 5 \text { RTUs in the sales area } \\
\text { after October } 6^{\text {th }} \text {. }\end{array}$ & $\begin{array}{l}\text { Zone setpoints increased } \\
3^{\circ} \mathrm{F} \text {. } \\
\text { Turn off every fourth } \\
\text { light fixture in the sales } \\
\text { area. }\end{array}$ & $\begin{array}{l}\text { None. } \\
\text { None. }\end{array}$ \\
\hline USPS & None. & Limit chiller demand to $80 \%$. & $\begin{array}{l}\text { Limit chiller demand to } \\
65 \% \text {. }\end{array}$ & $\begin{array}{l}\text { The chiller } \\
\text { demand limit will } \\
\text { be increased in } \\
5 \% \text { increments } \\
\text { with } 15-30 \\
\text { minutes per step } \\
\text { change }\end{array}$ \\
\hline
\end{tabular}

Table 3-4 shows the demand response strategies by major category for each building. Ten of the fifteen buildings used global temperature adjustment strategy. Throughout the previous studies, the global temperature adjustment strategy was found to be very effective and one of the least disruptive. In general, DR strategies which curtail demand for both air distribution and cooling components produce higher demand savings than the strategies which curtail only air distribution demand. Two buildings implemented lighting shed control. Most of other buildings were unable to control lighting due to lack of interface between lighting control panel and EMCS.

ACWD, B of A, Chabot, Echelon, LBNL OSF, and Target modified their DR strategies during the CPP period to improve their demand saving performance. They looked at the 
whole building power and EMCS trend data to diagnose their DR strategy operation. As a result, all of them achieved higher demand savings. Some also reduced occupant complaints.

Table 3-4: Summary of Demand Response Strategies

\begin{tabular}{|c|c|c|c|c|c|c|c|c|c|c|c|c|c|c|}
\hline & \multicolumn{12}{|c|}{ HVAC } & \multicolumn{2}{|c|}{ Light } \\
\hline & 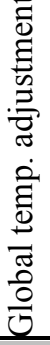 & 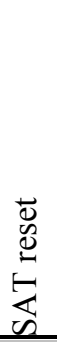 & 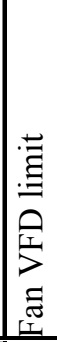 & 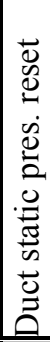 & 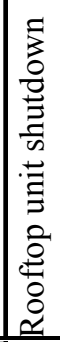 & 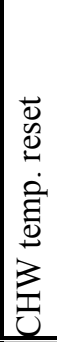 & 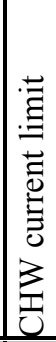 & 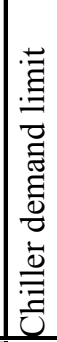 & 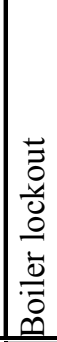 & $\begin{array}{l}00 \\
. \Xi \\
0 \\
0 \\
0 \\
0 \\
0 \\
0 \\
0\end{array}$ & 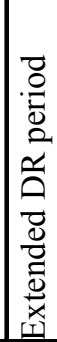 & $\begin{array}{l}\text { Dे } \\
0 \\
0 \\
0 \\
0 \\
0 \\
0 \\
0 \\
0\end{array}$ & 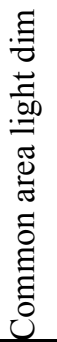 & 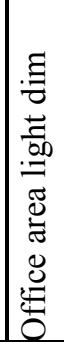 \\
\hline ACWD & $X$ & $x$ & & $x$ & & $x$ & $x$ & & $x$ & & X & & & \\
\hline B of $A$ & & & $\bar{X}$ & $\mathrm{X}$ & & $X$ & $\bar{x}$ & & & & & & & \\
\hline Chabot & $x$ & & & & & & & & & $X$ & & & & \\
\hline 2530 Arnold & $\bar{X}$ & & & & & & & & & & & $X$ & & \\
\hline 50 Douglas & $X$ & & & & & & & & & & & $\mathrm{X}$ & & \\
\hline Echelon & & $x$ & & $x$ & $\bar{x}$ & & & & & & & & $X$ & $\bar{X}$ \\
\hline Irvington & $X$ & & & & & & & & & $\mathrm{X}$ & & & & \\
\hline Gilead 300 & & $X$ & & & & & & & & & & & & \\
\hline Gilead 342 & $X$ & $X$ & & & & & & & & & & & & \\
\hline Gilead 357 & $\mathrm{X}$ & $\mathrm{X}$ & & & & & & & & & & & & \\
\hline IKEA & $X$ & & & & & & & & & & & & & \\
\hline LBNL OSF & $\mathrm{X}$ & & & & & & & & & $X$ & & & & \\
\hline Oracle & $\bar{X}$ & & & $x$ & & & & & & & & & & \\
\hline Target & & & & & $\bar{x}$ & & & & & & & & $X$ & \\
\hline USPS & & & & & & & & $x$ & & & & $x$ & & \\
\hline
\end{tabular}

\subsection{Site Measurement}

Measurement techniques were developed for each site to evaluate the six-hour Auto-CPP events. All of the participant sites were required to have at least 15-minute interval whole building electric demand data. HVAC, control, communications, energy, and other building time series data were also collected at the sites where the additional data collection was available to evaluate successfulness of the demand response strategies.

\section{Whole Building Power}

While a combination of different energy information system tools were used in the 2003 and 2004 tests, PG\&E's InterAct took a major role in the building electric demand data acquisition during the 2005 tests. Some of the participant sites in the 2003 and 2004 studies didn't have interval meters installed nor were not PG\&E customers. This year, all the participant sites were required to be on CPP tariff, and an interval meter setup was one of the requirements to be on CPP. Therefore, all the participant sites of Auto-CPP were expected to be able to access and download their whole building demand data via InterAct. 


\section{EMCS Trend Data}

EMCS trends were setup at the sites where EMCS trends had already been set up or trends were able to be set up on the EMCS. EMCS trends were used to evaluate and troubleshoot the demand response strategies. EMCS data were checked after an AutoCPP event, and minor changes were made to the demand response strategies at some sites to improve their demand saving performance and occupants comfort. Desired EMCS data trending points for DR evaluation are summarized in Table 3-5.

Table 3-5: Desired EMCS trend points for demand response analysis

\begin{tabular}{|c|c|c|}
\hline $\begin{array}{l}\text { - ELECTRIC } \\
\text { Whole building power kW } \\
\text { Power demand at each feeder } \\
\text { End-use submeter kW } \\
\text { VAV BOX } \\
\text { Zone temp } \\
\text { Zone setpoint } \\
\text { Damper position \% } \\
\text { VAV Airflow CFM } \\
\\
\text { AHU } \\
\text { Supply fan status (on/off) } \\
\text { Return fan status (on/off) } \\
\text { Supply air temp } \\
\text { Supply air temp setpoint } \\
\text { Return air temp } \\
\text { Mixed air temp } \\
\text { Outside air temp } \\
\text { OA damper position \% } \\
\text { MA damper position \% } \\
\text { Supply fan VFD\% } \\
\text { Return fan VFD\% } \\
\text { Duct static pressure }\end{array}$ & $\begin{array}{l}\text { Supply airflow CFM } \\
\text { Cooling valve position \% } \\
\text { Heating valve position \% } \\
\text { CENTRAL PLANT } \\
\text { Chiller status (on/off) } \\
\text { Cooling tons } \\
\text { Chiller kW } \\
\text { Chiller Amps (\%Amps) } \\
\text { Cooling tower fan status (on/off) } \\
\text { Chilled water supply temp } \\
\text { Chilled water supply temp setpoint } \\
\text { Chilled water return temp } \\
\text { Condenser water supply temp } \\
\text { Condenser water return temp } \\
\text { Chilled water flow GPM } \\
\text { Chilled water pump status (on/off) } \\
\text { Condenser water pump status (on/off) } \\
\text { Chilled water pump VSD\% } \\
\text { Condenser water pump VSD\% } \\
\\
\text { R ROOFTOP UNIT } \\
\text { RTU status (on/off) } \\
\text { Supply air temp }\end{array}$ & $\begin{array}{l}\text { Return air temp } \\
\text { Mixed air temp } \\
\text { Outside air temp } \\
\text { OA damper position \% } \\
\text { MA damper position \% } \\
\text { Supply fan VFD\% } \\
\text { Duct static pressure } \\
\text { Supply airflow CFM } \\
\text { BOILER } \\
\text { Boiler status (on/off) } \\
\text { Hot water Btu } \\
\text { Hot water supply temp } \\
\text { Hot water return temp } \\
\text { Hot water flow GPM } \\
\text { Hot water pump status (on/off) } \\
\text { LIGHTING } \\
\text { Lighting status (on/off) } \\
\text { D WEATHER STATION } \\
\text { Outside air temp (dry-bulb) } \\
\text { Outside air temp (wet-bulb) } \\
\text { Outside air humidity }\end{array}$ \\
\hline
\end{tabular}

\section{Outside Air Temperature Data}

Outside air temperature (OAT) data were gathered for each site to develop the OATregression baseline model. The following data sources were used;

- NOAA (National Oceanic \& Atmospheric Administration): InterAct has a realtime subscription for NOAA hourly local temperature and dew point data. Most of this data is from weather stations at nearby airports. While useful when the weather stations are near the site being evaluated, the online weather data archives can be problematic when the weather stations were not close to the site. This is especially true in the San Francisco Bay Area, where microclimates vary significantly - even within a single city.

- CIMIS (California Irrigation Management Information System): CIMIS provides hourly weather data via website (wwwcimis.water.ca.gov). Currently CIMIS has approximately 200 weather stations in California.

- Building weather station: Some buildings have a weather station at their building site and the weather data may be monitored by the building's EMCS. This can be the 
most accurate data source if the sensors are properly calibrated. However, the data must be carefully examined, since there were many cases where the weather station is poorly commissioned, or where the "OAT" temperature data is the outside air intake temperature at an AHU rather than a true outside air temperature. At 50 Douglas, PowerLight (a solar electric system provider) provides 15-minute interval onsite weather data via website which is collected at the weather station they installed at the building rooftop.

Table 3-6 lists the OAT data source used for each of Auto-CPP participant sites. The 50 Douglas weather station data was used for 50 Douglas, B of A and 2530 Arnold, as these three sites are located relatively close to each other.

Table 3-6: OAT data source by site

\begin{tabular}{|l|c|c|c|c|}
\hline \multicolumn{1}{|c|}{ Site } & City & $\begin{array}{c}\text { OAT Data } \\
\text { Source }\end{array}$ & $\begin{array}{c}\text { Weather Station } \\
\text { Location }\end{array}$ & $\begin{array}{c}\text { Distance from } \\
\text { Weather Station }\end{array}$ \\
\hline ACWD & Fremont & NOAA & Hayward Airport & 15 miles \\
\hline B of A & Concord & PowerLight & 50 Douglas (Martinez) & 5 miles \\
\hline Chabot & Oakland & CIMIS & Oakland Foothills & 2 miles \\
\hline 2530 Arnold & Martinez & PowerLight & 50 Douglas (Martinez) & 3 miles \\
\hline 50 Douglas & Martinez & PowerLight & 50 Douglas (Martinez) & 0 miles \\
\hline Echelon & San Jose & NOAA & San Jose Airport & 3 miles \\
\hline Irvington & Fremont & NOAA & Hayward Airport & 15 miles \\
\hline Gilead 342 & Foster City & NOAA & San Francisco Airport & 6 miles \\
\hline Gilead 357 & Foster City & NOAA & San Francisco Airport & 6 miles \\
\hline IKEA & East Palo Alto & NOAA & Palo Alto Airport & 1 miles \\
\hline Oracle & Rocklin & NOAA & Sacramento Airport & 18 miles \\
\hline Target & Hayward & NOAA & Hayward Airport & 5 miles \\
\hline USPS & San Jose & NOAA & San Jose Airport & 3 miles \\
\hline
\end{tabular}




\section{Project Results}

This project successfully demonstrated that automated DR is technically feasible with existing technology and buildings can provide significant levels of automated demand response within existing CPP programs. This section discusses the key results from the buildings that participated in the Auto-CPP research program. Starting with a summary overview of each site's participation in the Auto-CPP process and events, summary results for each CPP event are discussed. See Appendix B for further information and detailed event results for each site.

\subsection{Participation Summary}

This section summarizes the Automated CPP and Mock Auto-CPP events at each site, including:

- Site Preparation for Auto-CPP Participation

- Event Participation

- Post-Event Control and Communication System Troubleshooting

Site Preparation for Auto-CPP Participation

Thirteen distinct steps were taken by each site to prepare their site for full participation in the Auto-CPP tests:

1. Determine the communication method (DR Automation Server web-service or Internet relay).

2. Sign-up on CPP.

3. Complete CPP Notification Test with PG\&E.

4. CPP becomes effective.

5. Sign and send Memorandum of Understanding (MOU) to LBNL.

6. InterAct II is setup.

7. Fill out the site questionnaire.

8. Receive the communication tool kits from LBNL.

9. Assign IP address to Internet relay, or complete DR Automation Server - WS programming.

10. Complete EMCS programming for DR strategy.

11. Complete EMCS trend data log and send sample to LBNL.

12. Complete communication test with DR Automation Server.

13. Conduct 1-hour DR control test. 
A series of spreadsheets were developed and maintained in order to manage the CPP and Auto-CPP implementation steps for each site. A key spreadsheet (Table 4-1) tracks the 13 steps involved in preparing each site for Automated CPP.

Table 4-1: Auto-CPP Preparation Status Spreadsheet

\begin{tabular}{|c|c|c|c|c|c|c|c|c|c|c|c|c|c|c|c|}
\hline Site Name & $\begin{array}{l}\text { CPP } \\
\text { Zone }\end{array}$ & $\begin{array}{l}\text { Comm. } \\
\text { Method }\end{array}$ & $\begin{array}{c}\text { CPP } \\
\text { sign- } \\
\text { up }\end{array}$ & $\begin{array}{c}\text { CPP } \\
\text { notify- } \\
\text { cation } \\
\text { test } \\
\end{array}$ & \begin{tabular}{|c|} 
Next billing \\
date or \\
Expected \\
start date \\
\end{tabular} & $\begin{array}{c}\text { CPP } \\
\text { is in } \\
\text { effect }\end{array}$ & $\mathrm{MOU}$ & $\begin{array}{c}\text { InterAct } \\
\text { Set-up }\end{array}$ & $\begin{array}{c}\text { Site } \\
\text { Questi- } \\
\text { onnaire }\end{array}$ & $\begin{array}{l}\text { Comm. } \\
\text { kit sent }\end{array}$ & $\begin{array}{c}\text { IP address } \\
\text { assigned or } \\
\text { ADRS-WS } \\
\text { completed } \\
\end{array}$ & $\begin{array}{l}\text { EMCS } \\
\text { Progra- } \\
\text { mming }\end{array}$ & $\begin{array}{c}\text { Sample } \\
\text { EMCS } \\
\text { Trend }\end{array}$ & $\begin{array}{c}\text { Server } \\
\text { comm } \\
\text { test }\end{array}$ & $\begin{array}{c}\text { Control } \\
\text { Test }\end{array}$ \\
\hline ACWD & 2 & $\begin{array}{l}\text { Relay } \\
\text { at site }\end{array}$ & Yes & Yes & $9 / 2$ & Yes & Yes & Yes & Yes & Yes & $\||\|\cdot\| \cdot|\| \cdot \cdot \| \mid$ & Completed & $\begin{array}{l}\begin{array}{l}\text { Setup } \\
\text { done }\end{array} \\
\end{array}$ & Pass & Yes \\
\hline$B$ of $A$ & 2 & $\begin{array}{l}\text { Relay } \\
\text { at site }\end{array}$ & Yes & Yes & $7 / 31$ & Yes & Yes & Yes & Yes & Yes & $\||\|\cdot\| \cdot|\| \cdot \cdot \| \mid$ & Completed & \begin{tabular}{|c|} 
in \\
process
\end{tabular} & Pass & Yes \\
\hline Chabot & 2 & $\begin{array}{l}\text { Relay } \\
\text { at site }\end{array}$ & Yes & Yes & $8 / 16$ & Yes & Yes & Yes & Yes & Yes & $\||\|\cdot\| \cdot|\| \cdot \cdot \|$ & Completed & Received & Pass & Yes \\
\hline \begin{tabular}{|l|} 
CCC: \\
50 Douglas
\end{tabular} & 2 & $\begin{array}{l}\text { Relay } \\
\text { at site }\end{array}$ & Yes & Yes & $8 / 1$ & Yes & Yes & Yes & Yes & Yes & $\||\|\cdot\| \cdot\|\cdot\| \cdot \||$ & Completed & $\begin{array}{l}\begin{array}{c}\text { Setup } \\
\text { done }\end{array} \\
\end{array}$ & Pass & Yes \\
\hline $\begin{array}{l}\text { CCC: } \\
2530 \text { Arnold }\end{array}$ & 2 & $\begin{array}{l}\text { Relay } \\
\text { at site }\end{array}$ & Yes & Yes & $7 / 21$ & Yes & Yes & Yes & Yes & Yes & $\||\|\cdot\| \cdot|\| \cdot \cdot \| \mid$ & Completed & $\begin{array}{l}\text { Setup } \\
\text { done }\end{array}$ & Pass & Yes \\
\hline Echelon & 2 & \begin{tabular}{|c|}
$\begin{array}{c}\text { ADRS- } \\
\text { WS }\end{array}$ \\
\end{tabular} & Yes & \begin{tabular}{|c|}
$\begin{array}{c}\text { Wait for } \\
\text { meter }\end{array}$ \\
\end{tabular} & $9 / 16$ & & Yes & & Yes & Yes & \begin{tabular}{|l|} 
ADRS-WS \\
completed
\end{tabular} & Completed & Received & Pass & Yes \\
\hline $\begin{array}{l}\text { FUSD: } \\
\text { Centerville JH }\end{array}$ & 2 & CLIR & Yes & Yes & Started & Yes & Yes & Yes & Yes & Yes & N/A & by $8 / 29$ & & & \\
\hline $\begin{array}{l}\text { FUSD: } \\
\text { Irvington High }\end{array}$ & 2 & CLIR & Yes & Yes & Started & Yes & Yes & Yes & & Yes & N/A & by $8 / 29$ & & & \\
\hline \begin{tabular}{|l|} 
FUSD: \\
Kennedy High
\end{tabular} & 2 & CLIR & Yes & Yes & Started & Yes & Yes & Yes & Yes & Yes & N/A & by $8 / 29$ & & & \\
\hline Gilead 300 & 1 & \begin{tabular}{|c|}
$\begin{array}{c}\text { Relay } \\
\text { w/WAN }\end{array}$ \\
\end{tabular} & Yes & \begin{tabular}{|c|}
$\begin{array}{c}\text { Contract } \\
\text { in }\end{array}$ \\
\end{tabular} & $9 / 2$ & & Yes & & & Yes & $\||\|\cdot\| \cdot|\| \cdot \cdot \|$ & Completed & $\begin{array}{c}\text { in } \\
\text { process }\end{array}$ & Pass & Yes \\
\hline Gilead 342 & 1 & \begin{tabular}{|c|} 
Relay \\
w/WAN
\end{tabular} & Yes & Yes & Started & Yes & Yes & Yes & & Yes & $\||\|\cdot\| \cdot|\| \cdot|\||$ & Completed & $\begin{array}{c}\text { in } \\
\text { process }\end{array}$ & Pass & Yes \\
\hline Gilead 357 & 1 & \begin{tabular}{|c|} 
Relay \\
w/WAN \\
\end{tabular} & Yes & Yes & Started & Yes & Yes & Yes & & Yes & $\||\|\cdot\| \cdot\|\cdot\| \cdot \||$ & by $8 / 19$ & $\begin{array}{c}\text { in } \\
\text { process }\end{array}$ & Pass & \\
\hline IKEA & 1 & \begin{tabular}{|l|} 
Relay \\
at site \\
\end{tabular} & Yes & & $9 / 19$ & & Yes & & Yes & Yes & in process & $\begin{array}{l}\text { waiting } \\
\text { for IT }\end{array}$ & & & \\
\hline LBNL: OSC & 2 & \begin{tabular}{|c|} 
Relay \\
w/WAN
\end{tabular} & & & $9 / 26$ & & Half & Yes & Yes & Yes & $\||\|\cdot\| \cdot|\| \cdot \cdot \| \mid$ & Completed & Received & Pass & Yes \\
\hline \begin{tabular}{|l|} 
Oracle \\
Pleasanton
\end{tabular} & 2 & \begin{tabular}{|c|}
$\begin{array}{c}\text { ADRS- } \\
\text { WS }\end{array}$ \\
\end{tabular} & Yes & \begin{tabular}{|c|}
$\begin{array}{c}\text { Contract } \\
\text { in }\end{array}$ \\
\end{tabular} & $9 / 12$ & & Yes & & & Yes & in process & & & & \\
\hline \begin{tabular}{|l|} 
Oracle \\
Rocklin \\
\end{tabular} & 2 & CLIR & Yes & \begin{tabular}{|c|}
$\begin{array}{c}\text { Contract } \\
\text { in }\end{array}$ \\
\end{tabular} & $9 / 16$ & & Yes & Yes & Yes & Yes & N/A & & & & \\
\hline Target & 2 & \begin{tabular}{|c|}
$\begin{array}{c}\text { ADRS- } \\
\text { WS }\end{array}$ \\
\end{tabular} & Yes & Yes & $8 / 22$ & Yes & Yes & Yes & Yes & Yes & $\begin{array}{l}\text { ADRS-WS } \\
\text { completed }\end{array}$ & Completed & \begin{tabular}{|c|} 
in \\
process
\end{tabular} & Pass & Yes \\
\hline USPS & 2 & \begin{tabular}{|c|}
$\begin{array}{c}\text { ADRS- } \\
\text { WS }\end{array}$ \\
\end{tabular} & Yes & Yes & $8 / 15$ & Yes & Yes & Yes & Yes & Yes & \begin{tabular}{|c|} 
ADRS-WS \\
completed
\end{tabular} & Completed & N/A & Pass & \\
\hline
\end{tabular}

\section{Event Participation}

Table 4-2 lists all of the Auto-CPP event dates and summarizes each site's participation success (Not Ready, Opt Out, Failed, No Visible Shed, Succeeded, No Data) for each event. The weighted average of maximum outside air temperature ${ }^{4}$ is also listed for each day. Note that Gilead 300 and LBNL OSF are not included in the demand saving analysis due to a lack of valid building demand data.

${ }^{4} \sum(n T) / N ; \mathrm{T}=$ Max OAT at the site, $\mathrm{n}=\#$ of sites at the OAT region, $\mathrm{N}=\#$ of all sites. This OAT value is different from Zone 2 Average OAT which PG\&E calculates to trigger a CPP event. 
Table 4-2: Summary of Event Participation

\begin{tabular}{l||c|c|c|c|c|c|c|c|}
\hline Event Date & Aug-08 & Sep-22 & Sep-29 & Oct-06 & Oct-13 & Oct-25 & Nov-10 & Nov-15 \\
\hline $\begin{array}{l}\text { Average of } \\
\text { Max OAT }\end{array}$ & $76^{\circ} \mathrm{F}$ & $74^{\circ} \mathrm{F}$ & $89^{\circ} \mathrm{F}$ & $80^{\circ} \mathrm{F}$ & $84^{\circ} \mathrm{F}$ & $66^{\circ} \mathrm{F}$ & $68^{\circ} \mathrm{F}$ & $77^{\circ} \mathrm{F}$ \\
\hline \hline ACWD & Not ready & No data & Succeeded & Succeeded & Succeeded & Succeeded & - & - \\
\hline B of A & Not ready & Failed (2) & Succeeded & No data & Not visible & Succeeded & - & - \\
\hline Chabot & Not ready & Not visible & Succeeded & Not visible & Succeded & Opt out & - & - \\
\hline 2530 Arnold & Succeeded & Succeeded & Succeeded & Succeeded & Succeeded & Succeeded & - & - \\
\hline 50 Douglas & Succeeded & Failed (3) & Failed (3) & Failed (3) & Failed (3) & Succeeded & - & - \\
\hline Echelon & Not ready & Succeeded & Succeeded & Succeeded & Succeeded & Succeeded & - & - \\
\hline Irvington & Not ready & Not ready & Not ready & Not ready & Not ready & Not ready & - & Failed (3) \\
\hline Gilead 300 & Not ready & No data & No data & No data & No data & No data & - & - \\
\hline Gilead 342 & Not ready & Succeeded & Succeeded & Succeeded & Succeeded & Succeeded & - & - \\
\hline Gilead 357 & Not ready & Opt out & Succeeded & Succeeded & Not visible & Succeeded & - & - \\
\hline IKEA & Not ready & Not ready & Not ready & Not ready & Succeeded & Succeeded & - & - \\
\hline LBNL OSF & Not ready & No data & No data & No data & No data & Opt out & - & - \\
\hline Oracle & Not ready & Not ready & Not ready & Not ready & Not ready & Not ready & Succeeded & - \\
\hline Target & Succeeded & Succeeded & Succeeded & Succeeded & Succeeded & Succeeded & - & - \\
\hline USPS & Not ready & Failed (3) & Failed (3) & Failed (3) & Failed (3) & Failed (3) & - & - \\
\hline
\end{tabular}

The CPP program period started on May $1^{\text {st }}$ and continued until October $31^{\text {st }}$. Nine CPP events were called during the 2005 CPP program period. Since most of the participants enrolled in CPP after the end of July, they missed six CPP events that had been called before the end of July. Although many participants had enrolled in CPP, completed their systems' Auto-CPP configurations, and were fully automated in August, only a few CPP events were called after August $1^{\text {st }}$ due to cooler weather. The CPP days called after August $1^{\text {st }}$ included August $5^{\text {th }}$, August $8^{\text {th }}$, and September $29^{\text {th }}$.

Since the number of CPP days were less than expected during the full Auto-CPP testing period, PG\&E and LBNL proposed conducting additional, "mock", CPP events even though the outside air temperatures were lower than the CPP trigger threshold. All of the participants agreed to participate in the mock CPP events. Except for the trigger threshold, the mock CPP events were conducted identically to the real CPP events, including signal transaction, e-mail notification, and control and communication. The mock CPP events were conducted on September $22^{\text {nd }}$, October $6^{\text {th }}$, October $13^{\text {th }}$, and October $25^{\text {th }}$.

Two participants (Irvington and Oracle) couldn't complete their automated system configuration by the end of CPP program period due to their network security restriction (the reasons for delays of their configuration were mentioned in Section 2.1). To solve these problems, LBNL installed CLIR Box at their sites. These two sites each conducted mock CPP events (November $10^{\text {th }}$ and $15^{\text {th }}$ ) to demonstrate their control and communication capabilities. 


\section{Control and Communication Troubleshooting}

Each Auto-CPP event was reviewed for problems that could occur in the control and communication systems. There are six milestones that the "system", from the DR Automation Server to the end-use control strategy, has to meet in order for the system to work properly:

- Readiness: The system was configured and ready to be tested by the research team (Failure in this step is indicated as "Not ready" in Table 4-2).

- Approval: Organizational approval to perform demand responsive load control was granted. If the approval was not granted, the site may opt out from the event ("Opt out" in Table 4-2).

- Price Client/DR Automation Server Communication: The price client successfully obtained the correct electricity prices from the DR Automation Server (Figure 4-1 between 25 and (3). Failures to pass this milestone were generally caused by the price client server being down or overloaded ("Failed (2)" in Table 4-2).

- Internet Gateway/Internet Relay Communication: The communication was successful between the computer containing the price client and associated logic software and the Internet gateway or Internet relay located at each site (Figure 4-1 between 3 and 4 ). Failures to pass this milestone were generally caused by: a) blockages of the Internet-based command signals due to firewalls, disconnection or network reconfiguration, or b) failures in the Internet gateway or Internet relay devices themselves ("Failed (3)" in Table 4-2).

- Control of Equipment: Target equipment was controlled as planned. Target equipment included HVAC equipment, lighting and other equipment that generates electric loads. Failures to pass this milestone were generally caused by: a) HVAC equipment not responding to command signals over the EMCS network, or b) the relay physically disconnected from the control panel ("Failed (4)" in Table 4-2).

- Effectiveness: To pass this milestone, the planned demand response strategy must have been proven to effectively reduce electric demand. Effectiveness was tested by comparing the average power $(\mathrm{kW})$ saving during the test to the average standard error of the regression model. The demand response strategy was considered effective if in either or both of the moderate price and the high price period, the average power savings over the 3 -hour period was larger than the average of the standard error in the baseline model ("Not visible" in Table 4-2). 


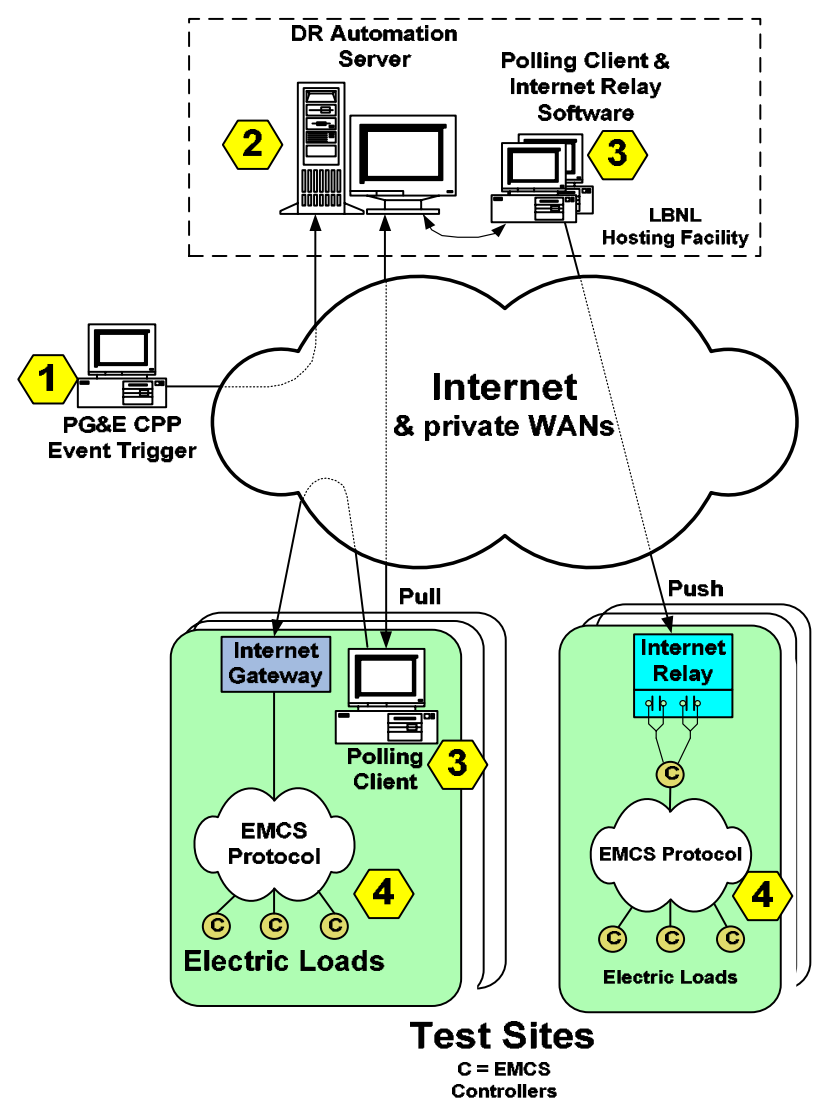

Figure 4-1: Auto-CPP Control and Communication System Architecture 


\subsection{Demand Saving Results}

This section describes the demand saving results for each CPP event. Where applicable, Auto-CPP operational findings are also mentioned.

\section{Mock CPP Event on September 22 ${ }^{\text {nd }}$}

The September $22^{\text {nd }}$ average OAT was $74^{\circ} \mathrm{F}$. Figure $4-2$ shows the aggregated demand profile of the five successful sites (ACWD is not included due to missing InterAct data). The demand savings were estimated from the LBNL baseline method. The CPP baseline is shown for comparison.

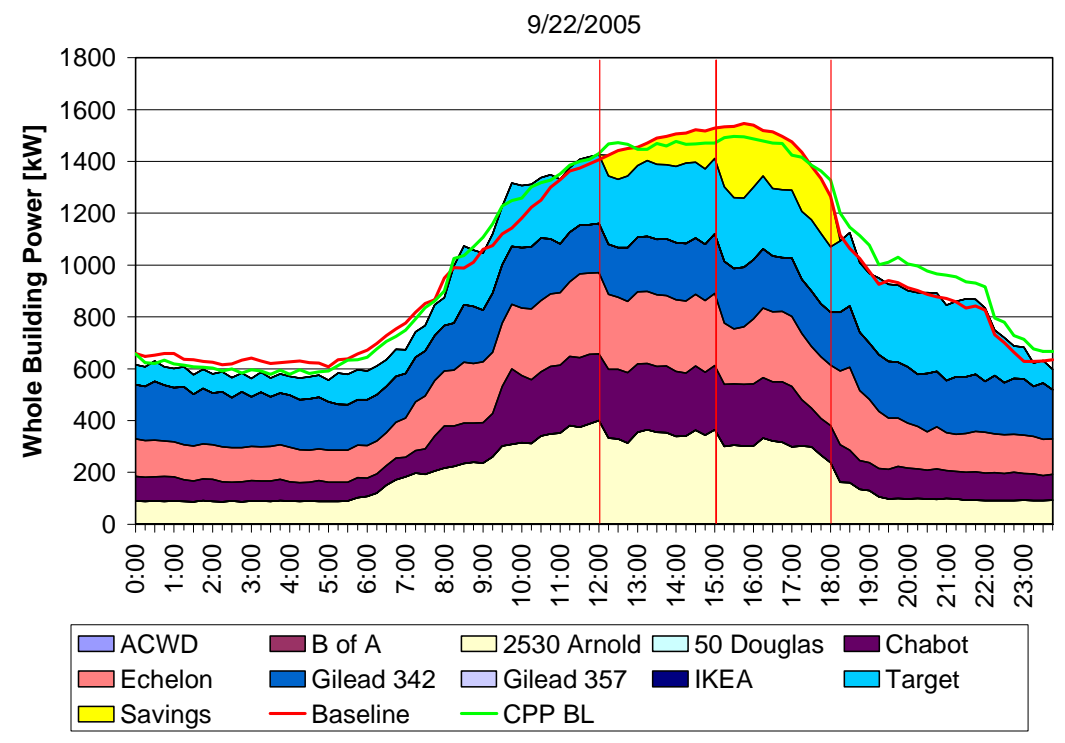

Figure 4-2: Aggregated Demand Saving, September $2^{\text {nd }}$

Table 4-3 shows the average and maximum demand savings and electricity consumption results for each 3-hour period on September $22^{\text {nd }}$. Table 4-4 provides similar information for September $29^{\text {th }}$. The maximum aggregated demand savings was $353 \mathrm{~kW}(23 \%$ of whole building power, $0.81 \mathrm{~W} / \mathrm{ft}^{2}$ ). 
Table 4-3: Average Power Saving by Price Period, September $2^{\text {nd }}$

\begin{tabular}{|c|c|c|c|c|c|c|c|c|c|}
\hline \multirow{2}{*}{ Unit } & \multirow{2}{*}{ Site Name } & \multirow{2}{*}{\multicolumn{2}{|c|}{\begin{tabular}{|c|} 
Average \\
Moderate High \\
\end{tabular}}} & \multirow{2}{*}{\multicolumn{2}{|c|}{\begin{tabular}{|c||} 
Max \\
Moderate High \\
\end{tabular}}} & \multirow{2}{*}{ Unit } & \multicolumn{3}{|c|}{ Consumption } \\
\hline & & & & & & & Moderate & High & Total \\
\hline \multirow{5}{*}{$\begin{array}{l}\text { Shed } \\
\text { kW }\end{array}$} & Chabot & $\overline{-38}$ & $\overline{-16}$ & $\overline{-23}$ & 19 & \multirow{5}{*}{$\begin{array}{l}\text { Shed } \\
\text { kWh }\end{array}$} & $\overline{-1114}$ & -47 & $\overline{-161}$ \\
\hline & 2530 Arnold & 63 & 93 & 99 & 119 & & 190 & 278 & 467 \\
\hline & Echelon & 29 & 74 & 38 & 115 & & 88 & 222 & 310 \\
\hline & Gilead 342 & 72 & 42 & 94 & 56 & & 216 & 125 & 341 \\
\hline & Target & 7 & 35 & 18 & 52 & & 21 & 105 & 126 \\
\hline \multicolumn{2}{|c|}{ Total: $\Sigma(\Delta \mathrm{P})$} & 133 & 228 & 225 & 362 & & 400 & 683 & 1083 \\
\hline \multirow{5}{*}{$\begin{array}{c}\text { WBP } \\
\%\end{array}$} & Chabot & $-18 \%$ & $-7 \%$ & $-10 \%$ & $11 \%$ & \multirow{5}{*}{$\begin{array}{c}\text { WBP } \\
\%\end{array}$} & $-18 \%$ & $-8 \%$ & $-13 \%$ \\
\hline & 2530 Arnold & $15 \%$ & $24 \%$ & $24 \%$ & $28 \%$ & & $15 \%$ & $24 \%$ & $19 \%$ \\
\hline & Echelon & $10 \%$ & $23 \%$ & $12 \%$ & $35 \%$ & & $10 \%$ & $23 \%$ & $16 \%$ \\
\hline & Gilead 342 & $25 \%$ & $16 \%$ & $33 \%$ & $21 \%$ & & $25 \%$ & $16 \%$ & $21 \%$ \\
\hline & Target & $2 \%$ & $11 \%$ & $6 \%$ & $17 \%$ & & $2 \%$ & $11 \%$ & $7 \%$ \\
\hline \multicolumn{2}{|c|}{ Total: $\Sigma(\Delta \mathrm{P}) / \Sigma(\mathrm{BP})$} & $9 \%$ & $15 \%$ & $15 \%$ & $23 \%$ & & $9 \%$ & $15 \%$ & $12 \%$ \\
\hline \multicolumn{2}{|c|}{ Average: $\Sigma(\Delta \mathrm{P} / \mathrm{BP}) / \mathrm{N}$} & $7 \%$ & $13 \%$ & $13 \%$ & $23 \%$ & & $7 \%$ & $13 \%$ & $10 \%$ \\
\hline \multirow{5}{*}{$\mathbf{W} / \mathbf{f t}^{2}$} & Chabot & $\overline{-0.44}$ & $\overline{-0.18}$ & -0.27 & 0.22 & \multirow{5}{*}{$\mathbf{W h} / \mathbf{f t}^{2}$} & -1.33 & $\overline{-0.54}$ & -1.87 \\
\hline & 2530 Arnold & 0.48 & 0.71 & 0.76 & 0.91 & & 1.45 & 2.12 & 3.57 \\
\hline & Echelon & 0.39 & 0.99 & 0.51 & 1.53 & & 1.18 & 2.96 & 4.14 \\
\hline & Gilead 342 & 2.25 & 1.31 & 2.93 & 1.76 & & 6.74 & 3.92 & 10.66 \\
\hline & Target & 0.05 & 0.27 & 0.14 & 0.40 & & 0.16 & 0.81 & 0.97 \\
\hline \multicolumn{2}{|c|}{ Total: $\Sigma(\Delta \mathrm{P}) / \Sigma(\mathrm{A})$} & 0.29 & 0.50 & 0.50 & 0.80 & & 0.88 & 1.50 & 2.39 \\
\hline \multicolumn{2}{|c|}{ Average: $\Sigma(\Delta \mathrm{P} / \mathrm{A}) / \mathbf{N}$} & 0.55 & 0.62 & 0.81 & 0.97 & & 1.64 & 1.85 & 3.49 \\
\hline
\end{tabular}

\section{Mock CPP Event on September $29^{\text {th }}$}

The September $29^{\text {th }}$ average OAT was $89^{\circ} \mathrm{F}$. Figure $4-3$ shows the aggregated demand profile of the eight successful sites.

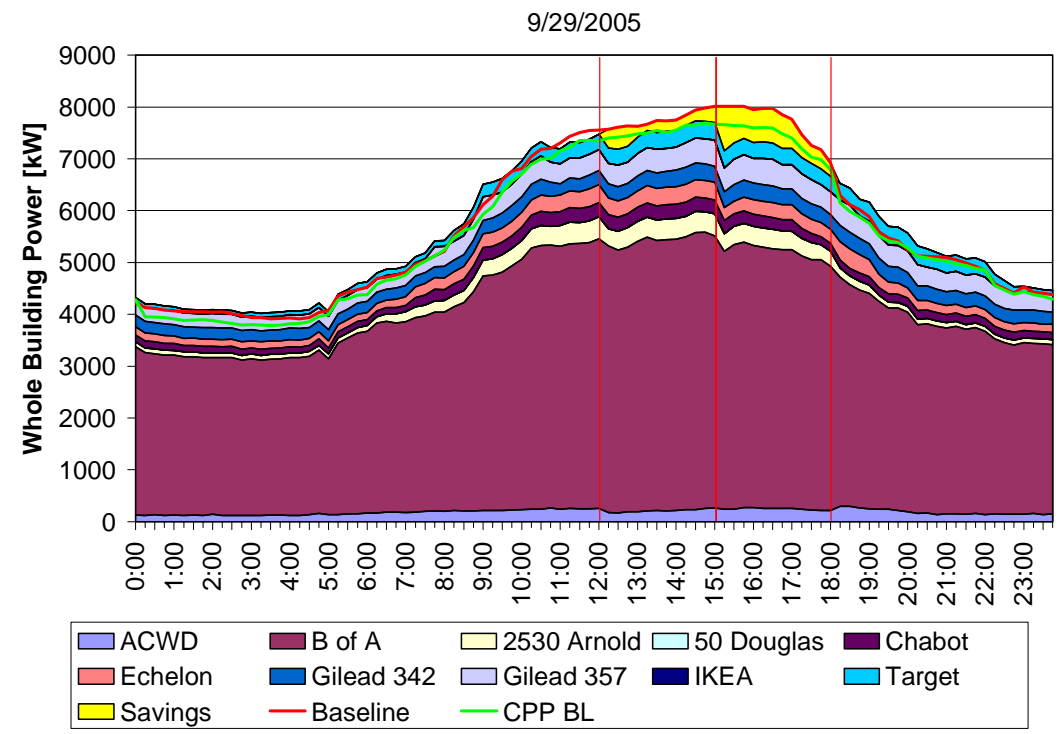

Figure 4-3: Aggregated Demand Saving, September $29^{\text {th }}$

Table 4-4 shows the average and maximum demand savings and electricity consumption results for each 3-hour period on September $29^{\text {th }}$. The maximum aggregated demand savings was $876 \mathrm{~kW}\left(11 \%\right.$ of whole building power, $\left.0.80 \mathrm{~W} / \mathrm{ft}^{2}\right)$. 
Table 4-4: Average Power Saving by Price Period, September $29^{\text {th }}$

\begin{tabular}{|c|c|c|c|c|c|c|c|c|c|}
\hline \multirow{2}{*}{ Unit } & \multirow{2}{*}{ Site Name } & \multicolumn{2}{|c|}{ Average } & \multicolumn{2}{|l|}{ Max } & \multirow{2}{*}{ Unit } & \multicolumn{3}{|c|}{ Consumption } \\
\hline & & Moderate & High & Moderate & High & & Moderate & High & Total \\
\hline \multirow{8}{*}{$\begin{array}{c}\text { Shed } \\
\text { kW }\end{array}$} & ACWD & 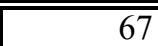 & 57 & $\overline{101}$ & 72 & \multirow{8}{*}{$\begin{array}{l}\text { Shed } \\
\text { kWh }\end{array}$} & 201 & 170 & $\overline{\overline{372}}$ \\
\hline & $B$ of $A$ & 22 & 184 & 132 & 291 & & 65 & 551 & 616 \\
\hline & Chabot & 2 & 32 & 31 & 88 & & 5 & 96 & 102 \\
\hline & 2530 Arnold & 34 & 58 & 90 & 89 & & 102 & 175 & 276 \\
\hline & Echelon & 32 & 109 & 42 & 143 & & 96 & 327 & 423 \\
\hline & Gilead 342 & 45 & 55 & 73 & 75 & & 134 & 165 & 299 \\
\hline & Gilead 357 & 48 & 62 & 94 & 150 & & 144 & 187 & 332 \\
\hline & Target & 14 & 33 & 53 & 44 & & 43 & 98 & 141 \\
\hline \multicolumn{2}{|c|}{ Total: $\Sigma(\Delta \mathrm{P})$} & 263 & 590 & 617 & 952 & & 790 & 1771 & 2561 \\
\hline \multirow{8}{*}{$\begin{array}{c}\text { WBP } \\
\%\end{array}$} & $\overline{A C W D}$ & $24 \%$ & $19 \%$ & $38 \%$ & $23 \%$ & \multirow{8}{*}{$\begin{array}{c}\text { WBP } \\
\%\end{array}$} & $24 \%$ & $19 \%$ & $21 \%$ \\
\hline & B of $A$ & $0 \%$ & $4 \%$ & $3 \%$ & $6 \%$ & & $0 \%$ & $4 \%$ & $2 \%$ \\
\hline & Chabot & $0 \%$ & $3 \%$ & $10 \%$ & $28 \%$ & & $1 \%$ & $13 \%$ & $7 \%$ \\
\hline & 2530 Arnold & $8 \%$ & $14 \%$ & $21 \%$ & $21 \%$ & & $8 \%$ & $15 \%$ & $11 \%$ \\
\hline & Echelon & $9 \%$ & $28 \%$ & $12 \%$ & $37 \%$ & & $9 \%$ & $28 \%$ & $19 \%$ \\
\hline & Gilead 342 & $13 \%$ & $15 \%$ & $19 \%$ & $20 \%$ & & $13 \%$ & $15 \%$ & $14 \%$ \\
\hline & Gilead 357 & $9 \%$ & $11 \%$ & $16 \%$ & $25 \%$ & & $10 \%$ & $12 \%$ & $11 \%$ \\
\hline & Target & $4 \%$ & $9 \%$ & $15 \%$ & $12 \%$ & & $4 \%$ & $9 \%$ & $7 \%$ \\
\hline \multicolumn{2}{|c|}{ Total: $\Sigma(\Delta \mathrm{P}) / \Sigma(\mathrm{BP})$} & $3 \%$ & $8 \%$ & $8 \%$ & $12 \%$ & & $3 \%$ & $8 \%$ & $5 \%$ \\
\hline \multicolumn{2}{|c|}{ Average: $\Sigma(\Delta \mathrm{P} / \mathrm{BP}) / \mathrm{N}$} & $9 \%$ & $13 \%$ & $17 \%$ & $21 \%$ & & $9 \%$ & $14 \%$ & $11 \%$ \\
\hline \multirow{8}{*}{$\mathbf{W} / \mathbf{f t}^{2}$} & ACWD & 1.53 & 1.29 & 2.30 & 1.63 & \multirow{8}{*}{$\mathbf{W h} / \mathbf{f t}^{2}$} & 4.58 & 3.87 & 8.44 \\
\hline & B of $A$ & 0.04 & 0.30 & 0.21 & 0.47 & & 0.11 & 0.90 & 1.00 \\
\hline & Chabot & 0.02 & 0.37 & 0.35 & 1.02 & & 0.06 & 1.12 & 1.18 \\
\hline & 2530 Arnold & 0.26 & 0.44 & 0.69 & 0.68 & & 0.78 & 1.33 & 2.11 \\
\hline & Echelon & 0.43 & 1.45 & 0.56 & 1.91 & & 1.28 & 4.36 & 5.64 \\
\hline & Gilead 342 & 1.39 & 1.72 & 2.30 & 2.36 & & 4.18 & 5.17 & 9.34 \\
\hline & Gilead 357 & 1.50 & 1.95 & 2.95 & 4.68 & & 4.51 & 5.86 & 10.37 \\
\hline & Target & 0.11 & 0.25 & 0.41 & 0.34 & & 0.33 & 0.76 & 1.09 \\
\hline \multicolumn{2}{|c|}{ Total: $\Sigma(\Delta \mathrm{P}) / \Sigma(\mathrm{A})$} & 0.23 & 0.52 & 0.54 & 0.83 & & 0.69 & 1.55 & 2.23 \\
\hline \multicolumn{2}{|c|}{ Average: $\Sigma(\Delta \mathrm{P} / \mathrm{A}) / \mathrm{N}$} & 0.66 & 0.97 & 1.22 & 1.64 & & 1.98 & 2.92 & 4.90 \\
\hline
\end{tabular}




\section{Real CPP Event on October $6^{\text {th }}$}

The October $6^{\text {th }}$ average OAT was $80^{\circ} \mathrm{F}$. Figure 4-4 shows the aggregated demand profile of the six successful sites. B of A is not included due to missing InterAct data.

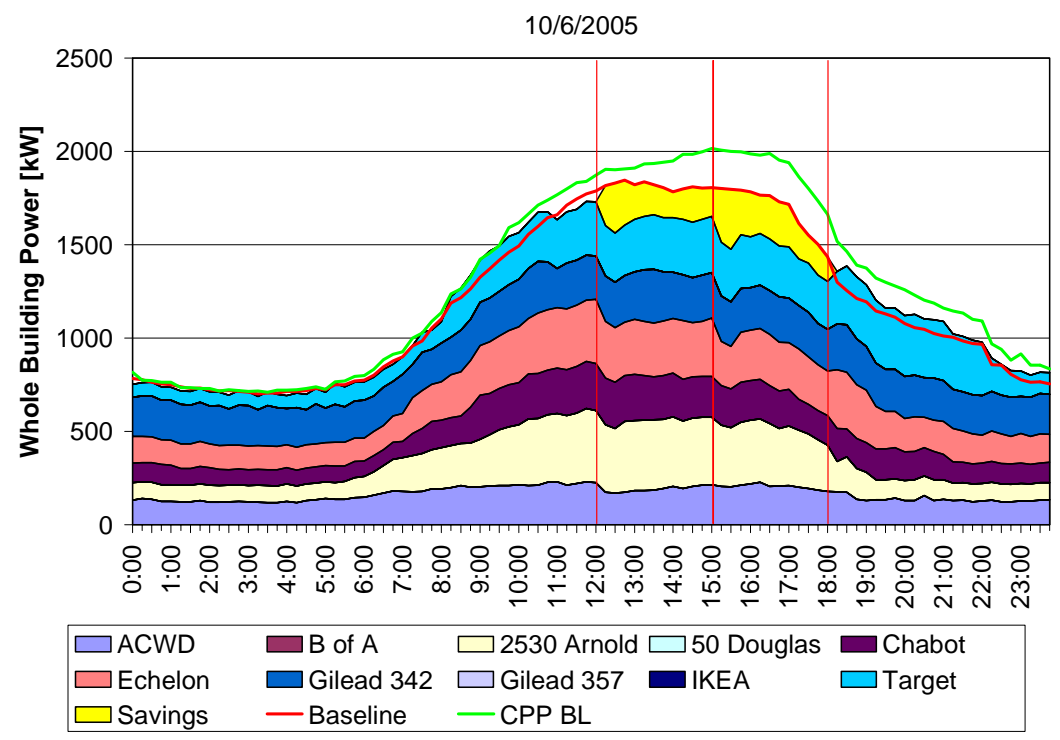

Figure 4-4: Aggregated Demand Saving, October $6^{\text {th }}$ 
Table 4-5 shows the average and maximum demand saving and electricity consumption results for each 3-hour period on October $6^{\text {th }}$. The maximum aggregated demand savings was $348 \mathrm{~kW}$ ( $19 \%$ of whole building power, $\left.0.73 \mathrm{~W} / \mathrm{ft}^{2}\right)$.

Table 4-5: Average Power Saving by Price Period, October $6^{\text {th }}$

\begin{tabular}{|c|c|c|c|c|c|c|c|c|c|}
\hline \multirow{2}{*}{ Unit } & \multirow{2}{*}{ Site Name } & \multicolumn{2}{|c|}{ Average } & \multicolumn{2}{|l|}{ Max } & \multirow{2}{*}{ Unit } & \multicolumn{3}{|c|}{ Consumption } \\
\hline & & $\overline{\text { Moderate } 1}$ & High & Moderate $\mathbf{F}$ & High & & Moderate & High & Total \\
\hline \multirow{6}{*}{$\begin{array}{c}\text { Shed } \\
\text { kW }\end{array}$} & ACWD & 55 & 28 & 74 & 47 & \multirow{6}{*}{$\begin{array}{l}\text { Shed } \\
\text { kWh }\end{array}$} & 165 & 83 & 248 \\
\hline & Chabot & 2 & 23 & 24 & 36 & & 7 & 69 & 75 \\
\hline & 2530 Arnold & 22 & 34 & 44 & 63 & & 65 & 102 & 167 \\
\hline & Echelon & 60 & 89 & 72 & 132 & & 181 & 268 & 449 \\
\hline & Gilead 342 & 24 & 21 & 45 & 32 & & 72 & 62 & 135 \\
\hline & Target & 22 & 24 & 60 & 39 & & 67 & 73 & 140 \\
\hline \multicolumn{2}{|c|}{ Total: $\Sigma(\Delta \mathrm{P})$} & 186 & 219 & 319 & 348 & & 557 & 657 & 1214 \\
\hline \multirow{6}{*}{$\begin{array}{c}\text { WBP } \\
\%\end{array}$} & ACWD & $22 \%$ & $12 \%$ & $31 \%$ & $19 \%$ & \multirow{6}{*}{$\begin{array}{c}\text { WBP } \\
\%\end{array}$} & $22 \%$ & $12 \%$ & $17 \%$ \\
\hline & Chabot & $1 \%$ & $10 \%$ & $10 \%$ & $15 \%$ & & $1 \%$ & $11 \%$ & $6 \%$ \\
\hline & 2530 Arnold & $6 \%$ & $9 \%$ & $11 \%$ & $17 \%$ & & $6 \%$ & $10 \%$ & $8 \%$ \\
\hline & Echelon & $17 \%$ & $26 \%$ & $20 \%$ & $37 \%$ & & $17 \%$ & $26 \%$ & $21 \%$ \\
\hline & Gilead 342 & $9 \%$ & $8 \%$ & $16 \%$ & $12 \%$ & & $9 \%$ & $8 \%$ & $8 \%$ \\
\hline & Target & $7 \%$ & $8 \%$ & $18 \%$ & $13 \%$ & & $7 \%$ & $8 \%$ & $8 \%$ \\
\hline \multicolumn{2}{|c|}{ Total: $\Sigma(\Delta \mathrm{P}) / \Sigma(\mathrm{BP})$} & $10 \%$ & $13 \%$ & $17 \%$ & $19 \%$ & & $10 \%$ & $13 \%$ & $11 \%$ \\
\hline \multicolumn{2}{|c|}{ Average: $\Sigma(\Delta \mathrm{P} / \mathrm{BP}) / \mathrm{N}$} & $10 \%$ & $12 \%$ & $18 \%$ & $19 \%$ & & $10 \%$ & $12 \%$ & $11 \%$ \\
\hline \multirow{6}{*}{$\mathbf{W} / \mathbf{f t}^{2}$} & ACWD & 1.25 & 0.63 & 1.69 & 1.06 & \multirow{6}{*}{$\mid \mathbf{W h} / \mathbf{f t}^{2}$} & 3.76 & 1.89 & $\overline{5.65}$ \\
\hline & Chabot & 0.03 & 0.27 & 0.28 & 0.42 & & 0.08 & 0.80 & 0.88 \\
\hline & 2530 Arnold & 0.17 & 0.26 & 0.33 & 0.48 & & 0.50 & 0.78 & 1.27 \\
\hline & Echelon & 0.81 & 1.19 & 0.96 & 1.76 & & 2.42 & 3.58 & 5.99 \\
\hline & Gilead 342 & 0.75 & 0.65 & 1.40 & 0.98 & & 2.25 & 1.95 & 4.20 \\
\hline & Target & 0.17 & 0.19 & 0.46 & 0.30 & & 0.51 & 0.56 & 1.08 \\
\hline \multicolumn{2}{|c|}{ Total: $\Sigma(\Delta \mathrm{P}) / \Sigma(\mathrm{A})$} & 0.37 & 0.44 & 0.64 & 0.70 & & 1.12 & 1.32 & $\overline{2.44}$ \\
\hline \multicolumn{2}{|c|}{ Average: $\Sigma(\Delta P / A) / N$} & 0.53 & 0.53 & 0.85 & 0.83 & & 1.59 & 1.59 & 3.18 \\
\hline
\end{tabular}




\section{Mock CPP Event on October $13^{\text {th }}$}

The October $13^{\text {th }}$ average OAT was $84^{\circ} \mathrm{F}$. Figure $4-5$ shows the aggregated demand profile of the nine successful sites.

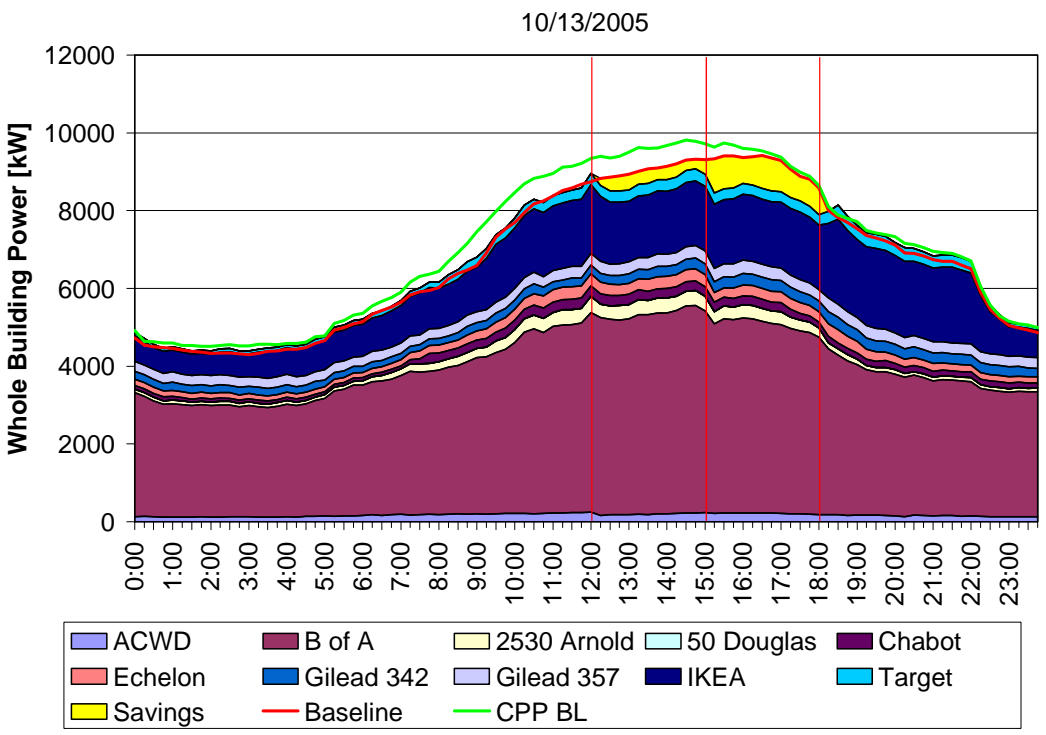

Figure 4-5: Aggregated Demand Saving, October $13^{\text {th }}$ 
Table 4-6 shows average and maximum demand saving result on October $6^{\text {th }}$ event. The maximum aggregated demand saving was $1108 \mathrm{~kW}(12 \%$ of whole building power, 0.78 $\left.\mathrm{W} / \mathrm{ft}^{2}\right)$.

Table 4-6: Average Power Saving by Price Period, October $13^{\text {th }}$

\begin{tabular}{|c|c|c|c|c|c|c|c|c|c|}
\hline \multirow{2}{*}{ Unit } & \multirow{2}{*}{ Site Name } & \multirow{2}{*}{\multicolumn{2}{|c|}{\begin{tabular}{|c|} 
Average \\
Moderate High \\
\end{tabular}}} & \multirow{2}{*}{\multicolumn{2}{|c|}{\begin{tabular}{|c|} 
Max \\
Moderate High \\
\end{tabular}}} & \multirow{2}{*}{ Unit } & \multicolumn{3}{|c|}{ Consumption } \\
\hline & & & & & & & Moderate & High & Total \\
\hline \multirow{9}{*}{$\begin{array}{c}\text { Shed } \\
\text { kW }\end{array}$} & $\overline{A C W D}$ & 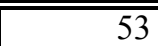 & & $\overline{773}$ & & \multirow{9}{*}{$\begin{array}{l}\text { Shed } \\
\text { kWh }\end{array}$} & 158 & 197 & 355 \\
\hline & $B$ of $A$ & -89 & 111 & -30 & 219 & & -266 & 334 & 68 \\
\hline & Chabot & -2 & 33 & 20 & 42 & & -6 & 98 & 91 \\
\hline & 2530 Arnold & 22 & 47 & 60 & 89 & & 66 & 141 & 207 \\
\hline & Echelon & 35 & 83 & 49 & 117 & & 106 & 248 & 354 \\
\hline & Gilead 342 & 32 & 34 & 55 & 55 & & 97 & 102 & 198 \\
\hline & Gilead 357 & 12 & 68 & 24 & 119 & & 37 & 205 & 241 \\
\hline & IKEA & 253 & 268 & 296 & 321 & & 759 & 804 & 1562 \\
\hline & Target & 12 & 55 & 20 & 64 & & 36 & 166 & 203 \\
\hline \multicolumn{2}{|c|}{ Total: $\Sigma(\Delta \mathrm{P})$} & 329 & 765 & 567 & 1108 & & 986 & 2294 & 3280 \\
\hline \multirow{9}{*}{$\begin{array}{c}\text { WBP } \\
\%\end{array}$} & $\overline{A C W D}$ & $21 \%$ & $24 \%$ & $31 \%$ & $29 \%$ & \multirow{9}{*}{$\begin{array}{c}\text { WBP } \\
\%\end{array}$} & $21 \%$ & $24 \%$ & $23 \%$ \\
\hline & $B$ of $A$ & $-2 \%$ & $2 \%$ & $-1 \%$ & $4 \%$ & & $-2 \%$ & $2 \%$ & $0 \%$ \\
\hline & Chabot & $-1 \%$ & $13 \%$ & $8 \%$ & $19 \%$ & & $-1 \%$ & $13 \%$ & $6 \%$ \\
\hline & 2530 Arnold & $6 \%$ & $13 \%$ & $15 \%$ & $22 \%$ & & $6 \%$ & $13 \%$ & $9 \%$ \\
\hline & Echelon & $11 \%$ & $24 \%$ & $15 \%$ & $33 \%$ & & $11 \%$ & $24 \%$ & $17 \%$ \\
\hline & Gilead 342 & $11 \%$ & $10 \%$ & $19 \%$ & $17 \%$ & & $11 \%$ & $11 \%$ & $11 \%$ \\
\hline & Gilead 357 & $4 \%$ & $17 \%$ & $7 \%$ & $26 \%$ & & $4 \%$ & $17 \%$ & $11 \%$ \\
\hline & IKEA & $13 \%$ & $14 \%$ & $16 \%$ & $16 \%$ & & $13 \%$ & $14 \%$ & $14 \%$ \\
\hline & Target & $4 \%$ & $17 \%$ & $7 \%$ & $19 \%$ & & $4 \%$ & $17 \%$ & $11 \%$ \\
\hline \multicolumn{2}{|c|}{ Total: $\Sigma(\Delta \mathrm{P}) / \Sigma(\mathrm{BP})$} & $4 \%$ & $8 \%$ & $6 \%$ & $12 \%$ & & $4 \%$ & $8 \%$ & $6 \%$ \\
\hline \multicolumn{2}{|c|}{ Average: $\Sigma(\Delta \mathrm{P} / \mathrm{BP}) / \mathrm{N}$} & $7 \%$ & $15 \%$ & $13 \%$ & $20 \%$ & & $7 \%$ & $15 \%$ & $11 \%$ \\
\hline \multirow{9}{*}{$\mathbf{W} / \mathbf{f t}^{2}$} & ACWD & 1.20 & 1.49 & 1.66 & 1.89 & \multirow{9}{*}{$\mathbf{W h} / \mathbf{f t}^{2}$} & 3.59 & 4.47 & 8.07 \\
\hline & $B$ of $A$ & -0.14 & 0.18 & -0.05 & 0.35 & & -0.43 & 0.54 & 0.11 \\
\hline & Chabot & -0.02 & 0.38 & 0.23 & 0.49 & & -0.07 & 1.13 & 1.06 \\
\hline & 2530 Arnold & 0.17 & 0.36 & 0.46 & 0.68 & & 0.51 & 1.08 & 1.58 \\
\hline & Echelon & 0.47 & 1.10 & 0.65 & 1.56 & & 1.41 & 3.30 & 4.72 \\
\hline & Gilead 342 & 1.01 & 1.06 & 1.72 & 1.73 & & 3.02 & 3.17 & 6.20 \\
\hline & Gilead 357 & 0.37 & 2.07 & 0.72 & 3.60 & & 1.11 & 6.21 & 7.32 \\
\hline & IKEA & 0.84 & 0.89 & 0.99 & 1.07 & & 2.53 & 2.68 & 5.21 \\
\hline & Target & 0.09 & 0.43 & 0.16 & 0.49 & & 0.28 & 1.28 & 1.56 \\
\hline \multicolumn{2}{|c|}{ Total: $\Sigma(\Delta \mathrm{P}) / \Sigma(\mathrm{A})$} & 0.23 & 0.53 & 0.39 & 0.77 & & 0.68 & 1.59 & 2.27 \\
\hline \multicolumn{2}{|c|}{ Average: $\Sigma(\Delta \mathrm{P} / \mathrm{A}) / \mathrm{N}$} & 0.44 & 0.88 & 0.73 & 1.32 & & 1.33 & 2.65 & 3.98 \\
\hline
\end{tabular}




\section{Mock CPP Event on October $25^{\text {th }}$}

The October $25^{\text {th }}$ average OAT was $66^{\circ} \mathrm{F}$. Figure 4-6 shows the aggregated demand profile for the nine successful sites.

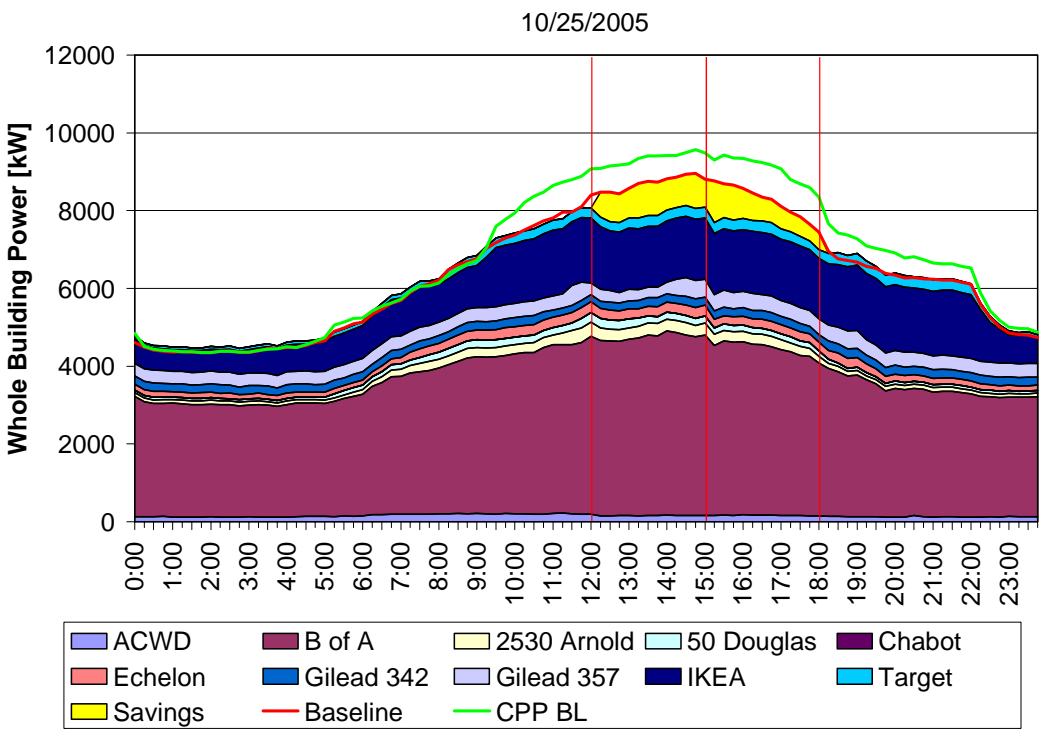

Figure 4-6: Aggregated Demand Saving, October $25^{\text {th }}$ 
Table 4-7 shows the average and maximum demand savings and electricity consumption results for each 3-hour period on October $25^{\text {th }}$ event. The maximum aggregated demand saving was $1134 \mathrm{~kW}$ (13\% of whole building power, $\left.0.79 \mathrm{~W} / \mathrm{ft}^{2}\right)$.

Table 4-7: Average Power Saving by Price Period, October $25^{\text {th }}$

\begin{tabular}{|c|c|c|c|c|c|c|c|c|c|}
\hline \multirow{2}{*}{ Unit } & \multirow{2}{*}{ Site Name } & \multicolumn{2}{|c|}{\begin{tabular}{|l|} 
Average \\
\end{tabular}} & \multicolumn{2}{|l|}{ Max } & \multirow{2}{*}{ Unit } & \multicolumn{3}{|c|}{ Consumption } \\
\hline & & Moderate & High & Moderate & High & & Moderate & High & Total \\
\hline \multirow{9}{*}{$\begin{array}{c}\text { Shed } \\
\text { kW }\end{array}$} & $\overline{A C W D}$ & $\overline{669}$ & 57 & $\overline{777}$ & & \multirow{9}{*}{$\begin{array}{l}\text { Shed } \\
\text { kWh }\end{array}$} & 207 & 170 & 377 \\
\hline & $B$ of $A$ & 279 & 291 & 461 & 552 & & 836 & 874 & 1710 \\
\hline & 2530 Arnold & 28 & 17 & 40 & 39 & & 84 & 51 & 135 \\
\hline & 50 Douglas & 41 & 42 & 75 & 78 & & 124 & 126 & 251 \\
\hline & Echelon & 33 & & 45 & 84 & & 98 & 180 & 278 \\
\hline & Gilead 342 & 60 & 53 & 80 & 70 & & 181 & 158 & 339 \\
\hline & Gilead 357 & 66 & -40 & 145 & -11 & & 198 & -119 & 79 \\
\hline & IKEA & 204 & 169 & 223 & 207 & & 613 & 508 & 1122 \\
\hline & Target & 15 & 16 & 33 & 49 & & 44 & 48 & 92 \\
\hline \multicolumn{2}{|c|}{ Total: $\Sigma(\Delta \mathrm{P})$} & 795 & 665 & 1179 & 1134 & & 2386 & 1996 & 4381 \\
\hline \multirow{9}{*}{$\begin{array}{c}\text { WBP } \\
\%\end{array}$} & $\overline{A C W D}$ & $30 \%$ & $26 \%$ & $35 \%$ & $30 \%$ & \multirow{9}{*}{$\begin{array}{c}\text { WBP } \\
\%\end{array}$} & $30 \%$ & $26 \%$ & $28 \%$ \\
\hline & B of $A$ & $6 \%$ & $6 \%$ & $9 \%$ & $11 \%$ & & $6 \%$ & & $6 \%$ \\
\hline & 2530 Arnold & $8 \%$ & $6 \%$ & $12 \%$ & $12 \%$ & & $8 \%$ & $6 \%$ & $8 \%$ \\
\hline & 50 Douglas & $17 \%$ & $20 \%$ & $30 \%$ & $32 \%$ & & $17 \%$ & $21 \%$ & $19 \%$ \\
\hline & Echelon & $11 \%$ & $21 \%$ & $16 \%$ & $28 \%$ & & $11 \%$ & $21 \%$ & $16 \%$ \\
\hline & Gilead 342 & $22 \%$ & $20 \%$ & $30 \%$ & $26 \%$ & & $22 \%$ & $20 \%$ & $21 \%$ \\
\hline & Gilead 357 & $16 \%$ & $-11 \%$ & $35 \%$ & $-3 \%$ & & $16 \%$ & $-11 \%$ & $3 \%$ \\
\hline & IKEA & $12 \%$ & $10 \%$ & $12 \%$ & $12 \%$ & & $12 \%$ & $10 \%$ & $11 \%$ \\
\hline & Target & $5 \%$ & $6 \%$ & $12 \%$ & $18 \%$ & & $5 \%$ & $6 \%$ & $5 \%$ \\
\hline \multicolumn{2}{|c|}{ Total: $\Sigma(\Delta \mathrm{P}) / \Sigma(\mathrm{BP})$} & $9 \%$ & $8 \%$ & $13 \%$ & $13 \%$ & & $9 \%$ & $8 \%$ & $8 \%$ \\
\hline \multicolumn{2}{|c|}{ Average: $\Sigma(\Delta \mathrm{P} / \mathrm{BP}) / \mathrm{N}$} & $14 \%$ & $11 \%$ & $21 \%$ & $18 \%$ & & $14 \%$ & $12 \%$ & $13 \%$ \\
\hline \multirow{9}{*}{$\mathbf{W} / \mathbf{f t}^{2}$} & ACWD & 1.57 & 1.29 & 1.76 & 1.50 & \multirow{9}{*}{$\mathbf{W h} / \mathbf{f t}^{2}$} & 4.70 & 3.86 & 8.56 \\
\hline & B of $A$ & 0.45 & 0.47 & 0.75 & 0.90 & & 1.36 & 1.42 & 2.78 \\
\hline & 2530 Arnold & 0.21 & 0.13 & 0.31 & 0.30 & & 0.64 & 0.39 & 1.03 \\
\hline & 50 Douglas & 0.46 & 0.47 & 0.83 & $0.87 \|$ & & 1.38 & 1.40 & 2.78 \\
\hline & Echelon & 0.43 & 0.80 & 0.60 & $1.11 \|$ & & 1.30 & 2.40 & 3.70 \\
\hline & Gilead 342 & 1.89 & 1.64 & 2.51 & $2.20 \|$ & & 5.66 & 4.93 & 10.58 \\
\hline & Gilead 357 & 2.00 & -1.20 & 4.38 & -0.34 & & 6.00 & -3.61 & 2.40 \\
\hline & IKEA & 0.68 & 0.56 & 0.74 & 0.69 & & 2.04 & 1.69 & 3.74 \\
\hline & Target & 0.11 & 0.12 & 0.25 & 0.38 & & 0.34 & 0.37 & 0.70 \\
\hline \multicolumn{2}{|c|}{ Total: $\Sigma(\Delta \mathrm{P}) / \Sigma(\mathrm{A})$} & 0.55 & 0.46 & 0.81 & 0.78 & & 1.64 & 1.38 & 3.02 \\
\hline \multicolumn{2}{|c|}{ Average: $\Sigma(\Delta \mathrm{P} / \mathrm{A}) / \mathrm{N}$} & 0.87 & 0.48 & 1.35 & 0.85 & & 2.60 & 1.43 & 4.03 \\
\hline
\end{tabular}




\section{Additional Tests for CLIR Box Demonstration}

Due to their internal network issues, Irvington High School (FUSD) and Oracle were unable to participate in the Auto-CPP events during the CPP program period. Both sites didn't have Internet gateways and their network security wouldn't allow Internet relay communication. The CLIR Box was installed at both of these sites at the end of October 2005. The first CLIR Box was installed at Oracle on October $27^{\text {th }}$. Although LBNL staff and an Akuacom engineer were there for installation and troubleshooting, the Oracle facility manager was able to install the box by himself. However, the CLIR Box required additional configurations for the proxy server, and the Akuacom engineer took a few hours to determine the correct configuration. The same proxy server issue occurred at Irvington. This proxy server configuration will be programmed into future CLIR Box.

The additional mock CPP events were conducted to test the CLIR Box communication and the Irvington and Oracle sites' demand response control. The Oracle event was issued for November $10^{\text {th }}$. Oracle successfully curtailed a maximum of $65 \mathrm{~kW}(0.22$ $\mathrm{W} / \mathrm{ft}^{2}, 14 \%$ of WBP) with only minor communication issues. For Irvington's November $15^{\text {th }}$ test, the price signal communication test was successful, but the controls failed to change the control state due to unknown reasons. Appendix B further discusses the details of these events and their results.

\subsection{Overall Results}

As the number of sites participating in each 2005 Auto-CPP event was not consistent, it is difficult to compare demand saving $\mathrm{kW}$ values between the events. Table 4-8 shows the baseline peak demand, the maximum 15-minute demand savings for each Auto-CPP test and the non-coincident maximum demand savings. If all twelve sites were able to achieve their maximum demand savings simultaneously, a total of approximately $2 \mathrm{MW}$ of demand response would be available from these twelve sites that represent about two million $\mathrm{ft}^{2}$ of conditioned floor area. Using the summation of the average demand savings for each of the twelve sites results in an average demand saving of approximately $1 \mathrm{MW}$. These results indicate 1 to $2 \mathrm{MW}$ of demand saving achievement can be expected for two million $\mathrm{ft}^{2}$ of buildings ( 0.5 to $1.0 \mathrm{~W} / \mathrm{ft}^{2}$ of demand saving).

The data in Table 4-8 is shown in absolute power $(\mathrm{kW})$ to show the size of building demand savings that could be available from this type of a commercial building sample. Results could also be shown in power density $\left(\mathrm{W} / \mathrm{ft}^{2}\right)$, but the absolute demand saving $(\mathrm{kW})$ is useful for future demand response resource planning. 
Table 4-8: Maximum Demand saving by Site and Non-Coincident Aggregated Saving

\begin{tabular}{|c|c|c|c|c|c|c|c|c|c|c|}
\hline & & \begin{tabular}{|l|} 
Aug-08 \\
\end{tabular} & Sep-22 & Sep-29 & Oct-06 & Oct-13 & Oct-25 & Nov-10 & 2004 & Max \\
\hline ACWD & $\begin{array}{l}\text { Baseline Peak kW } \\
\text { Max Shed kW }\end{array}$ & & & $\begin{array}{l}330 \\
101\end{array}$ & $\begin{array}{r}253 \\
74\end{array}$ & $\begin{array}{r}290 \\
83\end{array}$ & $\begin{array}{r}238 \\
77\end{array}$ & & & $\begin{array}{l}330 \\
101\end{array}$ \\
\hline$\overline{B \text { of } A}$ & $\begin{array}{l}\text { Baseline Peak kW } \\
\text { Max Shed kW }\end{array}$ & & & $\begin{array}{r}5311 \\
291\end{array}$ & & $\begin{array}{r}5163 \\
219\end{array}$ & $\begin{array}{r}5053 \\
552\end{array}$ & & & $\begin{array}{r}5053 \\
552\end{array}$ \\
\hline Chabot & $\begin{array}{l}\text { Baseline Peak kW } \\
\text { Max Shed kW }\end{array}$ & & $\begin{array}{r}225 \\
19\end{array}$ & $\begin{array}{r}308 \\
88\end{array}$ & $\begin{array}{r}244 \\
36\end{array}$ & $\begin{array}{r}270 \\
42 \\
\end{array}$ & & & & $\begin{array}{r}308 \\
88\end{array}$ \\
\hline 2530 Arnold & $\begin{array}{l}\text { Baseline Peak kW } \\
\text { Max Shed kW }\end{array}$ & $\begin{array}{l}505 \\
176 \\
\end{array}$ & $\begin{array}{l}419 \\
119\end{array}$ & $\begin{array}{r}431 \\
90\end{array}$ & $\begin{array}{r}404 \\
63 \\
\end{array}$ & $\begin{array}{r}406 \\
89\end{array}$ & $\begin{array}{r}345 \\
40\end{array}$ & & & $\begin{array}{l}505 \\
176\end{array}$ \\
\hline 50 Douglas & $\begin{array}{l}\text { Baseline Peak kW } \\
\text { Max Shed kW }\end{array}$ & $\begin{array}{r}381 \\
95 \\
\end{array}$ & & & & & $\begin{array}{r}259 \\
78 \\
\end{array}$ & & & $\begin{array}{r}381 \\
95 \\
\end{array}$ \\
\hline \begin{tabular}{|l} 
Echelon \\
\end{tabular} & $\begin{array}{l}\text { Baseline Peak kW } \\
\text { Max Shed kW }\end{array}$ & & $\begin{array}{l}334 \\
115\end{array}$ & $\begin{array}{l}403 \\
143\end{array}$ & $\begin{array}{l}363 \\
132\end{array}$ & $\begin{array}{l}359 \\
117\end{array}$ & $\begin{array}{r}304 \\
84\end{array}$ & & & $\begin{array}{l}403 \\
143\end{array}$ \\
\hline Gilead 342 & $\begin{array}{l}\text { Baseline Peak kW } \\
\text { Max Shed kW }\end{array}$ & & $\begin{array}{r}288 \\
94\end{array}$ & $\begin{array}{r}384 \\
75\end{array}$ & $\begin{array}{r}289 \\
45\end{array}$ & $\begin{array}{r}340 \\
55\end{array}$ & $\begin{array}{r}278 \\
80\end{array}$ & & & $\begin{array}{r}288 \\
94\end{array}$ \\
\hline Gilead 357 & $\begin{array}{l}\text { Baseline Peak kW } \\
\text { Max Shed kW }\end{array}$ & & & $\begin{array}{l}607 \\
150\end{array}$ & & $\begin{array}{l}455 \\
119\end{array}$ & $\begin{array}{l}443 \\
145\end{array}$ & & & $\begin{array}{l}607 \\
150\end{array}$ \\
\hline IKEA & $\begin{array}{l}\text { Baseline Peak kW } \\
\text { Max Shed kW }\end{array}$ & & & & & $\begin{array}{r}1982 \\
321\end{array}$ & $\begin{array}{r}1803 \\
223\end{array}$ & & & $\begin{array}{r}1982 \\
321\end{array}$ \\
\hline Oracle & $\begin{array}{l}\text { Baseline Peak kW } \\
\text { Max Shed kW }\end{array}$ & & & & & & & $\begin{array}{r}507 \\
65 \\
\end{array}$ & & $\begin{array}{r}507 \\
65 \\
\end{array}$ \\
\hline Target & $\begin{array}{l}\text { Baseline Peak kW } \\
\text { Max Shed kW }\end{array}$ & & $\begin{array}{r}314 \\
52\end{array}$ & $\begin{array}{r}364 \\
53\end{array}$ & $\begin{array}{r}328 \\
60\end{array}$ & $\begin{array}{r}341 \\
64\end{array}$ & $\begin{array}{r}296 \\
49\end{array}$ & & & $\begin{array}{r}341 \\
64\end{array}$ \\
\hline USPS* & $\begin{array}{l}\text { Baseline Peak kW } \\
\text { Max Shed kW }\end{array}$ & & & & & & & & $\begin{array}{r}1483 \\
333 \\
\end{array}$ & $\begin{array}{r}1483 \\
333\end{array}$ \\
\hline Total & $\begin{array}{l}\text { Baseline Peak kW } \\
\text { Max Shed kW }\end{array}$ & $\begin{array}{l}886 \\
272\end{array}$ & $\begin{array}{r}1579 \\
399\end{array}$ & $\begin{array}{r}8138 \\
992\end{array}$ & $\begin{array}{r}1881 \\
410 \\
\end{array}$ & $\begin{array}{l}9608 \\
1108\end{array}$ & $\begin{array}{l}9020 \\
1329\end{array}$ & $\begin{array}{r}507 \\
65 \\
\end{array}$ & $\begin{array}{r}1483 \\
333 \\
\end{array}$ & $\begin{array}{r}12189 \\
2182\end{array}$ \\
\hline
\end{tabular}

* 2004 data (Oct-13) is used for USPS because USPS failed to conduct demand shed in 2005.

\subsection{Incremental Cost for Materials and Installation}

The Auto-CPP sites connected their EMCS to the DR Automation Server using one of three options made available by LBNL: 1) Internet gateway; 2) Internet Relay; and 3) CLIR box. Internet gateway and relays were available from the beginning of the project. The CLIR Box was designed during the project once the need for a secure connectivity option became apparent. This option was available in October 2005. Table 4-9 summarizes hardware and typical installation costs for the three options. The Internet Relay is the least expensive, followed by the CLIR box. The Internet gateway is the most cost and labor-intensive option.

Table 4-9: Hardware Cost of Each Connectivity Option for Auto-DR

\begin{tabular}{|l|c|c|}
\hline Connectivity Option & Hardware Cost & Installation Cost \\
\hline Internet Gateway & $\$ 2,000^{*}$ & $\$ 15,000^{*}$ \\
\hline Internet Relay & $\$ 200$ & $\$ 2,000$ \\
\hline CLIR Box & $\$ 800$ & $\$ 2,000$ \\
\hline
\end{tabular}

* Cost of gateway widely varies by its capabilities.

Table 4-10 summarizes the range of costs reported for EMCS programming and AutoCPP communication system installation and configuration. Each site's EMCS had to be programmed to curtail loads when the price signal was detected. EMCS data trends were also requested where available. Auto-CPP communication system installation and 
configuration included polling client software programming, and relay or other hardware installation depending on the connectivity option each site used. The costs associated with various connectivity options are described below.

Table 4-10: Summary of Cost for Auto-CPP Implementation

\begin{tabular}{|c|c|c|c|c|c|c|c|c|c|}
\hline & \multicolumn{5}{|c|}{ Cost Breakdown } & \multirow[b]{2}{*}{$\begin{array}{l}\text { Total } \\
\text { Cost } \\
\end{array}$} & \multirow[b]{2}{*}{ Cost $\$ / \mathbf{f t}^{2}$} & \multirow[b]{2}{*}{\begin{tabular}{|l|} 
Potential \\
incentive
\end{tabular}} & \multirow[b]{2}{*}{$\begin{array}{c}\text { Max } \\
\text { shed } k W \\
\end{array}$} \\
\hline Site Name & $\begin{array}{c}\text { EMCS } \\
\text { Prog. }\end{array}$ & \begin{tabular}{|l|} 
EMCS \\
Trend
\end{tabular} & \begin{tabular}{|c|}
$\begin{array}{c}\text { Software } \\
\text { Prog. }\end{array}$ \\
\end{tabular} & \begin{tabular}{|c|} 
Relay \\
Installation
\end{tabular} & Other & & & & \\
\hline ACWD & $\$ 44,875$ & Included & - & $\$ 3,750$ & $\$ 4,199(* 1)$ & $\$ 12,824$ & 0.25 & $\$ \$ \$ 5,100$ & 101 \\
\hline B of $A$ & $\$ 720$ & $\$ 240$ & - & $\$ 260$ & $\$ 420(* 1)$ & $\$ 1,640$ & 0.002 & $\$ 27,600$ & 552 \\
\hline Chabot & $\$ 2,760$ & Included & - & $\$ 1,750$ & - & $\$ 4,510$ & 0.05 & $\$ 4,400$ & 88 \\
\hline 50 Douglas & - & $\$ 1,000$ & - & - & $\$ 1,000(* 1)$ & $\$ 2,000$ & 0.02 & $\$ 8,800$ & 176 \\
\hline 2530 Arnold & - & $\$ 1,000$ & - & - & $\$ 1,000(* 1)$ & $\$ 2,000$ & 0.02 & $\$ 4,800$ & 95 \\
\hline Echelon & $\$ 1,920$ & - & $\$ 1,500$ & - & $\$ 200(* 1)$ & $\$ 3,620$ & 0.05 & $\$ 7,200$ & 143 \\
\hline Irvington & $\$ 2,000$ & Included & - & - & - & $\$ 2,000$ & & N/A & $\mathrm{N} / \mathrm{A}$ \\
\hline Gilead (3 bldgs) & $\$ 2,000$ & $\$ 2,500$ & - & $\$ 1,000$ & $\$ 2,000(* 2)$ & $\$ 7,500$ & 0.05 & $\$ 12,200$ & 244 \\
\hline IKEA & $\$ 2,280$ & $\$ 190$ & - & $\$ 380$ & $\$ 2,200(* 3)$ & $\$ 5,050$ & 0.02 & $\$ 16,000$ & 321 \\
\hline LBNL OSF & $\$ 2,000$ & Included & - & $\$ 2,000$ & $\$ 1,000(* 4)$ & $\$ 5,000$ & 0.07 & $\mathrm{~N} / \mathrm{A}$ & $\mathrm{N} / \mathrm{A}$ \\
\hline Oracle & $\$ 150$ & - & - & $\$ 225$ & - & $\$ 375$ & 0.00 & $\$ 5,000$ & 100 \\
\hline Target & $\$ 312$ & Included & $\$ 3,000$ & - & - & $\$ 3,312$ & 0.03 & $\$ 9,900$ & 198 \\
\hline USPS & - & - & $\$ 10,000$ & - & $\$ 2,000(* 3)$ & $\$ 12,000$ & 0.03 & $\$ 16,700$ & 333 \\
\hline
\end{tabular}

(*1): Additional project management cost of site personnel

$(* 2)$ : DR user interface development

$(* 3)$ : Additional project management cost of control contractor

(*4): AHU electric submetering

\section{Internet Gateway}

Site-specific software development is required for the Internet gateway option. Typically, participants with on-site programming capabilities utilized this option. The nature of the code provided by LBNL made it easy for the programmers to integrate their site's code and LBNL offered help to those sites having problems. The cost of software development for Echelon, Target and USPS were $\$ 1,500, \$ 3,000$ and $\$ 10,000$, respectively. All the sites that chose the Internet gateway option already had a gateway in place and in use. There were no associated hardware purchase costs for these sites.

\section{Internet Relay}

The Internet relay is a simple device that provides three dry contacts that connect to the EMCS. Most sites had their control company install and configure their device. Installation of the relay itself was not a difficult task, but installation costs were incurred if the site hired a control company to install their relay.

\section{CLIR Box}

The CLIR box is preconfigured and eliminates the cost of network configuration. Although LBNL staff and Akuacom engineers were on site for installation and troubleshooting of the first two CLIR boxes, any on-site facility staff should be able to complete the installation quickly without any technical support. Since the CLIR Box is a combination of the polling client and the Internet relay, the relay installation cost still applies. 
Some costs reported are the actual costs budgeted specifically for the Auto-CPP program participation. However, many sites used their in-house labor to install and configure their equipment and had their control vendors do additional EMCS programming work within their existing contracts. B of A, Contra Costa, and Echelon did the Auto-CPP setup without allocating a specific budget - their costs listed in Table 4-10 were estimated based on the time spent and their hourly labor rate.

The site-specific costs associated with automated CPP implementation were the highest at ACWD and lowest at B of A. The cost data for these sites are considered outliers since the ACWD is much higher than other sites with an Internet relay and B of A had participated in similar studies with LBNL in previous years and had installed their relay earlier.

The Technical Assistance Incentive Program offered by PG\&E provides a one-time cash rebate of $\$ 50$ per potential demand saving $\mathrm{kW}$ for professional technical assistance that enhances demand response ability for CPP participant sites. Although none of the sites applied for this incentive during the 2005 test period, the potential amount of incentives are also listed in Table 4-10. The comparison between the total cost and the incentive amount indicates that most of the Auto-CPP participants would recover their initial installation/configuration costs.

\subsection{Results of Sub Analyses}

\section{Pre-cooling and Occupant Surveys}

The pre-cooling sub study found that pre-cooling demand response strategies worked well in the light office building and were able to reduce their cooling load significantly ( $\sim 35 \%$ on cool days, $\sim 25 \%$ on hot days) - though the sites noticed reductions in their comfort levels. Use of the well-controlled exponential temperature set up strategy during the demand response period can discharge thermal mass smoothly and with no rebound.

Night pre-cooling had noticeable effects on the second day cooling load in heavy mass buildings - reducing both HAVC peak demand and energy consumption. Figure 4-7 shows the Chabot chiller power usage for the baseline and different pre-cooling strategies. The pre-cooling and exponential temperature set up in the afternoon reduced the demand most significantly. 


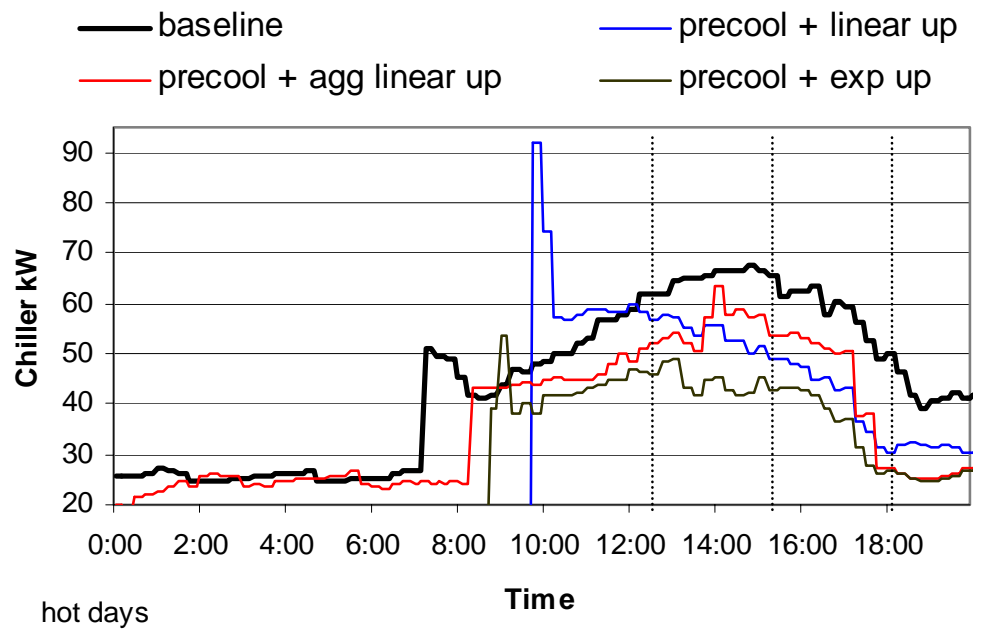

Figure 4-7: Chabot: Whole Building Power Demand of Pre-cooling Tests

Figure 4-8 shows the Chabot daily HVAC energy consumption for the pre-cooling days. HVAC energy consumption was reduced significantly. The most successfully strategies, pre-cooling plus exponential set up in the afternoon, can reduce the HVAC energy consumption by up to $40 \%$.

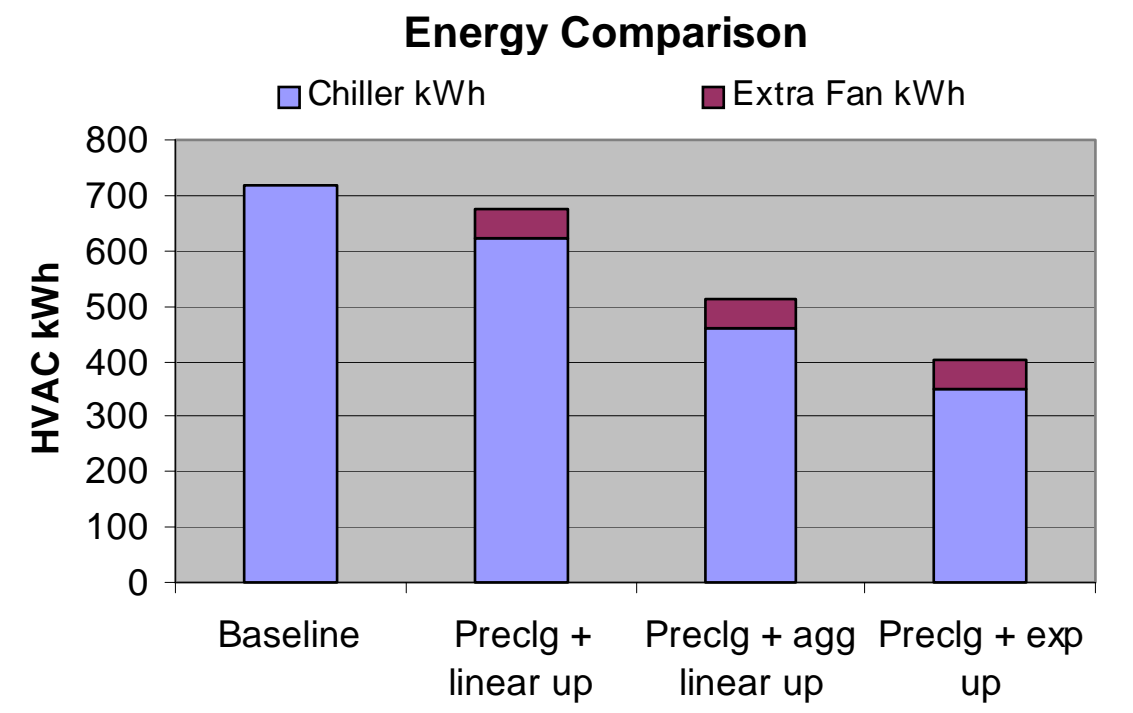

Figure 4-8: Chabot: Daily HVAC Energy Consumption of Pre-cooling Test Days

The conclusion of the pre-cooling work to date is that pre-cooling has the potential to improve the demand responsiveness of commercial buildings while maintaining acceptable comfort conditions. Further work is required to quantify and demonstrate the effectiveness of pre-cooling in different building types and climates and to develop screening tools that can be used to select suitable buildings and customers, identify the most appropriate pre-cooling strategies and estimate the benefits to the customer and the utility. 


\section{Indoor Environmental Quality Study in Retail Store}

Two experiments during the mock CPP events on October $6^{\text {th }}$ and October $25^{\text {th }}$ were conducted to evaluate the impact of ventilation-based demand response on the indoor environment of a large retail store. Measurement of the ventilation rate in the sales area was performed by a tracer gas decay technique. In Experiment 1, valid samples were obtained only from RTUs 11 and 13 due to a mechanical problem with the manifold system on RTU 15. In addition, sampling on this date did not begin until 11:00, with six samples collected from each of the two RTUs in the Pre-DR (morning)period between 11:00 and 12:00. An additional six samples were collected from each RTU during the DR period from 12:00 to 14:00. In Experiment 2, samples were colleted at approximately 20 minute intervals between 10:00 and 14:00 from all three RTUs, resulting in a total of 36 samples.

Air samples for the analysis of VOCs and low molecular weight aldehydes were also collected. Samples were collected from the return air ducts of RTUs 11, 13 and 15 at the end of the Pre-DR period from 11:00 to 12:00 and near the end of the DR period from 16:00 to 17:00. These time periods were selected so that comparisons could be made assuming quasi steady-state conditions. As noted above, the samples obtained from RTU 15 in Experiment 1 were compromised by a mechanical problem and were discarded. Additional sets of air samples for VOCs and aldehydes were collected during a preliminary walk-through survey conducted in the mid morning of July $29^{\text {th }}, 2005$.

This study provided data on the concentrations of a number of VOC air contaminants in a large general merchandise discount store. Such data previously were unavailable. For some compounds, substantial spatial variability (i.e., a factor of two or more) was observed among concentrations measured at several rooftop air-handling units. However, the results generally were consistent across all three sampling events, which also included an integrated sample obtained while walking through the aisles of the various sales departments. The measured concentrations generally were low, in comparison with concentrations in other buildings and in comparison with conservative exposure guidelines. In addition, ventilation rates were measured. These measurements indicated that, in non-demand-response mode, the store was operating near, but somewhat below, current ASHRAE ventilation guidelines for retail environments.

Information obtained on the effects of peak electrical demand response implemented by deactivating a fraction of the rooftop air-handling units was limited to a single simulated event. When five of the twelve air-handling units in the sales area were turned off, the ventilation rate measured in the sales area decreased by about $30 \%$. Concentrations of a number of air contaminants measured near the end of the demand response period increased as expected in response to the ventilation rate change. The magnitudes of the increases varied substantially likely as the result of a number of factors including changes in contaminant emission rates from primary sources both dependent and independent of the ventilation rate change, and secondary effects related to ventilation such as higher sorption of contaminants to surfaces at higher air concentrations. Typical increases in concentrations were somewhat higher than the corresponding decrease in the ventilation rate. 
Further study is needed to characterize ventilation rates and the concentrations of air contaminants across various retail environments. It would be prudent to obtain such information before broadly recommending electrical demand response for the retail sector through measures that decrease ventilation rates. Additionally, surveys of air contaminant concentrations can be conducted as a means of qualifying specific buildings for such demand response programs. 


\section{Discussion}

The Auto-CPP tests in 2005 have demonstrated the technical feasibility of fully automated DR. This section provides a brief discussion of the key issues. While there are considerable challenges in Auto-DR in general and Auto-CPP specifically, the research demonstrates that this can be done with reasonable levels of effort with today's technology. There are three key barriers in automating demand response. These barriers include 1) recruitment, 2) EMCS and control capabilities and strategies, and 3) installation and configuration of Auto-DR systems.

The barrier concerning recruitment is significant because the concept of modifying the building control strategies for short periods to modify the electric load shape is foreign to most building operators and energy managers. Facility staff need to understand many technical issues to support the notion of participating in DR program and to consider Auto-CPP. They need to understand the complex electricity pricing, the capabilities of their control systems, and the relationship between their existing electric load shape and their controls capabilities.

Most (all but one) of the buildings in this study used their EMCS as the basis of the DR control strategies. One lesson in this research is the need to improve knowledge of what strategies create good demand response that is reliable and maximizes the demand saving while minimizing any loss of service within the facility. Auto-DR is much easier to accomplish with newer control systems, especially those with Direct Digital Control systems that are able to control down to the building's thermal zones. In general, improvements in control technologies enhance DR capabilities by providing finer grain control and better information management. Future technologies such as dimmable ballasts and wireless controls show promise in providing more levels of dynamic response. The Auto-DR research will benefit from improved collaboration from the building commissioning industry as commissioning engineers improve knowledge and process to ensure controls work as intended.

The third barrier regarding installation and configuration of Auto-DR systems is likely to be less of a problem then the previous two barriers. Improvements in standardizing the Auto-DR configuration and systems integration suggest that the process can be streamlined. This research has begun to explore the financial and economic issues associated with Auto-DR and knowledge from a broad set of buildings is needed to better understand the effort to configure such facilities on a broader scale. 


\section{Related and Future Research}

This study, the third year of Auto-DR field tests, continues to show the potential for automated demand response systems. This section provides a brief overview of current plans and related work in this area.

- Automated DR Strategies Overview - LBNL is in the process of developing a review of the control strategies in the Auto-DR projects from all three years. This is an important piece of practical research to help characterize and evaluate the type of strategies that the facilities have developed and implemented. Such information is greatly needed by engineers, building operators, and energy managers to share their experience with DR strategies.

- Automated DR for 2006 - LBNL is continuing to work with CEC, PIER and the California utilities to plan another set of field tests. The plan for the PG\&E tests is to consider the research needed to launch a broader Auto-DR effort in 2007. LBNL and PG\&E are discussing the design of the field tests to understand the economics of Auto-DR and the issues with scaling up the participation.

- Advanced Controls for Energy Efficiency and DR - LBNL has written two research papers relating energy efficiency and DR (Kiliccote and Piette, 2006 and Kiliccote and Piette, 2005).

- DR Tools - PIER is developing an economic analysis tool to help large facilities evaluate the economics of DR.

- DR Database - PIER is developing a database of DR results from actual facilities to assist in understanding current DR capabilities with large electricity customers.

Further work is needed to further evaluate the DR strategies possible for a broader range of building systems, building types, and climatic conditions. Further research is also needed to determine the economics of such DR, evaluate reasonable scenarios for the frequency and duration of DR, and identify and evaluate possible occupant and tenant issues. 


\section{References}

Hotchi, Toshifumi, A.T. Hodgson and W.J. Fisk. 2006. Indoor Air Quality Impacts of a Peak Load Shedding Strategy for a Large Retail Building. LBNL Report 59293. January.

KEMA-Xenergy. 2003. Protocol Development for Demand Response Calculation Findings and Recommendations: Consultant Report). Energy Commission publication \# 400-02-017F.

Kiliccote, Sila and M.A. Piette. 2005. Advanced Control Technologies and Strategies Linking Demand Response and Energy Efficiency. Proceedings of the Fifth Annual International Conference on Enhanced Building Operations, Pittsburgh, PA. LBNL Report 58179. October.

Kiliccote S., Piette M.A. and Hansen D. 2006. Advanced Controls and Communications for Demand Response and Energy Efficiency in Commercial Buildings.

Proceedings of Second Carnegie Mellon Conference in Electric Power Systems: Monitoring, Sensing, Software and Its Valuation for the Changing Electric Power Industry, Pittsburgh, PA. LBNL Report 59337. January.

Pacific Gas and Electric. 2005. Demand Response Programs: Critical Peak Pricing. http://www.pge.com/biz/demand_response/critical_peak_pricing/index.html

Piette, Mary Ann, D. Watson, N. Motegi, Norman Bourassa and C. Shockman, "Findings from the 2004 Fully Automated Demand Response Tests in Large Facilities" September 2005. CEC-500-03-026. LBNL-58178. Available at http://drrc.lbl.gov/drrc-pubs 1.html

Piette, Mary Ann, O. Sezgen, D. Watson, N. Motegi, and C. Shockman, "Development and Evaluation of Fully Automated Demand Response in Large Facilities", January 2005. CEC-500-2005-013. LBNL-55085. Available at http://drrc.lbl.gov/drrc-pubs1.html

Quantum Consulting and Summit Blue Consulting. Working Group 2 Demand Response Program Evaluation - Program Year 2004. Final Report. December 2004.

State of California. 2000. Assembly Bill AB970: Electrical Energy: Thermal Powerplants: Permits. September 7, 2000.

State of California. 2001. Senate Bill SB5X: Sher, Chapter 7, 1st Extraordinary Session, Statutes of 2001. http://info.sen.ca.gov/pub/01-02/bill/sen/sb_00010050/sbx1_5_bill_20010412_chaptered.pdf.

Xu, Peng and Philip Haves, and Mary Ann Piette (LBNL), and James Braun (Purdue). 2004. Peak demand reduction from pre-cooling with zone temperature reset of HVAC in an office. Proceedings of 2004 ACEEE Summer Study on Energy Efficiency in Buildings. Pacific Grove, CA. LBNL-55800. 2004.

Xu, Peng and Philip Haves, MaryAnn Piette, Leah Zagreus. 2005. Demand shifting with Thermal Mass in Large Commercial Buildings (Audit, Field tests and 
Simulations). LBNL report to California Energy Commission. Berkeley, CA.: Lawrence Berkeley National Laboratory. 2001. LBNL/PUB-930.

$\mathrm{Xu}$, Peng and Philip Haves. 2005. Case Study of Demand Shifting With Thermal Mass in Two Large Commercial Buildings. ASHRAE Transactions. LBNL-58649.

Zagreus, Leah, Ed Arens and Carrie Brown. Occupant Thermal Comfort and Perceived Productivity in Three Office Buildings Participating in Auto-CPP Pilot Study. Draft Report. University of California, Berkeley. March 2006. 